\title{
UNESP
}

Faculdade de Engenharia do Campus de Guaratinguetá

Guaratinguetá

2010 
RENATA HELENA DA SILVA MOREIRA

\section{Análise do comportamento biomecânico de fios ortodônticos após tratamento de superfície}

Dissertação apresentada à Faculdade de Engenharia do Campus de Guaratinguetá, Universidade Estadual Paulista, para a obtenção do título de Mestre em Engenharia Mecânica na área de Materiais.

Orientadora: Profa. Dra. Ana Paula Rosifini Alves Claro 


\begin{tabular}{|l}
\hline M838a \\
Moreira, Renata Helena da Silva \\
Análise do comportamento biomecânico de fios ortodônticos após \\
tratamento de superfície. / Renata Helena da Silva Moreira - \\
Guaratinguetá : [s.n], 2010. \\
106f. : il. \\
Bibliografia: f. 77-86 \\
Dissertação (Mestrado) - Universidade Estadual Paulista, Faculdade de \\
Engenharia de Guaratinguetá, 2010. \\
Orientador: Prof ${ }^{a}$ Dr $^{\text {a }}$ Ana Paula Rosifini Alves Claro \\
1. Fios ortodônticos I. Título \\
CDU 612.766 \\
\hline
\end{tabular}




\section{unesp}

ESTA DISSERTAÇÃO FOI JULGADA ADEQUADA PARA A OBTENÇÃO DO TITUULO DE "MESTRE EM ENGENHARIA MECÂNICA"

\section{PROGRAMA: ENGENHARIA MECÁNICA} ÁREA: MATERIAIS

APROVADA EM SUA FORMA FINAL PELO PROGRAMA dE PÓS-GRADUAÇÃo

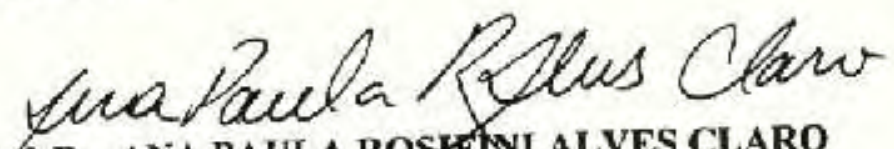

Prof. Dr. ANA PAULA ROSH MII ALVES CLARO

Orientador / Unesp-Fet

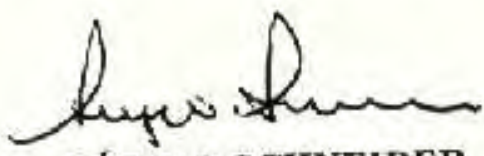

Prof. Dr. SÉRGIO SCHNEIDER EELUSP

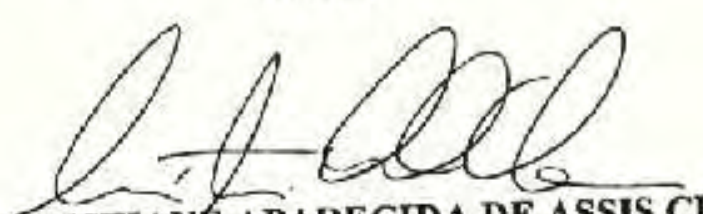

Prof. Dr. CRISTIADÉ APARECIDA DE ASSIS CLARO UNITAU 


\section{DADOS CURRICULARES}

\section{RENATA HELENA DA SILVA MOREIRA}

NASCIMENTO 24.03.1970 - São Paulo / SP

FILIAÇÃO Romeu da Silva Moreira

Maria Helena da Silva Moreira

1988/1991 Curso de Graduação em Odontologia

Universidade Taubaté - UNITAU

2000/2002 Curso de Especialização em Ortodontia

e Ortopedia Facial na Universidade

Camilo Castelo Branco - Unicastelo

2007/2010 Curso de Pós-Graduação em Engenharia Mecânica, Nível de Mestrado, na Faculdade de Engenharia do Campus de Guaratinguetá da Universidade Estadual Paulista/ UNESP 


\section{DEDICATÓRIA}

Esta dissertação é dedicada aos meus pais, Romeu e Maria Helena, pelo carinho e apoio em todos os momentos de minha vida.

Aos meus filhos, Yasmin e Gabriel, que pelo simples fato de existirem, me incentiva a lutar e a vencer,

Aos meus irmãos, Roberta e Ricardo, que sempre me incentivaram em meus estudos. 


\section{AGRADECIMENTOS}

Em primeiro lugar agradeço a Deus, pela minha vida, minha inteligência, e por ter me iluminado na concretização deste trabalho.

À minha orientadora $\operatorname{Prof}^{\mathrm{a}} \operatorname{Dr}^{\mathrm{a}}$ Ana Paula Rosifini Alves Claro, pelo incentivo, dedicação e amizade.

Ao Departamento de Materiais e Tecnologia da Engenharia Mecânica da FEG -UNESP, pelas informações e apoio recebidos, tornando possível a realização dessa dissertação de Mestrado.

Aos professores, Dr. Sérgio Schneider e Dra. Cristiane Aparecida de Assis Claro, pela participação no exame de qualificação e argüição.

Ao Prof. Dr. Sérgio Schneider e Prof. Dra. Sandra G. Schneider pela dedicação na realização dos ensaios de flexão em três pontos.

Ao aluno de graduação Leandro Martins pela dedicação e auxílio nos ensaios de flexão em três pontos.

A Profa. Nazir Marins pela colaboração na realização deste estudo e apoio na realização da Espectroscopia de Raman e Perfilometria.

Ao professor do Departamento de Física, Dr. Rogério Mota pelo apoio na realização deste trabalho.

Ao professor do Departamento de Física, Dr. Konstantin Georgiev Kostov pelo apoio no desenvolvimento deste trabalho.

Ao aluno de Mestrado Alessandro Luís Ribeiro dos Santos pelo apoio e colaboração nas medidas do ângulo de contato e energia de superfície.

Ao Dr. João Paulo Barros Machado do Laboratório de Sensores e Materiais - LAS - do Instituto de Pesquisa Espacial (INPE) em São José dos Campos, que propiciou a realização das análises de Espectroscopia de Raman e Perfilometria.

Aos funcionários da Seção de Pós-Graduação da FEG/UNESP, Regina Célia Galvão Faria Alves, Elisa Mara de Carvalho Nunes, Sidney Eustáquio 
Ramos Rabelo, Maria Cristina Silva de Oliva, Adriano Martins de Almeida pela atenção no atendimento.

À secretária do Departamento de Materiais e Tecnologia Maria Aparecida R. Vasconcelos pela gentileza no atendimento.

A minha família, que direta e indiretamente contribuiu para que meu trabalho fosse possível de ser realizado. 
DAS UTOPIAS

Se as coisas são inatingíveis... ora! Não é motivo para não querê-las... Que tristes os caminhos, se não fora A presença distante das estrelas! 
MOREIRA, R.H.S. Análise do comportamento biomecânico de fios ortodônticos após tratamento de superfície. 2010, Dissertação (Mestrado em Engenharia Mecânica) - Faculdade de Engenharia, Campus de Guaratinguetá, São Paulo, Guaratinguetá, 2010.

\section{RESUMO}

Fios ortodônticos são fabricados com uma série de materiais como aço inoxidável, metais, cerâmicas e polímeros. No meio bucal, eles estão sujeitos a fluídos corrosivos e variação de $\mathrm{pH}$ podendo levar a liberação de íons níquel nos tecidos e fluídos corpóreos. Neste estudo in vitro, filmes de carbono amorfo hidrogenado A-C:H foram depositados em fios ortodônticos empregando a técnica de PECVD para inibir a liberação de íons. $\mathrm{O}$ arranjo estrutural dos fios foi estudado a partir de Espectroscopia Raman e a molhabilidade avaliada medindo-se o ângulo de contato da superfície. Para avaliar a liberação de íons, os arcos ortodônticos (com e sem filme) foram montados em modelos confeccionados com resina e imersos em solução fisiológica a $37^{\circ} \mathrm{C}$ por 30 dias. Durante o tempo de imersão as amostras foram lavadas e/ou imersas em colutórios diariamente. Espectrofotometria de absorção atômica foi usada para medir a liberação de elementos a partir de amostras. Os resultados mostraram que o revestimento previne a liberação de $\mathrm{Ni}$ dos fios. O tratamento de superfície alterou o comportamento mecânico dos fios avaliados.

PALAVRAS-CHAVE: Fios ortodônticos. NiTi. Tratamento de superfície. Filme A:C-H . 


\title{
MOREIRA, R.H.S. Analysis of biomechanical behaviour of orthodontics
} wires after surface treatment. 2010, Dissertation (Master in Science) - College of Engeneering, Campus of Guaratinguetá, São Paulo State University, Guaratinguetá, 2010.

\begin{abstract}
Orthodontics wires are made from a variety of metals such as stainless steel, metals, ceramics and polymers. In oral environment, they are subjected to aggressive fluids and $\mathrm{pH}$ variation that can lead to nickel ions releasing to body tissues and fluids. In this in vitro study, A:C-H films were deposited on orthodontics wires by radio-frequency plasma-enhanced chemical vapour deposition (PECVD) from inhibited nickel ions release. The structural arrangement of films was probed by Raman spectroscopy and contact angle measurements were carried out in order to evaluate the wettability of surface. To evaluate ions release, orthodontics wires (coated and uncoated) were mounted in resin mould and immersed inn physiological serum for 30 days at $37^{\circ} \mathrm{C}$. During the immersion time the samples were brushed and/or immersed in mouthwashes daily. Atomic absorption spectrophotometry was used to measure the release of elements from the samples in solution. Results showed that the coating prevents Ni release of orthodontics wires. Surface treatment change mechanical properties of orthodontics wires.
\end{abstract}

KEYWORDS: Orthodontics wires. NiTi. Surface treatment. A:C-H films. 


\section{LISTA DE FIGURAS}

FIGURA 1 Componentes do aparelho ortodôntico....................................... 19

FIGURA 2 Evolução clínica demonstrando a utilização dos fios de níquel-titânio (a) inicio do alinhamento e nivelamento, (b) e

(c) fase intermediária e (d) fase final

FIGURA 3 Curvas demonstrativas das propriedades de um fio de NiTi....

FIGURA 4 Representação esquemática da transformação austenita/martensita: (a) estrutura totalmente austenítica;(b) interface austenita/martensita; (c) avanço da interface: cada camada de átomos é deslocada somente uma pequena distância; (d) estrutura totalmente martensítica

FIGURA 5 Dois mecanismos de acomodação da forma devido ao cisalhamento atômico da transformação martensitica: (a) acomodação por deslizamento (irreversível); (b) acomodação por maclagem (reversível)

FIGURA 6 Microscopia óptica de fios NiTi comerciais: (a) matriz totalmente martensitica; (b) fase martensitica mais grosseira; (c) microestrutura predominantemenete martensitica com pequenas regiões austeniticas; (d) regiões alternadas de martensita e austenita

FIGURA 7 Diagrama de uma liga NiTi com efeito de memória de forma.

FIGURA 8 Efeito superelástico nas ligas memória de forma: (a) austenita; (b) inicio da transformação martensítica; (c) martensita; (d) deformação elástica da martensita; (e) transformação reversa.

FIGURA 9 Diagrama ternário de fases do DLC.......................................... 36

FIGURA 10 Espectros Raman de filmes de diamante excitados com três 
diferentes comprimentos de onda.

FIGURA 11 Espectros Raman de filmes de grafite excitados com três diferentes comprimentos de onda

FIGURA 12 Espectros Raman de filmes de DLC excitados com três diferentes comprimentos de onda............................................ 41

FIGURA 13 Esquema ilustrativo do ângulo de contato............................... 41

FIGURA 14 Fluxograma demonstrativo da metodologia empregada........ 43

FIGURA 15 Equipamentos utilizados para a deposição filmes DLC........ 44

FIGURA 16 Diagrama de blocos do sistema de deposição de filmes

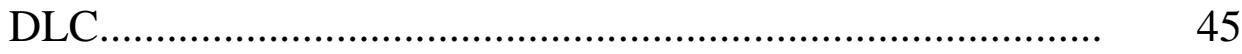

FIGURA 17 Deposição de filme DLC nas amostras de NiTi....................... 49

FIGURA 18 Perfilômetro Tencor Alpha Step 500....................................... 49

FIGURA 19 Esquema ilustrativo do degrau para medida da espessura do filme de DLC....................................................................... 50

FIGURA 20 Goniômetro automatizado (Ramé-Hard-modelo 100-00)... 51

FIGURA 21 Deposição da gota para cálculo do ângulo de contato.......... 52

FIGURA 22 Imagem da gota obtida pelo programa de computador para

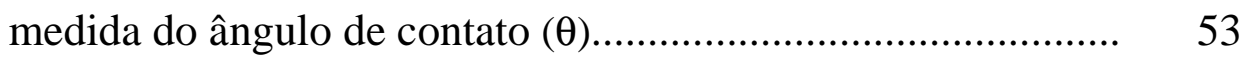

FIGURA 23 (a) Modelo em resina e instrumental utilizado para fixação arco/braquete; (b) detalhe do modelo com arco........................ 53

FIGURA 24 Modelo acondicionado em recipiente com soro fisiológico..... 54

FIGURA 25 Aquário com recipientes simulando meio bucal........................ 55

FIGURA 26 Equipamento EMIC, Modelo EE 050, com célula de carga de $20 \mathrm{~N}$ utilizado para o ensaio de flexão três pontos.................... 56

FIGURA 27 Detalhamento do sistema para teste de flexão em três pontos 57

FIGURA 28 Vista superior do sistema para teste de flexão em três pontos em amostras de fios de NiTi................................................. 58

FIGURA 29 Ensaio de flexão em três pontos em amostras NiTi(a) e (b).. $\quad 58$

FIGURA 30 Equipamento para o ensaio de flexão em três pontos para fios 
FIGURA 31 a) Ensaio de flexão em três pontos realizada em amostra de NiTi termoativada. (b) Detalhe do ensaio de flexão em três pontos em amostra NiTi termoativada 60

FIGURA 32 Curva representativa do ensaio de flexão em três pontos.......

FIGURA 33 Espectro Raman obtido a partir de um filme de carbono amorfo hidrogenado (a-C:H)

FIGURA 34 Imagem da gota de água sobre o substrato com filme de a$\mathrm{C}: \mathrm{H}$.......

FIGURA 35 Liberação de íons níquel para as duas ligas avaliadas.

FIGURA 36 Curva força x deflexão de calibração obtida a partir do ensaio de flexão empregando-se deflectômetro eletrônico da EMIC

FIGURA 37 Curva força x deflexão da liga NiTi com e sem tratamento de superfície

FIGURA 38 Curva força x deflexão da liga NiTi termoativada com e sem tratamento de superfície.

FIGURA 39 Curva tensão x deformação da liga NiTi superelástica com e sem DLC.

FIGURA 40 Curva tensão x deformação da liga NiTi termoativada com e sem

DLC 


\section{LISTA DE QUADROS}

QUADRO 1 Valores do módulo de elasticidade (E) de ligas metálicas para fios de mesmo diâmetro

QUADRO 2 Comparação das propriedades de carbonos amorfos com diamante, grafite, $\mathrm{C}_{60}$ e polietileno 


\section{LISTA DE TABELAS}

TABELA 1 Grupos e condições de deposição.............................................. 48

TABELA 2 Posição, largura e intensidade das bandas D e $\mathrm{G}$ do espectro

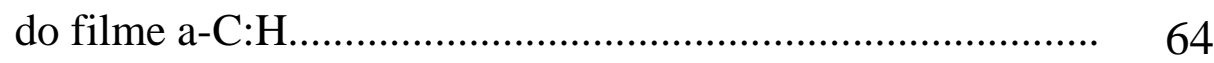

TABELA $3 \quad$ Valores médios do ângulo de contato ...................................... 65

TABELA 4 Valores das forças de desativação em função para diferentes níveis de deflexão..................................................................

TABELA 5 Valores médios de tensões (MPa) em função para diferentes níveis de deflexão.................................................... 73 


\section{LISTA DE ABREVIATURAS}

\begin{tabular}{|c|c|}
\hline NiTi & Liga de níquel-titânio \\
\hline DLC & Diamond-Like-Carbon \\
\hline PECVD & Deposição química por plasma de rádio frequência \\
\hline TMA & Liga de titânio molibdênio \\
\hline $\mathrm{TiNb}$ & Liga titânio-nióbio \\
\hline $\mathrm{NiTiCu}$ & Liga Níquel-titânio-cobre \\
\hline AFM & Microscopia atômica de força \\
\hline SEM & Microscopia eletrônica de varredura \\
\hline $\mathrm{M}_{\mathrm{s}}$ & Temperatura do início da transformação martensítica \\
\hline $\mathrm{M}_{\mathrm{f}}$ & Temperatura final da transformação martensítica \\
\hline $\mathrm{A}_{\mathrm{s}}$ & Temperatura do início da transformação austenítica \\
\hline$A_{f}$ & Temperatura final da transformação austenítica \\
\hline $\mathrm{M}_{\mathrm{ms}}$ & Máxima temperatura para formação da fase martensita superelástica \\
\hline $\mathrm{M}_{\mathrm{d}}$ & Máxima temperatura na qual a martensita pode ser formada \\
\hline $\mathrm{H}$ & Histerese \\
\hline SME & Efeito memória de forma \\
\hline SMA & Transformação martensítica induzida por tensão \\
\hline TTR & Intervalo de temperatura de transição \\
\hline $\mathrm{a}-\mathrm{C}: \mathrm{H}$ & Carbono amorfo hidrogenado \\
\hline $\mathrm{nm}$ & nanômetro \\
\hline $\mathrm{N}$ & Newton \\
\hline $\mathrm{MPa}$ & megapascal \\
\hline $\mathrm{h}$ & Altura $h$ \\
\hline ADA & American Dental Association \\
\hline MOD & Com modificação (DLC) \\
\hline
\end{tabular}




\section{SUMÁRIO}

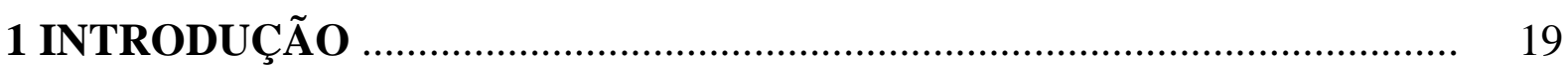

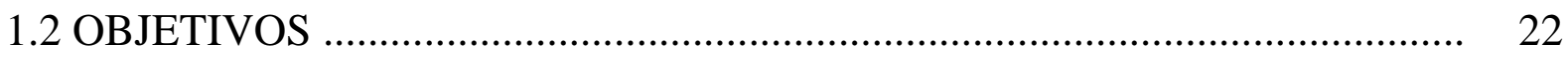

1.3 ESTRUTURA DA DISSERTAÇÃO ………………................................ 23

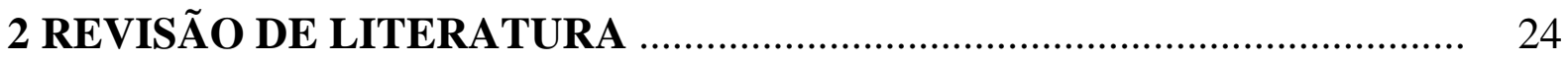

2.1 CONSIDERAÇÃO GERAIS .................................................................... 24

2.2 PROPRIEDADES DAS LIGAS DE NÍQUEL-TITÂNIO_.................................. 24

2.2.1 Efeito de memória de forma ou memória de forma térmica..................... 25

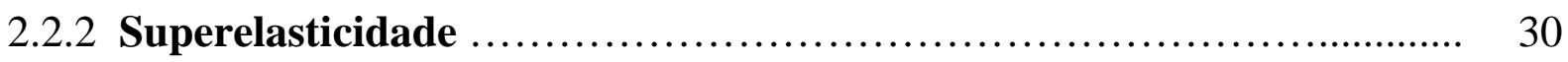

2.2.3 Biocompatibilidade e citotoxicidade das ligas Níquel-Titânio.................. 31

2.3 TRATAMENTOS DE SUPERFÍCIE ..................................................... 34

2.3.1 Técnicas de deposição............................................................................. 37

2.3.2 Caracterização dos filmes de DLC....................................................... 39

3 MATERIAIS E MÉTODOS …............................................ 43

3.1 TRATAMENTO DE SUPERFÍCIE ............................................................. 44

3.1.1 Processo de deposição dos filmes DLC ..................................................... 44

3.1.2 Limpeza dos substratos ……………………................................. 46

3.1.3 Condições de deposição ............................................................................. 46

3.2 CARACTERIZAÇÃO DOS FILMES ...................................................... 49

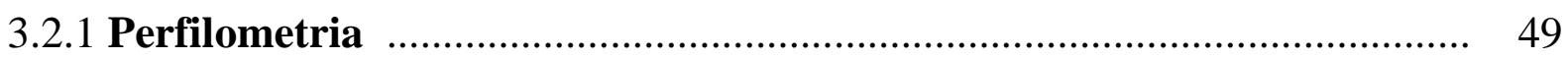

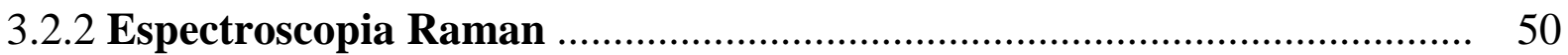

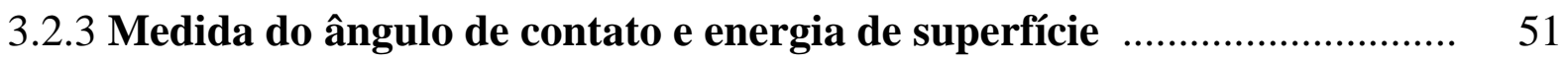

3.3 ENSAIO DE ESCOVAÇÃO .................................................................. 53

3.3.1 Espectrôfotometro de absorção atômica ……………………………....... 55

3.4 ENSAIO DE FLEXÃO EM TRÊS PONTOS ………................................... 56

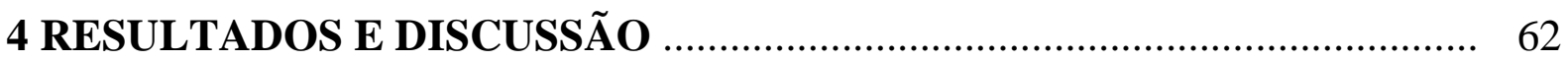

4.1. CARACTERIZAÇÃO DOS FILMES....................................................... 62

4.1.1 Perfilometria ……………........................................................... 62 
4.1.2 Espectroscopia Raman......................................................................... 62

4..1.3 Medida do ângulo de contato e energia de superfície ............................. 65

4.1.4 Ensaio de escovação ............................................................................... 66

4.1.5 Ensaio de flexão em três pontos ............................................................... 67

4.1.5.1 Calibração do sistema de medidas........................................................ 67

4.1.5.2 Resultados dos ensaios de flexão........................................................ 68

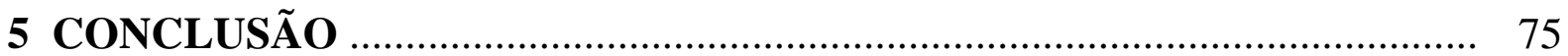

REFERÊNCIAS BIBLIOGRÁFICAS.............................................................. 77

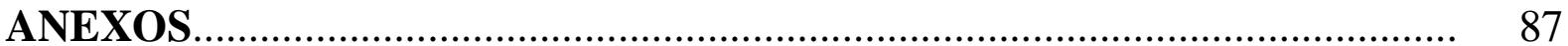




\section{INTRODUÇÃO}

$\mathrm{Na}$ Ortodontia, é comum o emprego de materiais metálicos (ligas metálicas) e não metálicos (cerâmicas, compósitos e policarbonatos) na confecção de aparelhos corretivos fixos (GURGEL; RAMOS; KERR, 2001) formados por bandas, braquetes, fios ortodônticos, amarrilhos e ligaduras (Figura 1), para a correção e posicionamento de dentes e ossos maxilares (HENRIQUES; MACHADO; HAYASAKI, 2002).

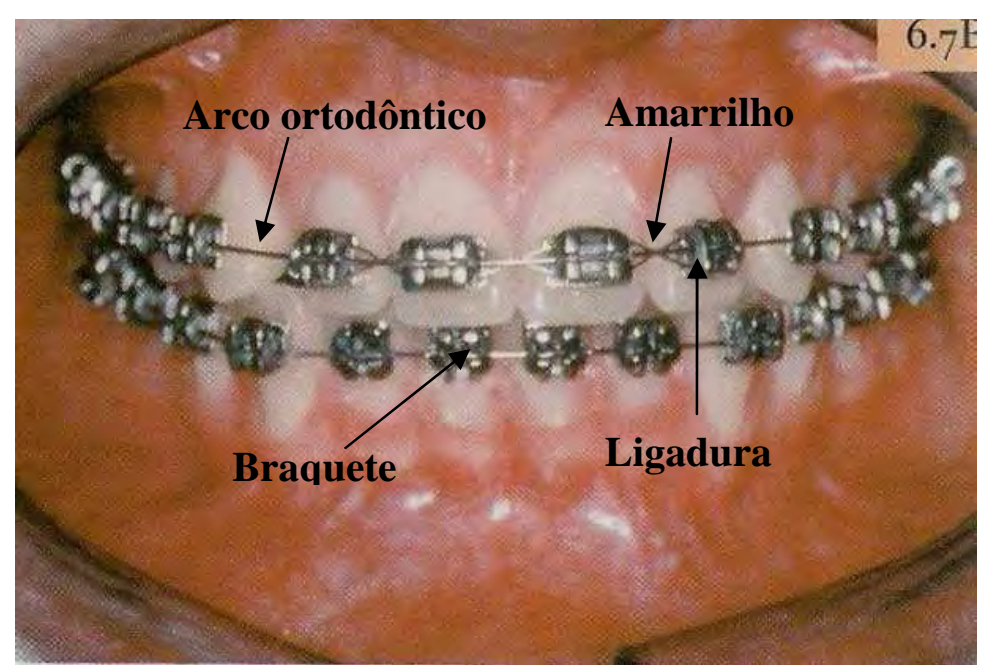

Figura 1 - Componentes do aparelho ortodôntico (HENRIQUES; MACHADO; HAYASAKI, 2002)

As ligas metálicas são as mais empregadas para a confecção de fios ortodônticos devido às suas propriedades mecânicas (FERREIRA, 2005). Inicialmente, os fios ortodônticos eram confeccionados com materiais nobres como ouro, platina, paládio, sendo posteriormente substituídos por aço inoxidável austenítico. No início da década de 60, foram desenvolvidas as ligas a base de cromo-cobalto conhecida como Elgiloy (Rocky Mountain Orthodontics) que comparadas ao aço inoxidável apresentavam propriedades semelhantes. Os fios de cromo-cobalto têm como característica maior formabilidade, pois é fabricado em quatro têmperas com variação decrescente sendo que o azul representa a mais maleável, seguida pelo amarelo (dúctil), verde (semiresiliente) e vermelho (resiliente) (GURGEL; RAMOS; KERR, 2001).

No início dos anos 60, Willian Buehler desenvolveu uma liga que ficou conhecida como Nitinol (níquel, titânio e NOL - Naval Ordinance Laboratory) 
composta por $55 \%$ p de níquel e $45 \%$ p de titânio. Sua introdução na Ortodontia ocorreu na década de 1970, o que trouxe mudanças irreversíveis nas técnicas de tratamento corretivo, tanto para o paciente quanto para o profissional, pois permitiu grandes ativações com o uso de forças leves e constantes (GHERSEL, 2005).

A utilização de fios de $\mathrm{NiTi}$ nas fases iniciais do tratamento ortodôntico simplifica esta etapa, pois não há necessidade de troca constante de arcos de nivelamento, como ocorre com os fios de aço inoxidável, aumentando assim a rigidez (ACKERMAN et al., 1978; FERREIRA, 2005). Sabe-se que forças leves contribuem para a redução de reabsorção radicular e diminuição do tempo de tratamento ortodôntico como demonstrado na figura 2.
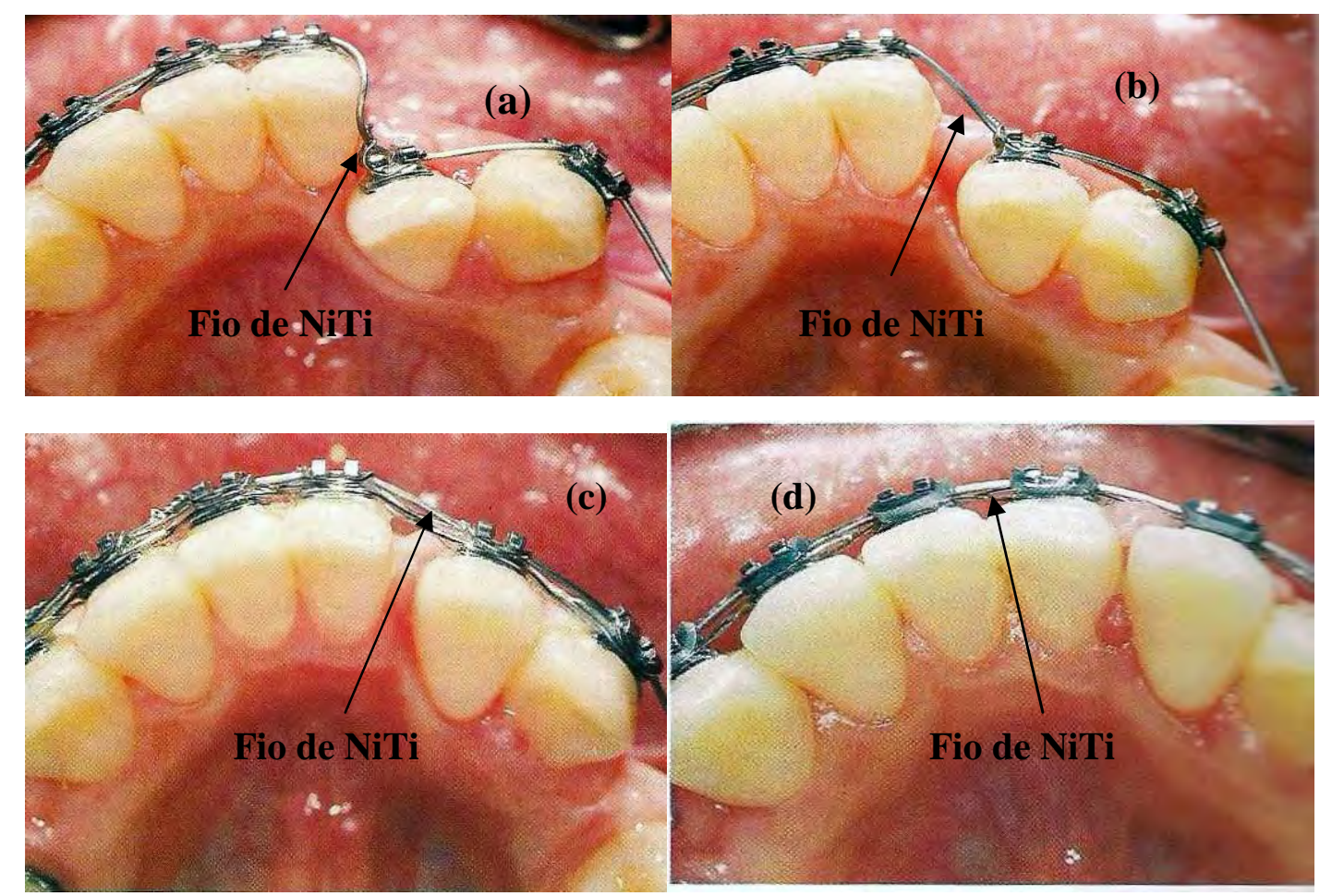

Figura 2- Evolução clínica demonstrando a utilização dos fios de níquel-titânio: (a) inicio do alinhamento e nivelamento, (b) e (c) fase intermediária e (d) fase final (FERREIRA, 2005)

A liga beta titânio TMA (Titanium Molybdenum Alloy), contendo 79\% titânio, $11 \%$ molibdênio, 6\% zircônio e 4\% estanho, foi introduzida na Ortodontia em 1979. Possui módulo de elasticidade menor que o aço inoxidável e maior que a liga de níquel-titânio (Quadro 1), exibindo efeito memória de forma, excelente resistência à corrosão, podendo ser soldada por caldeamento. As forças geradas por estes fios são 
intermediárias entre o aço inoxidável e o Nitinol, os fios aceitam dobras e são indicados principalmente para pacientes com hipersensibilidade ao níquel sendo de grande utilidade nas fases intermediária e final do tratamento ortodôntico. (KANEKO et al., 2003; ANDRADE; SATO; KOZEL, 2007). No entanto, a principal desvantagem desta liga é o alto atrito, sendo oito vezes maior que o aço (GURGEL; RAMOS; KERR, 2001; KUSY, 1997).

Quadro 1 - Valores do módulo de elasticidade (E) de ligas metálicas para fios de mesmo diâmetro (GURGEL; RAMOS; KERR, 2001; ARRUDA,2002)

\begin{tabular}{|c|c|c|}
\hline LIGA & $\begin{array}{c}\text { Módulo de elasticidade } \\
\text { E }(\mathbf{G P a})\end{array}$ & Rigidez relativa ao aço \\
\hline Aço inoxidável & $189-205 \mathrm{GPa}$ & 1,00 \\
Elgiloy & $190-200 \mathrm{GPa}$ & 0,97 \\
Beta-titânio & $72 \mathrm{GPa}$ & 0,36 \\
M-NiTi & $33,8 \mathrm{GPa}$ & 0,17 \\
\hline
\end{tabular}

As ligas de níquel-titânio podem ser classificadas em estáveis - ativas de acordo com o seu comportamento mecânico. Uma das desvantagens dos fios de níquel-titânio é a baixa tenacidade permitindo mínimas dobras (FERREIRA, 2005). Dentro do grupo das ligas níquel-titânio estáveis, temos os fios de multifilamentos que apresentam baixo nível de forças e são ideais para estágios iniciais do tratamento ortodôntico (ANDRADE; SATO; KOZEL, 2007) principalmente em pacientes com perda óssea acentuada e também para a fase de intercuspidação (GURGEL; RAMOS; KERR, 2001).

Na década de 1990 foram desenvolvidos os fios de níquel-titânio ativo também conhecido como termoativado ou superelástico. Esses materiais possuem diferentes temperaturas de transição indicando a ação em intervalos de forças previamente estabelecidos, possibilitando seu uso clínico quando solicitada maior ou menor rigidez. Os fios Ni-Ti-Cu $\left(27^{\circ} \mathrm{C}, 35^{\circ} \mathrm{C}\right.$ e $\left.40^{\circ} \mathrm{C}\right)$ diferenciam-se segundo a temperatura em que o material encontra-se totalmente na fase austenítica e quanto maior a temperatura da 
reversão martensítica, mais maleável torna-se o fio e menor a força exercida sobre os dentes (GURGEL; RAMOS; KERR, 2001).

Posteriormente foram desenvolvidas as ligas de titânio-nióbio com propriedades mecânicas semelhantes ao TMA, mas com menor rigidez sendo aplicadas como fios de finalização (ANDRADE; SATO; KOZEL, 2007).

De um modo geral, as ligas a base de titânio (NiTi, TMA, TiNb e CuNiTi) possuem elevada resistência a corrosão (SCHIFF; GROSGOGEAT; DALARD, 2004) quando comparadas a liberação de íons de outras ligas metálicas (RAHILLY E PRICE, 2003) devido à formação de um filme composto por óxido de titânio $\left(\mathrm{TiO}_{2}\right)$ em sua superfície (KANEKO et al., 2004).

A quebra da camada passiva pode levar a liberação de íons de níquel (STAFFOLANI et al.,1999) que está associado à dermatite de contato, com casos de reações alérgicas e processos patológicos (ELIADES E ATHANASIOU, 2002; EL MEDAWAR et al., 2002; ELIADES et al., 2004). A prescrição do uso tópico de flúor gel acidulado em pacientes portando aparelhos ortodônticos com fios de níquel-titânio deve ser criteriosa, pois o meio bucal torna-se extremamente agressivo ao material, ocorrendo dissolução intensa no período de aplicação devido a acidez do meio bucal, induzindo a liberação de íons de níquel (BUCCI; CÂNDIDO; GOMES, 2003).

Os tratamentos superficiais são uma alternativa viável para minimizar a liberação de íons associados ao processo de corrosão devido à formação de filmes finos com maior resistência ao desgaste. De acordo com a literatura, o uso de filmes DLC - Diamond-Like-carbon Film em arcos ortodônticos de níquel-titânio apresentou excelente adesão mecânica durante escovação e melhorou a resistência a corrosão destes arcos, mantendo suas propriedades mecânicas e proporcionando boa compatibilidade em meio bucal (KOBAYASHI et al, 2005).

\subsection{OBJETIVOS}

O objetivo deste estudo foi avaliar a liberação de íons em arcos ortodônticos fabricados com as ligas níquel-titânio superelásticos e termoativados, a partir de tratamento de superfície por DLC (Diamond-Like-Carbon) empregando a técnica 
PECVD (deposição química por plasma de rádio freqüência) e verificar a influência deste filmes nas propriedades mecânicas desses materiais.

\subsection{ESTRUTURA DA DISSERTAÇÃO}

Esta dissertação é constituída por seis capítulos e pelas referências bibliográficas, tendo conteúdo distribuído da seguinte forma:

Capítulo 1, Introdução: expõe aspectos gerais sobre a dissertação, proposta do trabalho, justificativa, objetivos e a estrutura da dissertação.

Capítulo 2, Revisão da Literatura contém: Considerações Gerais sobre a liga de $\mathrm{NiTi}$, propriedades desta liga, biocompatibilidade e citotoxicidade, deposição de filmes finos de a-C:H, ensaio de flexão em três pontos.

Capítulo 3, Materiais e Métodos: descreve a metodologia utilizada, a confecção do corpo de prova, a deposição do filme de a-C:H, caracterização do filme, análise de absorção atômica, teste de flexão em três pontos.

Capítulo 4, Resultados e Discussões: apresentação detalhada dos resultados alcançados nos experimentos realizados no trabalho e suas respectivas análises, em confronto com outros autores e trabalhos revisados na literatura.

Capítulo 5, Conclusões: são expostas as conclusões obtidas a partir da avaliação criteriosa dos resultados encontrados neste estudo. 


\section{REVISÃO DE LITERATURA}

\subsection{CONSIDERAÇÕES GERAIS}

A liga de níquel-titânio, com composição $55 \%$ p de níquel e $45 \%$ p de titânio, conhecida como Nitinol (Nickel Titanium Naval Ordinance Laboratory) foi desenvolvida em 1962, pelo U.S. Naval Ordinance Laboratory. Os pesquisadores buscavam um material não magnético, resistente à corrosão, de elevada dureza, para ser usado na confecção de ferramentas e armas de mão (PÉRTILE, 2005). A introdução dos fios de níquel-titânio na Ortodontia iniciouse na década de 1970, por Andreasen (CHEN et al, 1992) e a partir da década de 1990 produtos de níquel-titânio passaram a ser comercializados e empregados também na medicina devido a sua superelasticidade e ao efeito memória de forma, propriedades completamente novas na época em comparação a ligas metálicas convencionais (RYHÄNEN, 1999).

$\mathrm{Na}$ Ortodontia as ligas de níquel-titânio são empregadas na fabricação de fios ortodônticos podendo ser divididas em dois tipos, em função da composição química da liga e do processo de fabricação, apresentando os fenômenos de memória de forma (arcos termoativados - liga martensítica ativa) e pseudoelasticidade (arcos superelásticos - liga austenítica ativa) que de acordo com alguns autores são de interesse para a área ortodôntica (MULLINS; BAGHY; NORMAN, 1996; OLTJEN et al., 1997; BRITO et al., 2004)

Vários parâmetros, como a composição da liga, procedimentos de recozimento e condições de carregamento, podem melhorar o efeito de memória da forma (ERBSTOESZER et al, 2000).

\subsection{PROPRIEDADES DAS LIGAS DE NÍQUEL-TITÂNIO}

É bem conhecido que as ligas memória de forma não exibem apenas o efeito memória de forma, mas também o comportamento pseudoelástico ou superelasticidade. 
Dessa forma, as propriedades dessas ligas são derivadas das mudanças microestruturais que podem ocorrer devido à aplicação de tensão ou devido à variação de temperatura. A transformação de fase induzida pela tensão permite que uma deformação de $8 \%$ possa totalmente ser recuperada quando o material for descarregado por meio de uma transformação de fase reversa (superelasticidade). $\mathrm{O}$ termo memória de forma é derivado da habilidade da liga em lembrar uma forma pré-determinada no aquecimento (EVANS et al, 2008) e na solicitação mecânica.

A liga NiTi pode apresentar duas características principais que seriam a superelasticidade e a memória de forma, relacionada ao efeito termoelástico. Essas características estão representadas na figura 3.

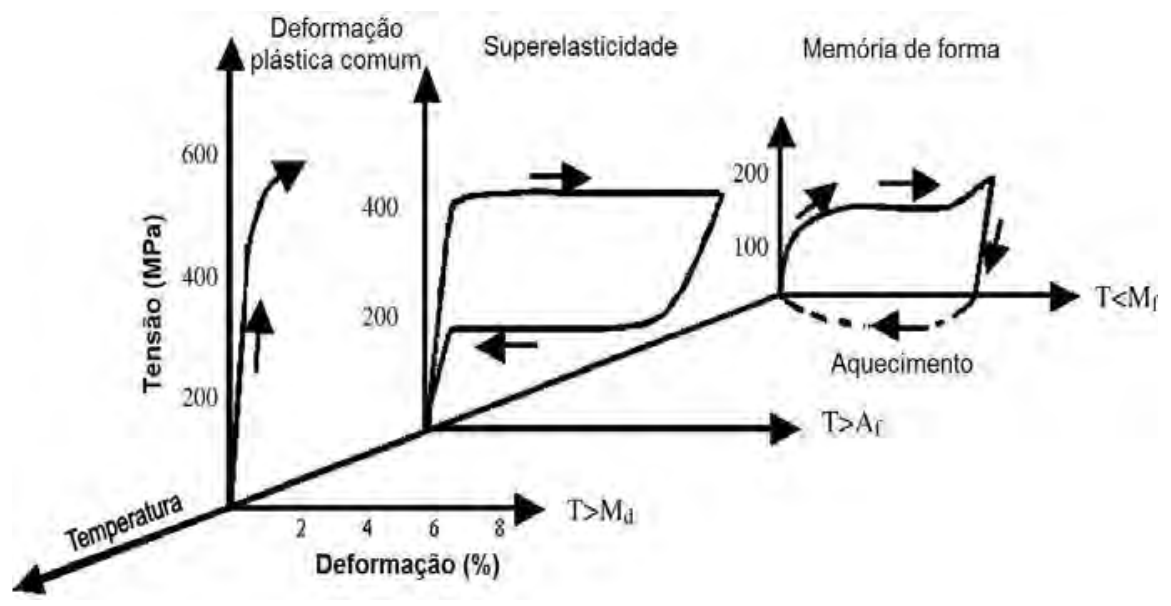

Figura 3 - Curvas demonstrativas das propriedades de um fio de NiTi (DAYANANDA e SUBBARAO, 2008)

\subsubsection{Efeito de memória de forma ou memória de forma térmica}

A liga Nitinol obtém seu efeito memória de forma a partir de uma mudança de fase reversível de uma microestrutura austenítica para martensítica. A temperatura de transformação é caracterizada por quatro temperaturas: $\mathrm{M}_{\mathrm{S}}$ e $\mathrm{M}_{\mathrm{f}}$ 
durante o resfriamento e $A_{S}$ e $A_{f}$ durante o aquecimento. $M_{S}$ e $M_{f}$ indicam as temperaturas nas quais ocorre o inicio e final da transformação da fase $\beta$ para martensita, enquanto $A_{S}$ e $A_{f}$ indicam as temperaturas onde ocorre a transformação reversa (HELSEN e BREME, 1998, SANTORO e BESHERS, 2000).

A transformação martensítica pode ser definida como uma transformação da rede envolvendo cisalhamento e movimento atômico cooperativo. A cinética de transformação possui dois tipos principais de transformação: atérmica e isotérmica. $\mathrm{Na}$ transformação atérmica durante o processo de nucleação do cristal não existe ativação térmica, dessa forma a quantidade da nova fase produzida depende apenas da temperatura e não do período de tempo gasto para uma dada temperatura. $\mathrm{Na}$ transformação isotérmica a quantidade de martensita formada é em função da temperatura isotérmica do tratamento térmico, e principalmente do tempo. Assim, as transformações isotérmicas se diferenciam das transformações atérmicas por serem dependentes do tempo. A fase martensítica é formada a partir da austenita sendo interpretada como uma sequiência de dois eventos: deformação de Bain e cisalhamento invariante da rede. A deformação de Bain ou deformação da rede causa a movimentação de todos os átomos, necessária para produzir uma estrutura nova a partir da velha. A figura 4a mostra esquematicamente a estrutura austenítica e a figura 4b-d a transformação martensítica (GIL e PLANELL, 1998).

A segunda parte na transformação martensítica é a acomodação: a martensita produzida pela deformação de Bain tem forma e volume diferentes da austenita circundante. A acomodação desta mudança na forma pode ocorrer por meio de dois mecanismos: deslizamento (Figura 5a) ou maclagem (Figura 5b). O deslizamento é um processo permanente e é um mecanismo de acomodação encontrado na maioria das estruturas martensíticas. A maclagem permite a acomodação de maneira reversível sendo o processo dominante em ligas com efeito de memória de forma (GIL e PLANELL, 1998). Na figura 6 é possível observar as micrografias ópticas encontradas na literatura, características destas fases.

Sob temperatura reduzida, estabelece-se a fase martensítica e, com o aumento da temperatura, ocorre novamente uma transformação progressiva para 
a fase austenítica. Com a redução da temperatura obtém novamente a martensita o que resulta em maior rigidez ao fio. Esse processo de transformação reversível, combinando tensão e temperatura, confere ao fio o efeito memória de forma. No processo de fabricação esses fios são moldados no formato desejado em altas temperaturas e, quando resfriados, podem ser dobrados com facilidade dentro dos braquetes. Quando esses fios atingem a temperatura da boca, eles tendem a voltar à forma dada na fabricação, gerando a ativação (MARINS e PROCACI, 2008).

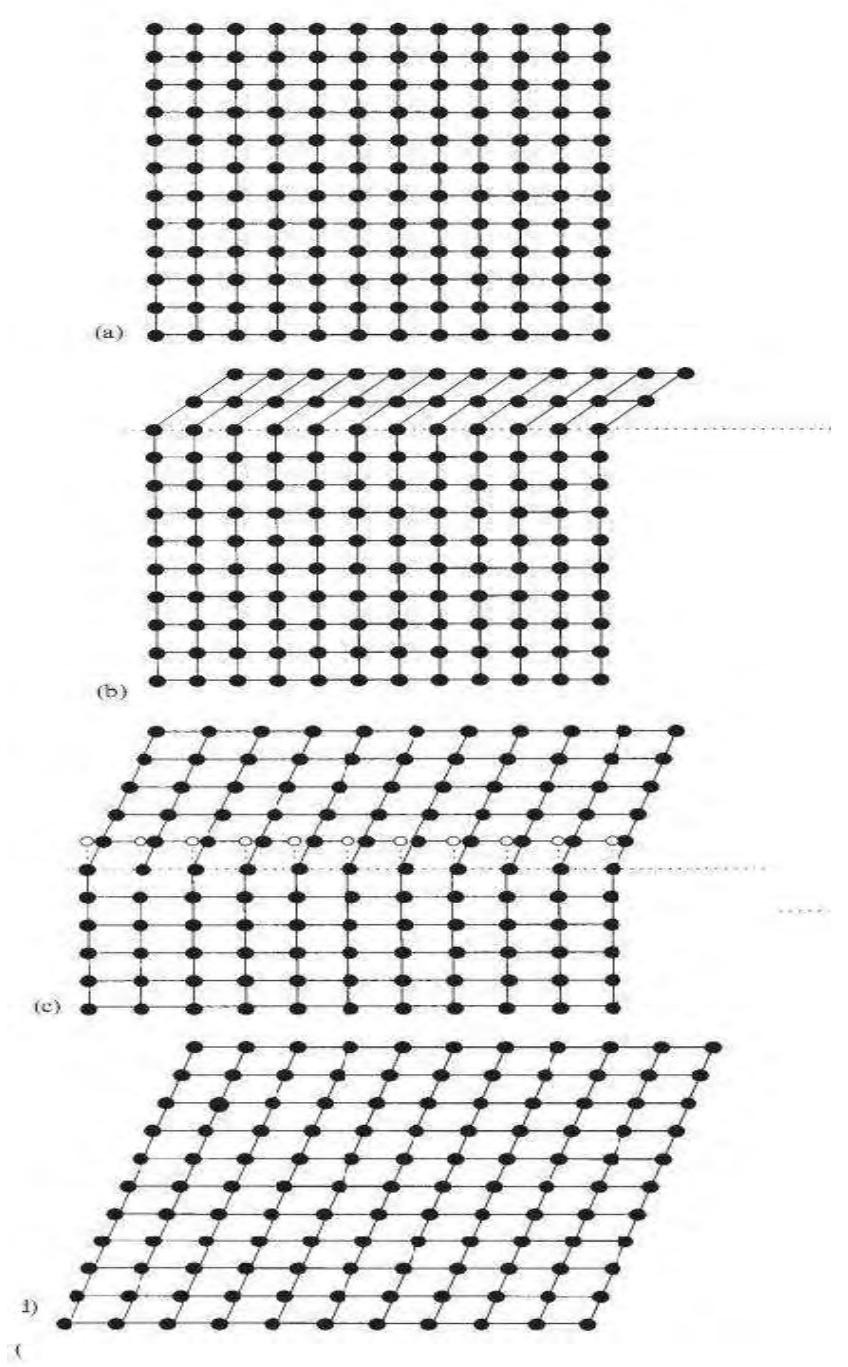

Figura 4- Representação esquemática da transformação austenita/martensita: (a) estrutura totalmente austenítica;(b) interface austenita/martensita; (c) avanço da interface: cada camada de átomos é deslocada somente uma pequena distância; (d) estrutura totalmente martensítica (GIL e PLANELL, 1998) 


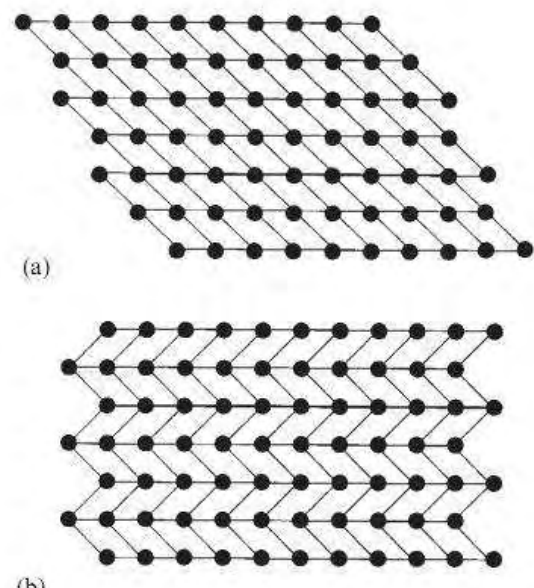

(b)

Figura 5 - Dois mecanismos de acomodação da forma devido ao cisalhamento atômico da transformação martensítica: (a) acomodação por deslizamento (irreversível); (b) acomodação por maclagem (reversível) (GIL e PLANELL, 1998)
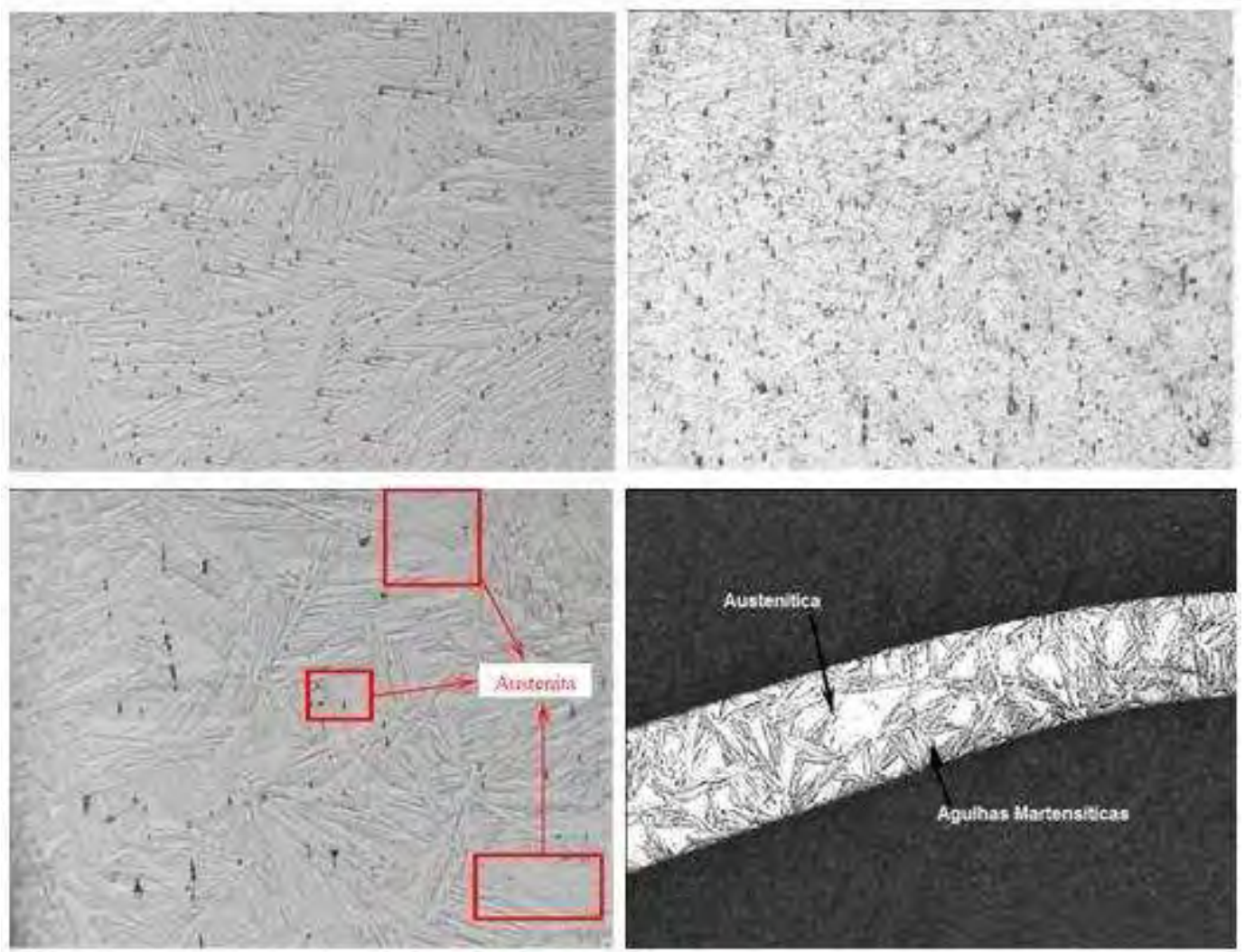

Figura 6 - Microscopia óptica de fios NiTi comerciais: (a) matriz totalmente martensítica; (b) fase martensítica mais grosseira; (c) microestrutura predominantemente martensítica com pequenas regiões austeníticas (GEROLDO; NUNURA; SANTOS, 2008) (d) regiões alternadas de martensita e austenita (JAFARI, ZEBARJAD E SAJJADI, 2008) 
A propriedade de memória de forma desses materiais é resultante da capacidade inerente de alterar a força de união, e também se relaciona à temperatura, por meio do intervalo de temperatura de transição (TTR), que varia dependendo da composição química da liga e de seu processamento (SANTORO e BESHERS, 2000). Os fios de níquel-titânio termicamente ativados podem ser encontrados em diferentes temperaturas de transição, indicando a ação em intervalos de força previamente estabelecidos (ROSANI, 2001). Isto possibilita o uso destes fios em diferentes situações clínicas, que podem requerer maior ou menor rigidez (GOUVEA, 2006). O comportamento desses fios pode ser melhor compreendido a partir da analise da figura 7.

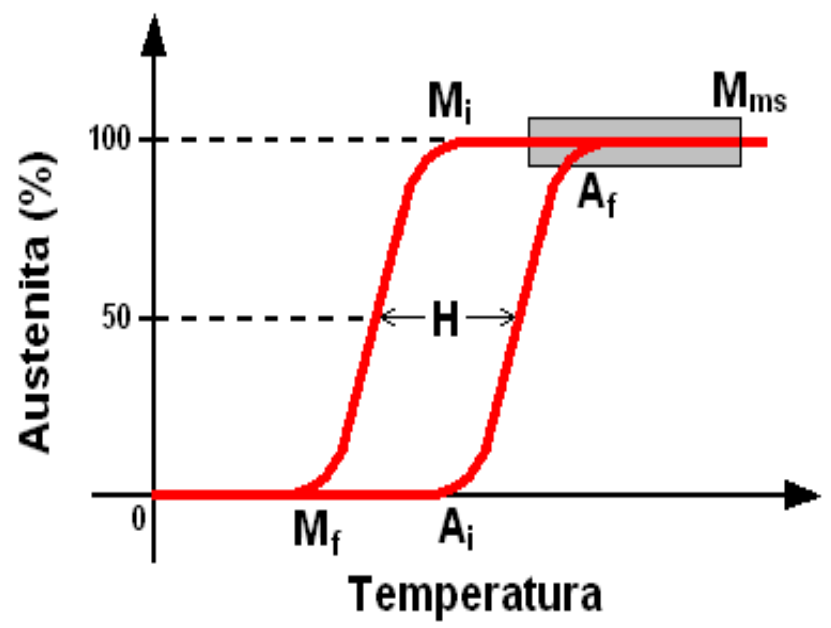

Figura 7 - Diagrama de uma liga NiTi com efeito de memória de forma

Mi e Mf são as temperaturas inicial e final, respectivamente, em que a martensita é formada; Mms é a máxima temperatura para a fase martensita superelástica; Ai e Af são as temperaturas inicial e final na qual a austenita é formada; $\mathrm{H}$ é a histerese. A austenita tem rigidez superior à martensita e maior capacidade de aplicar forças na desativação. A martensita, de característica mais dúctil, é conveniente na fase de ativação. Em aplicação na área ortodôntica, é interessante que Af esteja um pouco abaixo da temperatura do meio bucal. 


\subsubsection{Superelasticidade}

O efeito superelástico ocorre acima de $\mathrm{A}_{\mathrm{f}}$ e abaixo de $\mathrm{M}_{\mathrm{d}}$ conforme pode ser observado na figura 8. No ponto (a) o material é totalmente austenítico, sendo carregado elasticamente até o ponto (b) onde se inicia a transformação martensítica. No ponto (c) ocorre a transformação martensítica sendo no ponto (d) o carregamento elástico dessa fase. A partir do ponto (e) ocorre a transformação reversa da liga, ou seja, obtém-se a austenita novamente. $\mathrm{M}_{\mathrm{d}}$ é a temperatura mais alta na qual a martensita pode ser formada e está localizada acima de Af e abaixo da temperatura oral. A deflexão gera uma transformação martensítica localizada que é o fenômeno conhecido como transformação martensítica induzida por tensão - SIM (MELING e ODEGAARD, 2001).

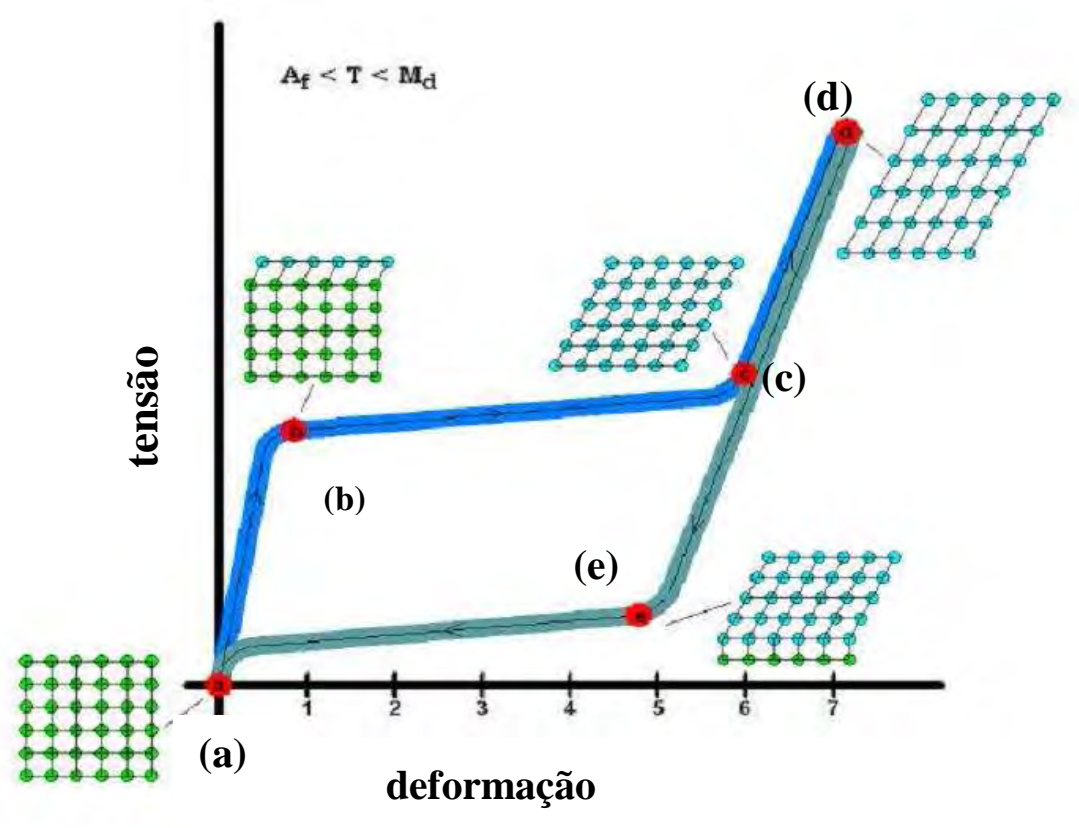

Figura 8 - Efeito superelástico nas ligas memória de forma: (a) austenita; (b) inicio da transformação martensítica; (c) martensita; (d) deformação elástica da martensita; (e) início da transformação reversa (ROBERTSON, 2006) 
O Nitinol pode apresentar até $11 \%$ de deformação enquanto a maioria dos metais pode apresentar apenas $1 \%$ de deformação elástica (ROBERTSON, 2006).

A histerese é o comportamento apresentado nos platôs de ativação e desativação em diferentes magnitudes de força. Histerese está associada ao atrito com a movimentação de maclas no contorno da martensita e depende da composição da liga (MELING e ODEGAARD, 2001).

\subsubsection{Biocompatibilidade e citotoxicidade das ligas Níquel-Titânio}

Para melhor entender as reações biológicas frente ao uso dos diversos materiais, deve-se conhecer os conceitos de biocompatibilidade, toxicidade, alergia e hipersensibilidade, a fim de compreender as condições de alguns pacientes que apresentam alterações no sistema imune.

A biocompatibilidade ocorre quando os tecidos entram em contato com um determinado material e não manifestam qualquer tipo de experiência tóxica, irritante, inflamatória, alérgica ou de fundo mutagênico ou carcinogênico. A ocorrência de qualquer reação adversa é chamada de toxicidade. Para a biocompatibilidade de um determinado material é necessária uma resposta adequada do hospedeiro, o que, em Odontologia, significa a não-ocorrência de reações adversas, ou a ocorrência de reações adversas toleráveis, do organismo frente a esse material (MENEZES; FREITAS; GONÇALVES, 2009).

A citotoxicidade, ou avaliação da toxicidade em cultura de células, é um fenômeno in vivo complexo, o qual pode manifestar um amplo espectro de efeitos, desde uma simples morte celular até aberrações metabólicas, nas quais não ocorre morte celular, mas apenas alterações funcionais. A genotoxicidade avalia o dano ao DNA e é, geralmente, utilizada para auxiliar na investigação de potenciais efeitos, benéficos ou danosos, de diferentes agentes (MENEZES; FREITAS; GONÇALVES, 2009). 
As reações de hipersensibilidade são desordens que têm origem numa resposta imune que se torna exagerada ou inapropriada, ocasionando lesões sobre células ou tecidos normais do organismo, enquanto alergia significa uma hipersensibilidade específica adquirida do sistema imune, tanto de uma fonte exógena quanto endógena (MENEZES; FREITAS; GONÇALVES, 2009).

Há uma preocupação em se definir a resistência a corrosão das ligas de NiTi uma vez que as mesmas são utilizadas como biomaterial, que seria identificar se íons são liberados pelo processo corrosivo. A liberação do níquel, caso ocorra, além de sensibilizar alguns pacientes, produzindo reação alérgica, pode afetar a integridade mecânica do fio causando sua fratura e consequientemente, provocar danos ao paciente (BUCCI; CÂNDIDO; GOMES, 2003).

A resistência à corrosão das ligas de níquel-titânio é dada pela formação de um filme de passivação constituído de $\mathrm{TiO}_{2}$ (BUCCI; CÂNDIDO; GOMES, 2003), pois a superfície do níquel-titânio consiste em grande quantidade de óxido de titânio $\left(\mathrm{TiO}_{2}\right)$, menores quantidades de óxidos de níquel $\left(\mathrm{NiO}\right.$ e $\left.\mathrm{Ni}_{2} \mathrm{O}_{3}\right)$ e níquel metálico sendo a camada interna constituída de níquel-titânio. A espessura da camada de óxido varia entre 2-20 nm. A superfície de NiTi é na sua maioria composta por oxigênio, carbono e óxido de titânio com resquícios de níquel, o qual dissolve mais facilmente do que titânio porque seu óxido é menos estável (PÉRTILE, 2005).

Estudo realizado por Rondelli e Vicentini (1999) demonstrou comportamento localizado da corrosão de fios de NiTi em fluídos que simulam os fluídos do corpo humano, comparando-os com fios feitos do aço inoxidável e da liga base-cobalto. Os testes potenciodinâmicos realizados em saliva artificial a $40^{\circ} \mathrm{C}$ indicaram uma resistência ao pite para os fios do $\mathrm{NiTi}$, similar àquela do fio da liga de cobalto, porém o fio de aço inoxidável apresentou baixo potencial de resistência ao pite. Os testes potenciodinâmicos em $40^{\circ} \mathrm{C}$ em solução salina isotônica $(0.9 \% \mathrm{NaCl})$ para o $\mathrm{NiTi}$ e fios de aço inoxidáveis (em valores potenciais de pite na escala $200-400 \mathrm{mV}$ e $350 \mathrm{Mv}$ ), mostraram que estes materiais devem ser considerados potencialmente susceptíveis ao pite, apenas a 
liga cobalto-base foi considerada imune do pite. Os potenciais de corrosão localizados determinados pelo teste de ASTM F 746 (0-200 mV e $130 \mathrm{mV}$ para NiTi e o aço inoxidável, respectivamente) indicam que estes materiais possuem um risco mais elevado de corrosão localizada.

A resistência à corrosão da maioria dos metais, com exceção dos metais nobres, é dada pela presença de um filme óxido. A formação deste filme de óxido superficial é de grande importância para a resistência à corrosão da liga de NiTi, pois age como barreira contra a migração e dissolução de íons de níquel a partir da superfície do metal (SHABALOVSKAYA, 2002).

Com o número crescente de tratamentos ortodônticos utilizando dispositivos que contenham níquel e a predominância crescente de alergia a esse elemento desenvolvida pela população levaram ao desenvolvimento de pesquisas buscando avaliar a resistência a corrosão desses materiais. Os fios de NiTi são produzidos por vários processos de fabricação o que pode acarretar em comportamentos distintos quanto a resistência à corrosão no meio bucal.

Figueira et al (2009) realizaram estudo sobre a corrosão de ligas de NiTi em solução de Hank's a $37^{\circ} \mathrm{C}$ utilizando método eletroquímico e comparando esta liga com o titânio comercialmente puro, níquel comercialmente puro, com a liga Ti-6Al-4V e aço inoxidável 316L, materiais comumente utilizados em implantes. Observaram que a corrosão foi menor na superfície do titânio que na superfície do níquel, de acordo com a curva de polarização, devido à formação de uma camada passiva de óxido. No entanto, fluoretos são inimigos dos metais reativos, como o titânio e suas ligas, especialmente em meio ácido, causando corrosão da camada passiva e perda das propriedades mecânicas (AL-MAYOUF, 2004). Esse fator é preocupante, pois os enxaguatórios contendo flúor são amplamente utilizados na Odontologia para manutenção da boa higiene oral e auxilia na diminuição do índice de cárie. O flúor promove a formação de compostos fluoretados que aderem aos dentes e estimulam a remineralização, enquanto protegem os dentes contra os ataques de ácidos (SHIFF; GROSGOGEAT; DALARD, 2004). 
Os efeitos dos fluoretos na resistência à corrosão do titânio e suas ligas foram avaliados por Kaneko et al. em 2004. Os autores estudaram a degradação de quatro fios ortodônticos (NiTi, beta-titânio, aço inoxidável e níquel-cromocobalto) após a imersão desses materiais em solução acidulada do fluoreto do fosfato de $2.0 \%$ em temperatura de $37^{\circ} \mathrm{C}$ por 60 minutos. Observaram que as propriedades mecânicas do níquel-titânio e titânio-beta foram alteradas sensivelmente, sendo que o modo de fratura mudou de dúctil para frágil. Por outro lado, a resistência à tração dos arcos de aço inoxidável e de níquel-cromocobalto foi apenas levemente afetada pela imersão. Os autores sugerem que a degradação de arcos ortodônticos de ligas de titânio ocorra por causa da absorção do hidrogênio mesmo depois de curto período de imersão em soluções do fluoreto.

Schiff, Grosgogeat e Dalard (2004) classificaram diferentes ligas utilizadas de acordo com a resistência à corrosão. Quatro materiais foram analisados (TMA, TiNb, NiTi e NiTiCu) e testados em três colutórios contendo flúor (Elmex, Meridol e Acorea) e saliva artificial Fusayama-Meyer. Por meio de estudo eletroquímico as ligas foram divididas em dois grupos: um grupo baseado em ligas de NiTi sujeitas à forte corrosão na presença de monofluorfosfato encontrado em solução de Acorea e outro grupo baseado em TiNb que foi mais resistente à corrosão e TMA que corroeu fortemente na presença de fluoreto de estanho encontrado no Meridol. Pelos resultados, pode-se recomendar o colutório de acordo com a fase de tratamento e a liga que está sendo aplicada. Assim, é propício indicar Elmex para pacientes que usam TMA e NiTi e Acorea ou Meridol para pacientes que usam arco TiNb.

\subsection{TRATAMENTO DE SUPERFÍCIE}

Os materiais metálicos empregados em aplicações biomédicas, como aço inoxidável, ligas cobalto-cromo e ligas níquel-titânio, apresentam como principal desvantagem, após longo uso, a liberação de íons metálicos e conseqüentemente, um aumento do efeito citotóxico. Por exemplo, o aço inoxidável quando 
empregado na fabricação de vasos coronários pode corroer e liberar íons níquel e cromo. Dessa forma, a modificação de superfície torna-se uma ferramenta importante para melhorar a biocompatibilidade desses materiais (ROY e LEE, 2007).

Nos últimos anos, o carbono tipo diamante (DLC - Diamond Like Carbon) tem emergido com um material potencial para essas aplicações devido à sua elevada dureza, baixo coeficiente de fricção, à elevada resistência ao desgaste e à corrosão. Os filmes de DLC são materiais amorfos metaestáveis, compostos principalmente por átomos de carbono ligados por hibridações $\mathrm{sp}^{2} \mathrm{e} \mathrm{sp}^{3} \mathrm{em}$ uma cadeia desordenada. É importante observar que o DLC não é um material específico, mas um grupo de materiais com uma ampla faixa de estruturas com ligações atômicas diferentes. Os carbonos hidrogenados podem ser classificados em quatro tipos de acordo com o teor de hidrogênio (CASIRAGHI, FERRARI e ROBERTSON, 2005):

(a) Filmes a-C:H com elevado conteúdo de $\mathrm{H}$ (40-60\%at); estes filmes podem ter até $70 \%$ de ligações $\mathrm{sp}^{3}$. Entretanto, a maioria das ligações $\mathrm{sp}^{3}$ termina em hidrogênio, tornando-os materiais dúcteis e com baixa densidade;

(b) Filmes a-C:H com conteúdo intermediário de $\mathrm{H}$ (20-40\%at), possuem menor quantidade de ligações $\mathrm{sp}^{3}$, o que lhes confere melhores propriedades mecânicas.

(c) Filmes de carbono amorfo tetraédrico hidrogenado (ta-C:H) possuem de 25-30\% at de hidrogênio;

(d) a-C:H com baixo conteúdo de hidrogênio (menor do que $20 \%$ at). Eles têm elevado conteúdo de $\mathrm{sp}^{3}$. Nós chamamos estes filmes de grafíticos $\mathrm{a}-\mathrm{C}: \mathrm{H}$.

Na figura 9 temos a representação do diagrama ternário de fases para o DLC. Nos vértices do triângulo encontram-se os pontos para 100\% de ligações $\mathrm{sp}^{2}, \mathrm{sp}^{3}$ e para $\mathrm{H}_{2}$. Outras regiões do diagrama definem grupos específicos de carbono, tais como os carbonos amorfos formados, os tetraédricos (ta-C), os grafíticos (a-C), assim como suas fases hidrogenadas, representadas pelo ta-C:H 
e a-C:H. Podem ser observadas também as regiões onde o carbono vítreo e polímeros HC são formados e também a região na qual não há formação de filme .

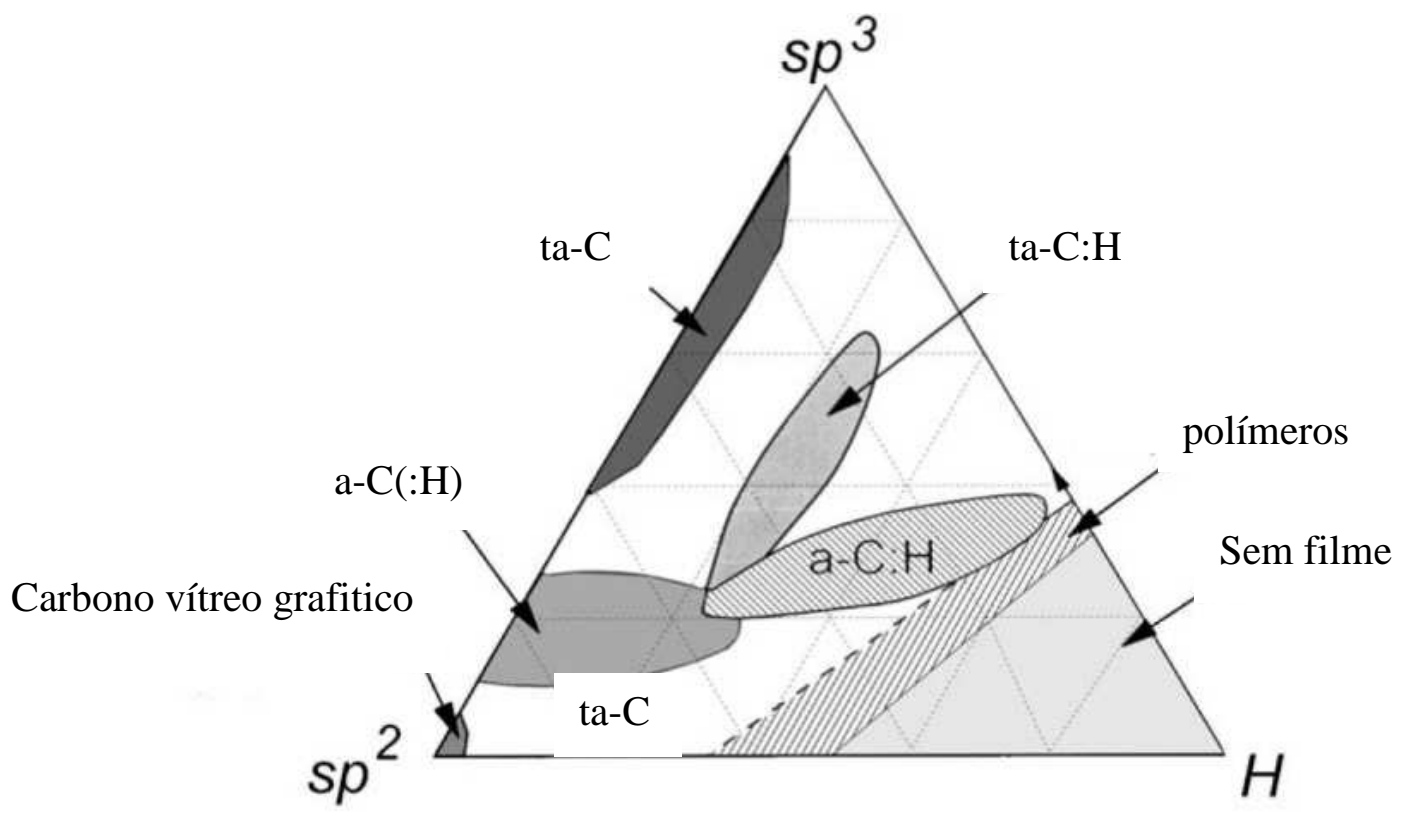

Figura 9 - Diagrama ternário de fases do DLC (CASIRAGHI, FERRARI e ROBERTSON, 2005)

No Quadro 2 temos a comparação das principais propriedades dos compostos de carbonos amorfos com diamante, grafite, $\mathrm{C}_{60}$ e polietileno (ROBERTSON, 2002). 
Quadro 2 - Comparação das propriedades de carbonos amorfos com diamante, grafite, $\mathrm{C}_{60}$ e polietileno (ROBERTSON, 2002)

\begin{tabular}{|c|c|c|c|c|c|}
\hline & $\mathrm{sp}^{3}$ & $\mathbf{H}(\%)$ & densidade $\left(\mathrm{g} / \mathrm{cm}^{3}\right)$ & GAP $(e V)$ & Dureza (GPa) \\
\hline Diamante & 100 & 0 & 3,525 & 55 & 100 \\
\hline Grafite & 0 & 0 & 2,267 & 0 & \\
\hline $\mathrm{C}_{60}$ & 0 & 0 & & 1,6 & \\
\hline Carbono vítreo & 0 & 0 & $1,3-1,55$ & 0,01 & 3 \\
\hline ta-C & $80-88$ & 0 & 3,1 & 2,5 & 80 \\
\hline a-C:H(durezaelevada) & 40 & $30-40$ & $1,6-2,2$ & $1,1-1,7$ & $10-20$ \\
\hline a-C:H(dureza baixa) & 60 & $40-50$ & $1,2-1,6$ & $1,7-4$ & $<10$ \\
\hline ta-C:H & 70 & 30 & 2,4 & $2,0-2,5$ & 50 \\
\hline Polietileno & 100 & 67 & 0,92 & 6 & 0,01 \\
\hline
\end{tabular}

\subsubsection{Técnicas de deposição}

Os filmes de DLC vêm sendo produzidos por uma grande variedade de métodos, incluindo deposição química a vapor, assistida por plasma DC e RF, sputtering, ou deposição por feixe de íons, a partir de uma variedade de fontes de carbono, seja como substrato, sólido ou fonte gasosa do material (NOGUEIRA, 2002).

Os filmes a-C: $\mathrm{H}$ podem ser depositados à partir de várias fontes de gases precursores, tais como: $\mathrm{CH}_{4}, \mathrm{C}_{2} \mathrm{H}_{2}, \mathrm{C}_{2} \mathrm{H}_{4}$ e $\mathrm{C}_{6} \mathrm{H}_{6}$. 
Jones et al (2000) estudaram a hemocompatibilidade dos revestimentos de DLC, TiN e TiC depositado em substratos de titânio para uso em válvulas cardíacas através da absorção de proteínas sanguíneas e a adesão plaquetária. A absorção de albumina e do fibrinogênio nas superfícies dos revestimentos foi avaliada. A formação de trombos foram observados nas superfícies de TiN e TiC, exceto nos revestimentos de DLC. Sendo assim, a boa hemocompatibilidade do DLC se dá pela hidrofobicidade e lisura superficial quando comparados a outras superfícies.

Yang et al (2004) estudaram a relação entre as propriedades físicas do revestimento de carbono amorfo hidrogenado (a-C:H) e sua compatibilidade com o sangue humano. Os filmes de (a-C:H) foram produzidos usando a implantação iônica por imersão a plasma (PIIID), com aquecimento a vácuo entre $200^{\circ}$ e $600^{\circ}$ C. Observou-se que o aquecimento a baixas temperaturas não causou regressão da biocompatibilidade sanguínea do filme de (a-C:H) sendo que a ação da aderência plaquetária na superfície dos filmes foram elevadas para temperaturas acima de $400{ }^{\circ} \mathrm{C}$. Relatam também que a mudança das propriedades físicas do filme (limitação tanto da banda gap como do fibrinogênio), aumenta a concentração e condutividade. Sendo assim, a compatibilidade dos filmes de (a$\mathrm{C}: \mathrm{H})$ foram afetados pela estrutura eletrônica e constatou-se que a melhora desta estrutura é importante para a inibição da ativação plaquetária.

Yang et al (2006) estudaram a estrutura e as propriedades das películas do carbono amorfo hidrogenado (a-C: H) para aplicações biomédicas. Também investigaram a relação entre as propriedades físicas destes filmes e sua compatibilidade no sangue. Os filmes foram fabricados usando a técnica de deposição por implantação iônica a plasma, seguido de recozimento a 200 e $600{ }^{\circ} \mathrm{C}$. Os filmes foram analisados por Espectroscopia Raman e microscopia de força atômica (AFM). A adesão, a ativação e a morfologia das plaquetas foram investigadas usando a microscopia eletrônica de varredura (SEM). A adesão plaquetária e a ativação da a-C: $\mathrm{H}$ foram afetadas pelo recozimento acima de $400^{\circ} \mathrm{C}$. Dessa forma, a compatibilidade sanguínea dos filmes foi afetada pela estrutura eletrônica. 
Sui e Cai (2006) estudaram as ligas de níquel-titânio revestidas com DLC empregando a implantação iônica. Os autores observaram que a deposição do filme DLC levou a uma melhor resistência a corrosão e hemocompatibilidade sanguínea, sem deterioração do efeito memória de forma e superelasticidade.

\subsubsection{CARACTERIZAÇÃO DOS FILMES DE DLC}

A espectroscopia Raman é uma técnica analítica não destrutiva empregada na caracterização de materiais carbonosos. É comumente realizada para avaliar comprimentos de onda na região do espectro azul-verde (488-514,5 nm), mas Espectroscopia Raman multi-comprimento de onda (MW Raman) é também empregada (FERRARI, 2005).

Os espectros Raman de todos os materiais carbonosos exibem seus picos característicos de $1^{\mathrm{a}}$ ordem na região entre 1000 e $1800 \mathrm{~cm}^{-1}$ para energia de excitação no visível e infravermelho. Para os materiais grafíticos, essa região é referente às bandas $\mathrm{D}\left(1200 \mathrm{a} 1400 \mathrm{~cm}^{-1}\right)$ e $\mathrm{G}\left(1500 \mathrm{a} 1600 \mathrm{~cm}^{-1}\right)$ atribuídas às ligações $\mathrm{sp}^{2}$. Para filmes de diamante, um pico bem definido pode ser visto em $1332 \mathrm{~cm}^{-1}$, referente às ligações do tipo $\mathrm{sp}^{3}$. Já, os espectros Raman de DLC consistem em bandas largas, típicas de materiais amorfos desordenados, apresentando ligações $\mathrm{C}-\mathrm{C}$ do tipo $\mathrm{sp}^{3}, \mathrm{sp}^{2}$ e $\mathrm{sp}^{1}$. As letras derivam de diamante(D) e grafite(G) e a deconvolução do espectro permite visualização das

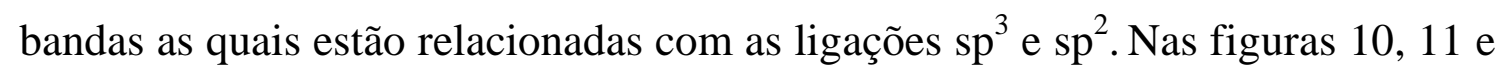
12 temos os espectros dos filmes tipo diamante, tipo grafite e DLC (LOBO, 2005). 


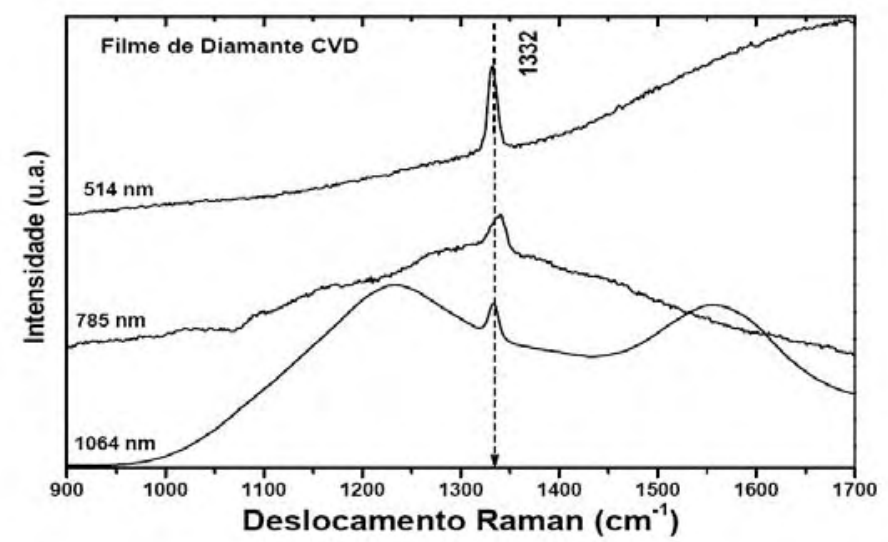

Figura 10 - Espectros Raman de filmes de diamante excitados com três diferentes comprimentos de onda (LOBO et al, 2005)

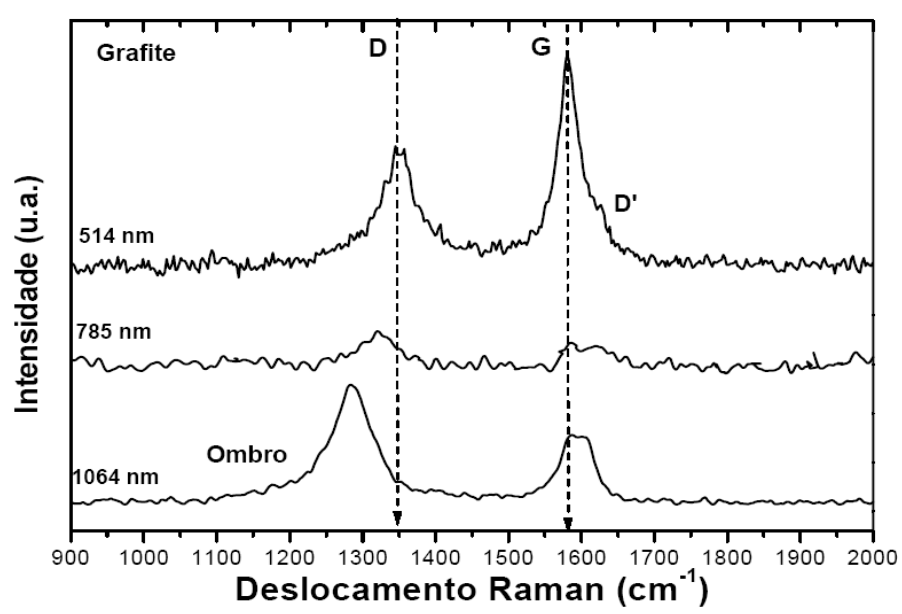

Figura 11 - Espectros Raman de filmes de grafite excitados com três diferentes comprimentos de onda (LOBO et al, 2005) 


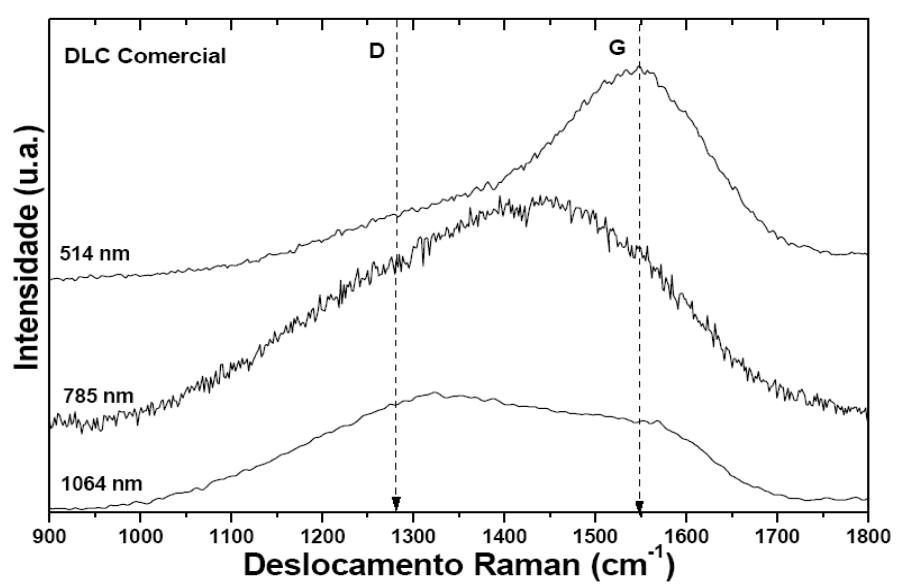

Figura 12- Espectros Raman de filmes de DLC excitados com três diferentes comprimentos de onda (LOBO et al, 2005)

A adsorção de produtos químicos pela superfície dos materiais é um dos fatores que podem afetar as aplicações destes materiais em vários ramos da indústria. $\mathrm{O}$ acúmulo de material na superfície pode provocar a degradação local do material, gerando pequenos defeitos como furos e corrosões localizadas. Existem diversas técnicas que podem ser empregadas no estudo da adsorção de produtos químicos pelos materiais. Uma das técnicas empregada é a de ângulo de contato, que é uma medida macroscópica em que é pipetada uma gota de uma dada solução sobre as amostras. Após a deposição da gota observa-se a forma da gota e a curvatura da mesma, conforme demonstrado na figura 13.

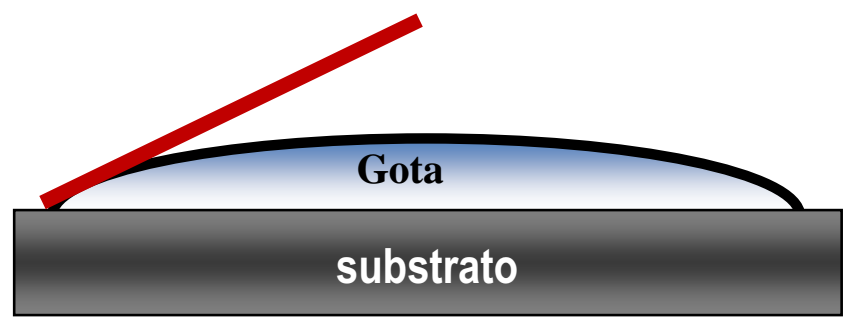

Figura 13 - Representação esquemática do ângulo de contato 
Pela medida do ângulo da curvatura pode-se relacionar ângulo de contato com a tensão superficial apresentada pelo material em relação à solução empregada. $\mathrm{O}$ aumento no ângulo de contato, que corresponde à menor tensão superficial apresentada, significa menor aderência da solução aos materiais empregados (NOGUEIRA, 2002).

Quando o ângulo de contato é menor que $90^{\circ}$, o material possui uma característica hidrofílica e quando é maior que $90^{\circ}$ apresenta característica hidrofóbica. Essa propriedade é chamada de molhabilidade do material, e está ligada com a energia de superficial do material.

O conceito de energia superficial pode ser explicado usando um líquido como exemplo, onde átomos e moléculas do líquido se movem livremente procurando ocupar uma posição de menor energia potencial, isto é, onde as forças (atrativas e repulsivas) estejam em equilíbrio. Entretanto, as partículas na superfície do material experimentam somente forças dirigidas para dentro do líquido, garantindo à superfície maior energia. A energia superficial é dada pela diferença entre as energias na superfície e no interior do material (BOYAN et al., 2003).

Dois métodos de cálculos são usados para determinação da energia de superfície, o método harmônico e o geométrico. Usando-se dois líquidos para a medida dos ângulos de contato; cujas componentes polar e dispersiva sejam conhecidas; pode-se determinar as componentes da energia de superfície do sólido.

Atualmente, estas medidas são relativamente fáceis de serem obtidas através de sistemas com microcâmera e computador. Estas fornecem os valores de energia de superfície, calculadas por ambos os métodos, imediatamente após as medidas dos ângulos de contato. 


\section{MATERIAIS E MÉTODOS}

Neste trabalho foram utilizados amostras e arcos de fios ortodônticos NiTi superelástico e termoativado, disponíveis no mercado. Na figura 14 verificamos a metodologia empregada para o desenvolvimento do presente estudo.

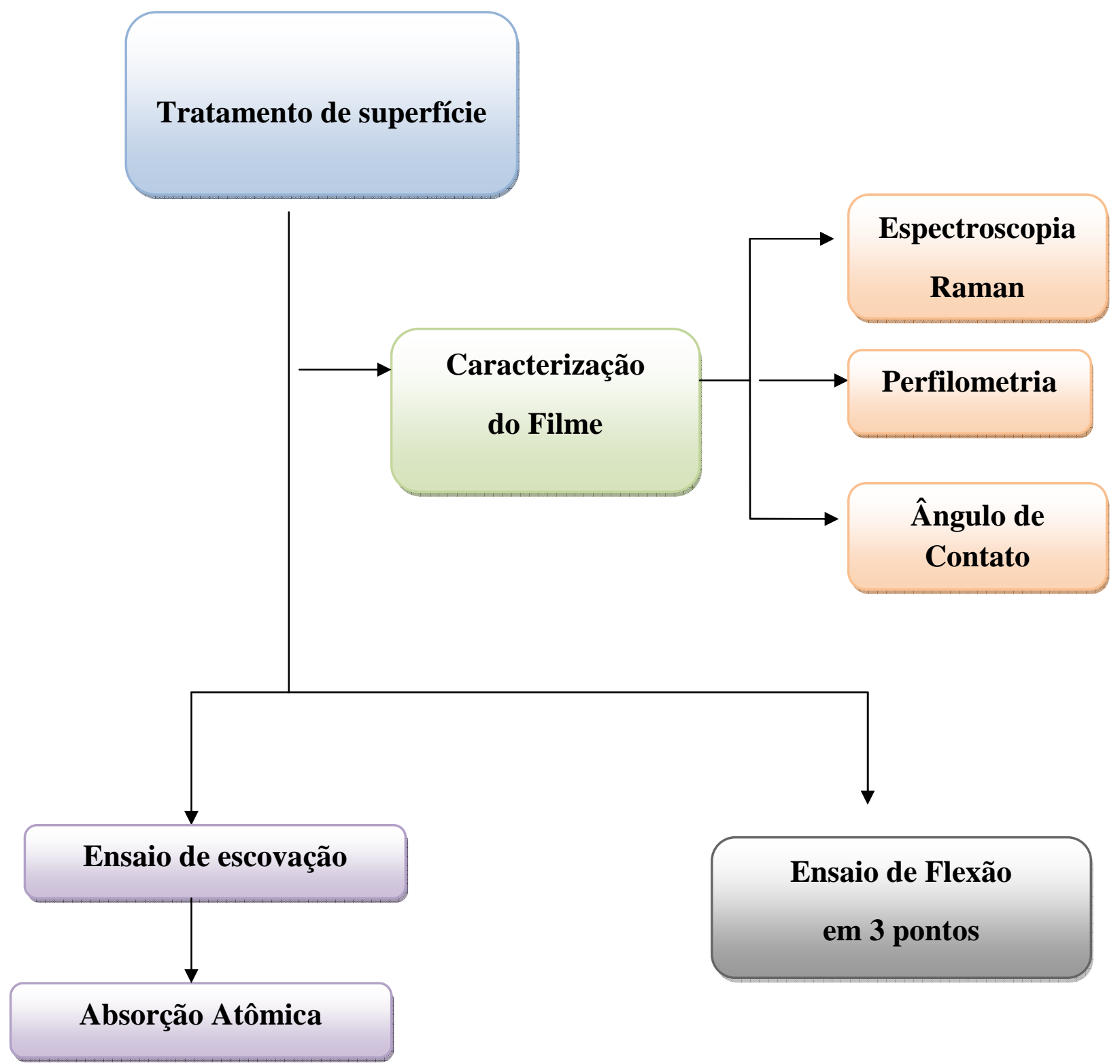

Figura 14 - Fluxograma demonstrativo da metodologia empregada. 


\subsection{TRATAMENTO DE SUPERFÍCIE}

\subsubsection{Processo de deposição dos filmes DLC}

A técnica escolhida para a deposição dos filmes de carbono amorfo hidrogenado foi a deposição química por plasma de rádio freqüência (RadioFrequency Plasma-Enhanced Chemical Vapor Deposition - RF PECVD), realizada no Laboratório de Plasma, Faculdade de Engenharia, Campus de Guaratinguetá (UNESP). O reator e todo equipamento utilizado para a deposição dos filmes é mostrado na figura 15.

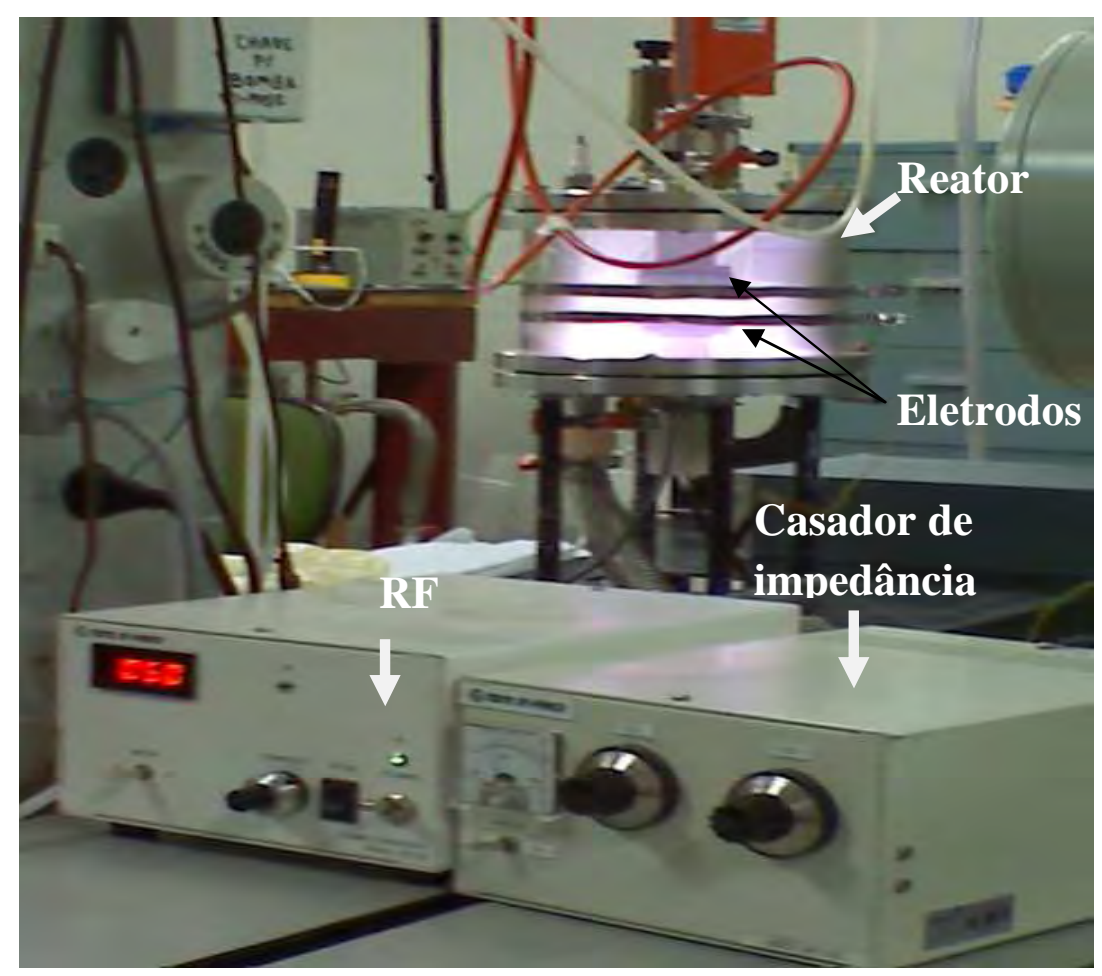

Figura 15 - Equipamentos utilizados para a deposição filmes DLC

Para a realização da deposição foi empregado um sistema constituído por um reator de vidro no formato cilíndrico medindo $180 \mathrm{~mm}$ de diâmetro por 140 $\mathrm{mm}$ de altura, com volume aproximado de 3 litros. O plasma é estabelecido entre dois eletrodos circulares, internos planos e paralelos, sendo um deles aterrado, medindo $100 \mathrm{~mm}$ de diâmetro. 
O processo de limpeza no interior da câmara foi efetuado por meio de uma bomba mecânica (M18, Edwards). Esse equipamento possui uma válvula solenóide, acoplada a sua saída, a qual é responsável pela admissão automática de ar atmosférico no seu desligamento. Este procedimento evita o refluxo do óleo da bomba para o interior da câmara de plasma, conectada à bomba por meio de uma válvula esférica e um tubo flexível de aço inoxidável. O controle da pressão no interior do reator de plasma foi realizado por meio de um sensor (Edwards) operando na faixa de pressão de $10^{5}$ a $10^{-2} \mathrm{~Pa}$ e a leitura do valor de pressão foi realizada por meio de uma unidade digital controladora de pressão.

Os plasmas foram excitados por meio de uma fonte de radio frequiência (modelo RF- 300 Tokyo HY-Power) operando na freqüência de 13,6 MHz com a potência de $50 \mathrm{~W}$, acoplada ao reator por meio de cabos coaxiais e um sistema casador de impedância (modelo MB-300Tokyo HY-Power). Um diagrama de blocos do sistema pode ser visualizado na figura 16 .

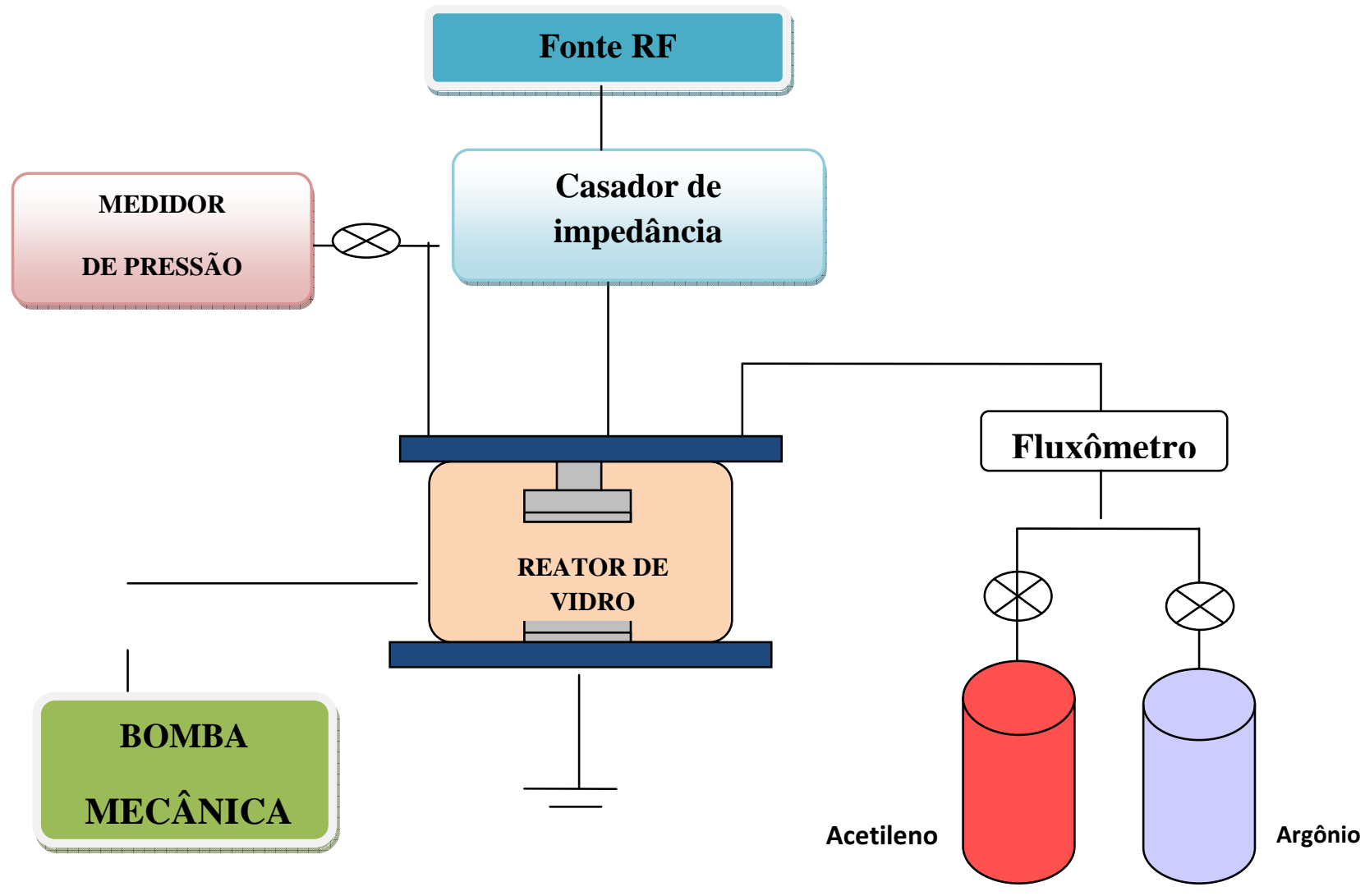

Figura 16 - Diagrama de blocos do sistema de deposição de filmes DLC 


\subsubsection{Limpeza dos substratos}

Nesse estudo foram empregados três tipos de substratos: lâminas de vidro e silício (para caracterização do filme depositado), os arcos ortodônticos (NiTi e termoativados para ensaio de escovação e absorção atômica) e as amostras destes fios para o ensaio de flexão).

As lâminas de vidro e o sílicio foram colocados em uma solução com detergente próprio para limpeza de amostras, deixados por 15 minutos em cuba ultrassônica e lavados em água corrente. Em seguida, foram imersos em água destilada, colocados em ultrassom por mais 15 minutos e lavados individualmente em água destilada. Posteriormente, foram mergulhados em álcool isopropílico, e acondicionados em ultrassom por 15 minutos. Concluído este processo de limpeza, foi realizada secagem em estufa a $160^{\circ} \mathrm{C}$ por 30 minutos.

As amostras e os arcos foram limpos de acordo com as seguintes etapas: primeiramente foi realizada lavagem manual com gaze e sabão (DET LIMP S 32) e enxaguados em água corrente com auxílio de uma peneira. Com o auxilio de Becker, foram colocados em cuba ultrassônica Thomton T 14, com sabão de laboratório por 20 minutos e lavagem em água corrente e água destilada. Depois foi realizada imersão em água destilada e manutenção em cuba ultrassônica por 20 minutos, seguida de lavagem com água destilada e imersão em álcool isopropílico com manutenção no ultrassom por 20 minutos. Em seguida, foi realizada imersão em acetona com manutenção no ultrassom por 20 minutos. Concluído este processo, foi realizada secagem em estufa a $160^{\circ} \mathrm{C}$ por 30 minutos.

\subsubsection{Condições de deposição}

As condições empregadas para a deposição do filme foram as preconizadas por Marins em seu estudo (MARINS, 2003). Os plasmas foram excitados a partir de radiofrequiência, operando na freqüência de 13,56 Hz, na 
faixa de pressão de $10 \mathrm{~Pa}$, com potência de $50 \mathrm{~W}$. Misturas de acetileno e argônio foram empregadas na proporção de $70 \%$ de argônio e $30 \%$ de acetileno, com o tempo de deposição de 5 minutos.

Para limpeza do reator de outros gases ou elementos químicos foi realizado plasma de argônio com pressão de $2 \times 10^{-1}$ Torr, potência de $50 \mathrm{~W}$ e tempo de 20 minutos. Após a limpeza do reator anotou-se a pressão base de trabalho $\left(\mathrm{P}_{\mathrm{b}}\right)$ marcada no medidor digital, pois é através desta $\mathrm{P}_{\mathrm{b}}$ que se calcula $\mathrm{a}$ quantidade de argônio e de acetileno, ou seja, calcula-se a pressão de cada um deles através da pressão base para depositar $70 \%$ de argônio e 30\% de acetileno.

Para a obtenção de filme de DLC próximo da faixa de $10 \mathrm{~Pa}=7,5 \times 10^{-2}$ Torr empregou-se os seguintes parâmetros:

Pressão argônio: $2,3 \times 10^{-2}$ Torr,

Pressão acetileno: $5,3 \times 10^{-2}$ Torr

Sendo assim, temos:

Acetileno $30 \%=\mathrm{P}_{\mathrm{b}}+\mathrm{P}_{\mathrm{C} 2 \mathrm{H} 2}$

Argônio $70 \%=\mathrm{P}_{\mathrm{b}}+\mathrm{P}_{\mathrm{C} 2 \mathrm{H} 2}+\mathrm{Par}$

Após a deposição na base da amostra (lado 1), "quebrou-se" o vácuo e abriu-se o reator para realização da deposição do filme do lado oposto (lado 2), repetindo todo o processo desde a limpeza com plasma de argônio .

Para facilitar o entendimento de todo o processo de deposição, as amostras foram divididas em quatro grupos, conforme Tabela 1:

Grupo I: 10 corpos de prova de fio ortodôntico de NiTi retangular de $0,0215 "$ x 0,025", marca comercial, lote 2878023, para o ensaio de flexão em três pontos;

Grupo II: 10 corpos de prova de fios ortodônticos de NiTi Termoativado retangular de $0,0215 "$ x $0,025 "$, marca comercial, lote 2887001 , para o ensaio de 
flexão em três pontos;

Grupo III: 05 arcos ortodônticos NiTi retangular de 0,0215” x 0,025”, marca comercial, lote 2878023, para o ensaio de escovação, e

Grupo IV: 05 arcos ortodônticos de NiTi Termoativado retangular de 0,0215" x 0,025", marca comercial, lote 2887001, para o ensaio de escovação.

Tabela 1- Grupos e condições de deposição

\begin{tabular}{|c|c|c|c|c|}
\hline Grupo & Deposição & $\begin{array}{l}\text { Pressão base } \\
\text { de trabalho }\end{array}$ & $\begin{array}{c}\text { Pressão } \\
\text { acetileno } \\
30 \%\end{array}$ & $\begin{array}{c}\text { Pressão } \\
\text { argônio } \\
70 \%\end{array}$ \\
\hline \multirow{3}{*}{ I } & Lado 1 & $1,7 \times 10^{-2}$ Torr & $4,0 \times 10^{-2}$ Torr & $9,3 \times 10^{-2}$ Torr \\
\hline & Lado 2 & $1,2 \times 10^{-2}$ Torr & $3,5 \times 10^{-2}$ Torr & $8,8 \times 10^{-2}$ Torr \\
\hline & Lado 1 & $2,0 \times 10^{-2}$ Torr & $4,3 \times 10^{-2}$ Torr & $9,6 \times 10^{-2}$ Torr \\
\hline \multirow[t]{2}{*}{ II } & Lado 2 & $1,2 \times 10^{-2}$ Torr & $3,5 \times 10^{-2}$ Torr & $8,8 \times 10^{-2}$ Torr \\
\hline & Lado 1 & $1,1 \times 10^{-2}$ Torr & $3,35 \times 10^{-2}$ Torr & $8,6 \times 10^{-2}$ Torr \\
\hline \multirow[t]{2}{*}{ III } & Lado 2 & $1,0 \times 10^{-2}$ Torr & $3,25 \times 10^{-2}$ Torr & $8,5 \times 10^{-2}$ Torr \\
\hline & Lado 1 & $1,8 \times 10^{-2}$ Torr & $4,1 \times 10^{-2}$ Torr & $9,4 \times 10^{-2}$ Torr \\
\hline IV & Lado 2 & $1,3 \times 10^{-2}$ Torr & $3,6 \times 10^{-2}$ Torr & $8,9 \times 10^{-2}$ Torr \\
\hline
\end{tabular}

O tempo aproximado de deposição foi de 300 segundos, sendo que a polarização ocorreu pelo eletrodo inferior a fim de se proporcionar o crescimento de filmes mais duros, aderentes e com mais carbono (Figura 17). 


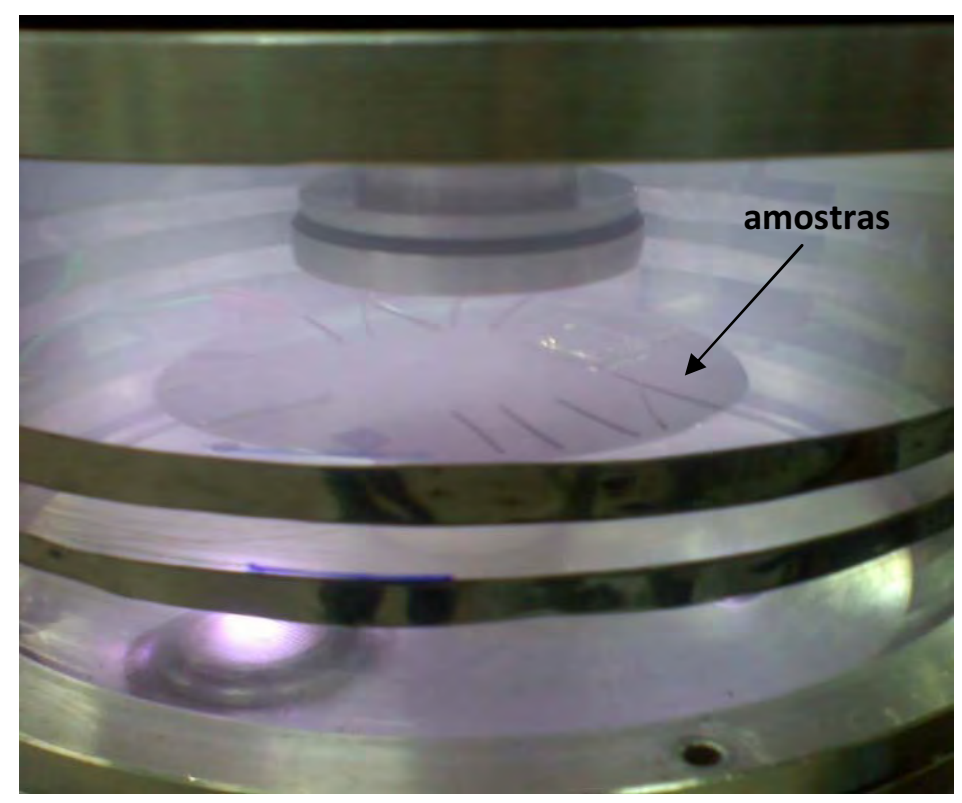

Figura 17 - Deposição de filme DLC nas amostras de NiTi

\subsection{CARACTERIZAÇÃO DOS FILMES}

\subsubsection{Perfilometria}

A espessura do filme de a-C:H foi medida no Laboratório de Sensores e Materiais - LAS - do Instituto de Pesquisa Espacial (INPE) em São José dos Campos, por meio de um Perfilômetro TENCOR ALPHA STEP (AS) 500 como mostra a figura 18.

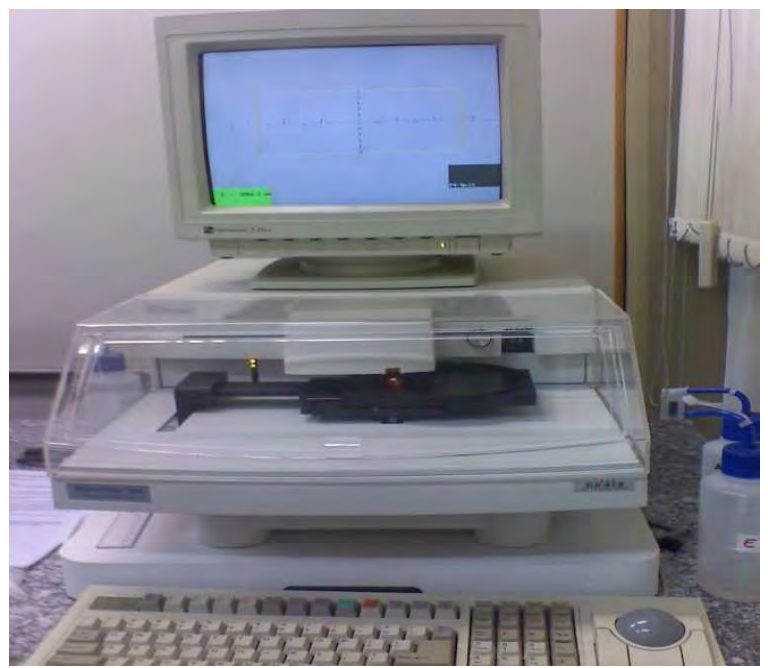

Figura 18 - Perfilômetro Tencor Alpha Step 500 
Os filmes foram depositados sobre substratos de vidro, onde parte da superfície do substrato é coberta por uma máscara de vidro de modo a apresentar um degrau entre a superfície do filme e a do substrato, como mostra a figura 19. Este degrau formado e sua medida (altura "h") corresponde à espessura do filme a qual é medida pela perfilometria.

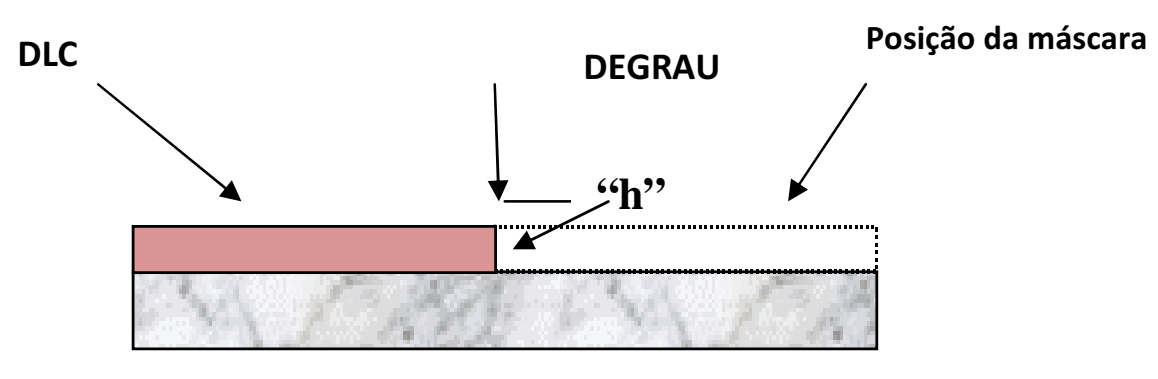

Figura 19 - Esquema ilustrativo do degrau para medida da espessura do filme de DLC

\subsubsection{Espectroscopia Raman}

A Espectroscopia Raman é uma técnica analítica que avalia a estrutura molecular de filmes carbonosos, verificando se este filme é do tipo polimérico ou DLC.

Os filmes de a-C:H foram caracterizados pela técnica de Espectroscopia Raman, realizado no Laboratório de Sensores e Materiais (LAS) do Instituto de Pesquisa Espacial (INPE) em São José dos Campos através do Espectrômetro Renishaw - Raman Imaging Microscope, por um Laser de Argônio excitados a $514 \mathrm{~nm}$ e a faixa de comprimento de onda analisado foi de 900 a $2000 \mathrm{~cm}^{-1}$.

O espectro Raman foi obtido através da incidência da luz monocromática do laser de argônio (514 nm) sobre a amostra do filme de a-C:H. A luz espalhada foi dispersa por uma rede de difração no espectrômetro e suas componentes foram recolhidas em um detector que converte a intensidade da luz 
em sinais elétricos que foram interpretados em um computador na forma de um espectro Raman. Os espectros obtidos eram deconvoluídos em duas curvas gaussianas, denominadas banda $\mathrm{G}$ (associado a hibridização $\mathrm{sp}^{2}$ ) e banda $\mathrm{D}$ (atribuído a hibridização $\mathrm{sp}^{3}$ ), segundo o procedimento proposto por Robertson (2002).

\subsubsection{Medida do ângulo de contato e energia de superficie}

Os ângulos de contato $(\theta)$ e energia de superfície foram obtidos através de um Goniômetro automatizado (Ramé-Hard-modelo 100-00), do Laboratório de Plasma da Faculdade de Engenharia de Guaratinguetá (FEG/UNESP). Este equipamento que é mostrado na figura 20 e é composto por uma câmera CCD, que captura a imagem da gota depositada sobre o filme. Um programa de tratamento de imagens determina o perfil desta gota, calculando o ângulo de contato.

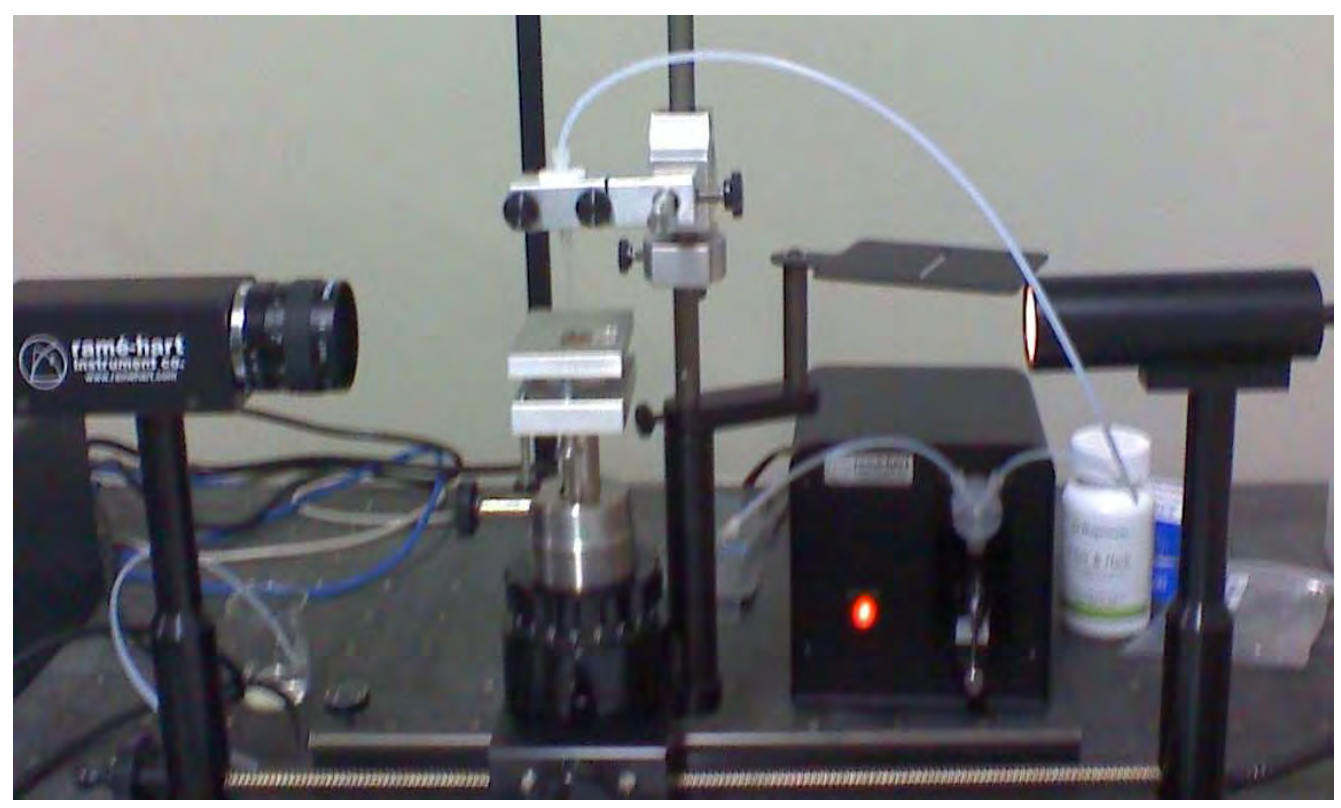

Figura 20 - Goniômetro automatizado (Ramé-Hard-modelo 100-00)

Nestas análises, utilizou-se o vidro como substratos dos filmes, a água deionizada como líquido polar e o diodometano como líquido apolar ou dispersivo. Para realização de análise estatística, três gotas foram depositadas 
sobre diversas superfícies das amostras e medidas 10 vezes. Estas análises foram realizadas 24 horas após as deposições como mostrado na figura 21.

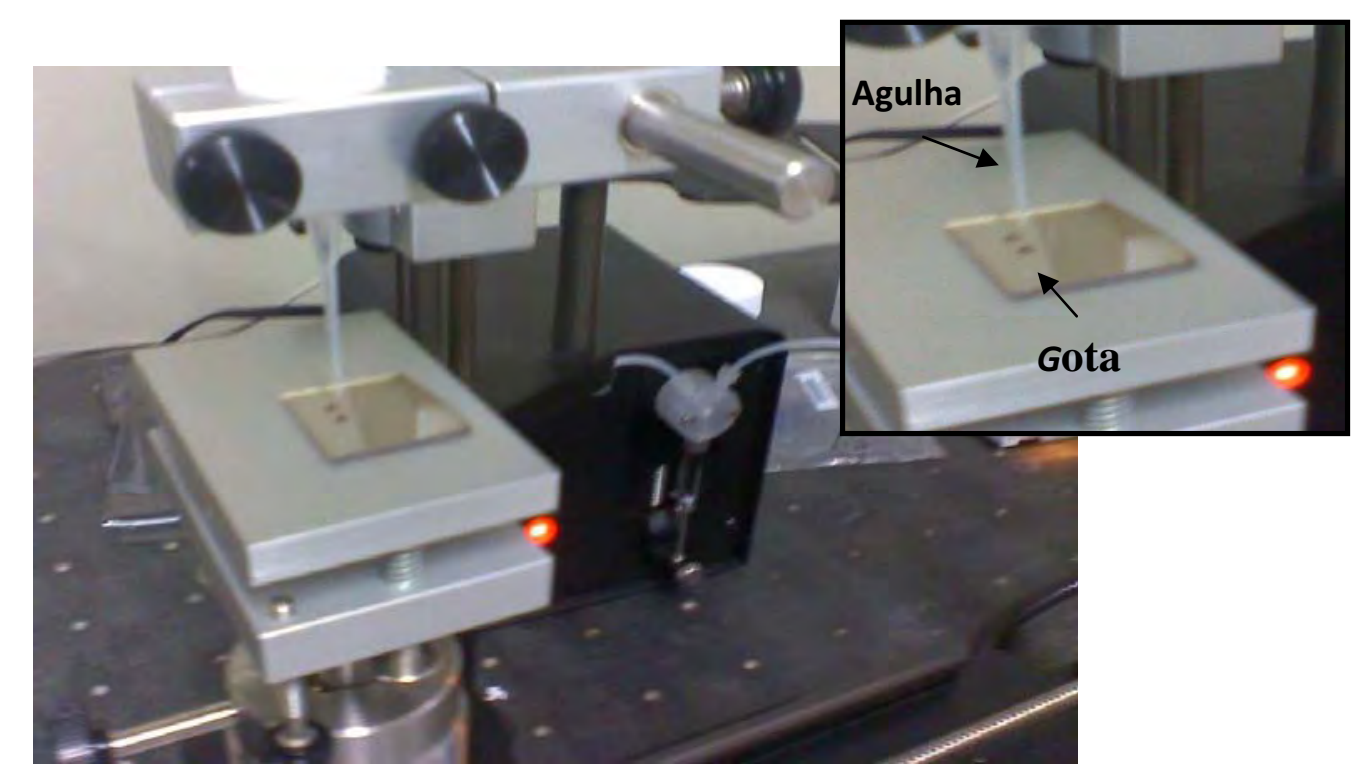

Figura 21 - Deposição da gota para cálculo do ângulo de contato

Através da medida do ângulo de contato temos a propriedade de molhabilidade do material, onde se este ângulo for menor que $90^{\circ}$ o material apresenta propriedade hidrofílica; e se for maior que $90^{\circ}$, o material tem uma característica hidrofóbica.

A energia de superfície é dada pelo trabalho de trazer uma partícula de dentro do líquido para fora, por unidade de superfície, num volume e temperatura constantes. A energia livre total numa superfície é a soma de contribuições de diferentes forças intermoleculares.

Dois métodos de cálculo são usados para determinação da energia de superfície considerando as componentes, polar e dispersiva (não polar): o método harmônico e o geométrico.

Atualmente, estas medidas são fáceis de serem obtidas através de sistemas com microcâmera e computador. Estas fornecem os valores de energia de superfície, calculadas por ambos os métodos, imediatamente após as medidas dos ângulos de contato como demonstrado na figura 22 . 

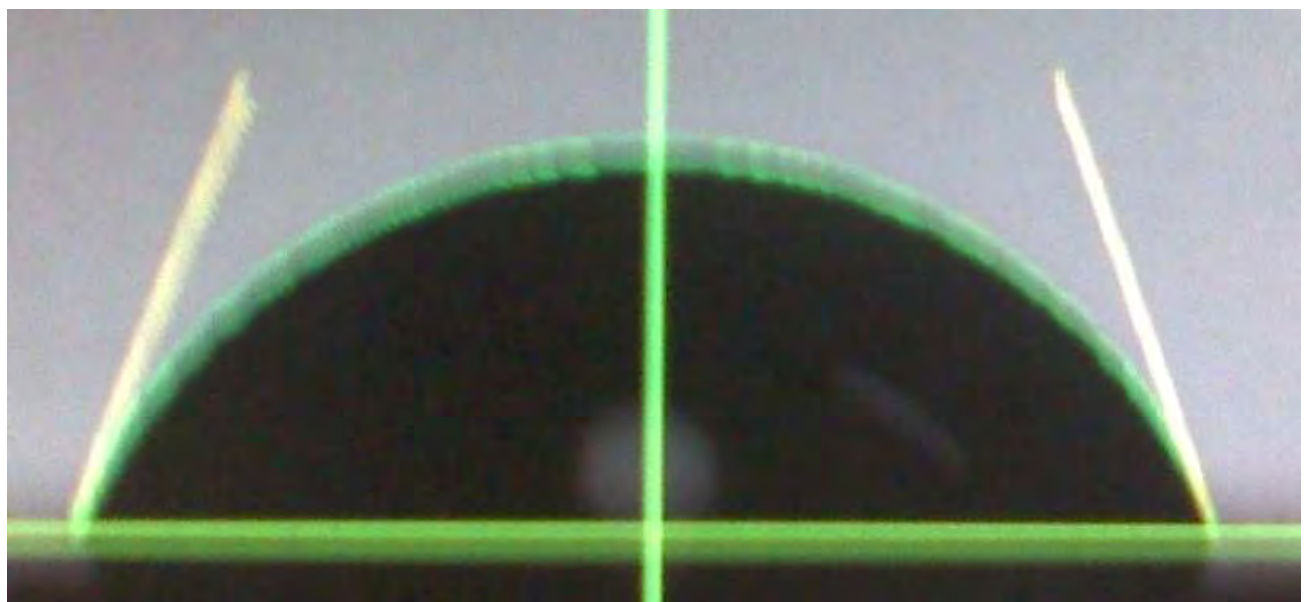

Figura 22 - Imagem da gota obtida pelo programa de computador para medida do ângulo de contato $(\theta)$

\subsection{ENSAIO DE ESCOVAÇÃO}

O ensaio de escovação foi realizado na Faculdade de Engenharia de Guaratinguetá (FEG/UNESP), para avaliação de liberação de íons. Foram confeccionados modelos em resina acrílica Dencor, realizada a colagem de braquetes poliméricos e a fixação dos arcos ortodônticos por meio de ligaduras elásticas utilizando instrumento sputnik, conforme figura 23.

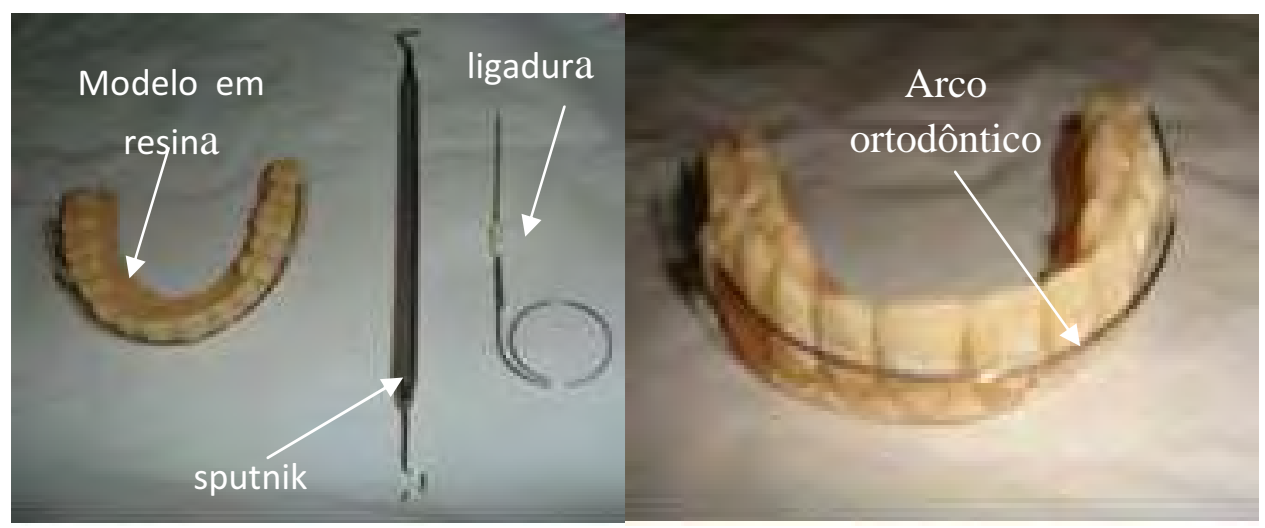

(a)

(b)

Figura 23 - (a) Modelo em resina e instrumental utilizado para fixação arco/braquete; (b) detalhe do modelo com arco 
Os arcos utilizados foram os de secção retangular com dimensão $0,025 " \mathrm{X}$ $0,021 "$.

Os modelos foram divididos em dois grupos:

> Grupo Experimental G1 (sem DLC + imersão em soro fisiológico + escovação + colutório) composto por 05 arcos de NiTi e $05 \operatorname{arcos~de~NiTi~}$ termoativado.

$>$ Grupo Experimental G2: (com DLC +imersão em soro fisiológico+ escovação + colutório) composto por 05 arcos de NiTi e 05 arcos de NiTi termoativado.

O Grupo Controle, onde os modelos ficaram imersos em soro fisiológico sem escovação, foi composto por 05 arcos de NiTi e 05 arcos de NiTi termoativado.

Estes modelos foram acondicionados em recipientes individuais e fechados, contendo $120 \mathrm{ml}$ de solução de soro fisiológico (cloreto de sódio a 0,9\%) conforme figura 24.

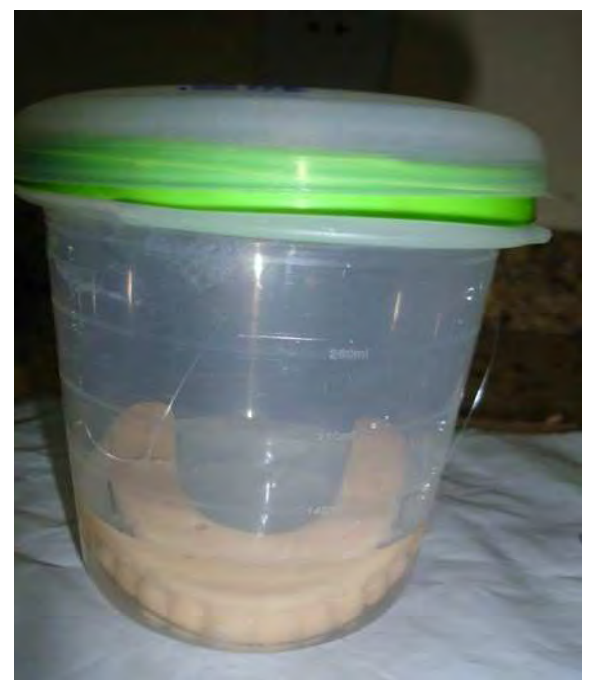

Figura 24 - Modelo acondicionado em recipiente com soro fisiológico

Os modelos foram colocados em um aquário de vidro contendo água a aproximadamente $34^{\circ}$ a $37^{\circ} \mathrm{C}$ simulando a cavidade oral como mostra a figura 25 . 


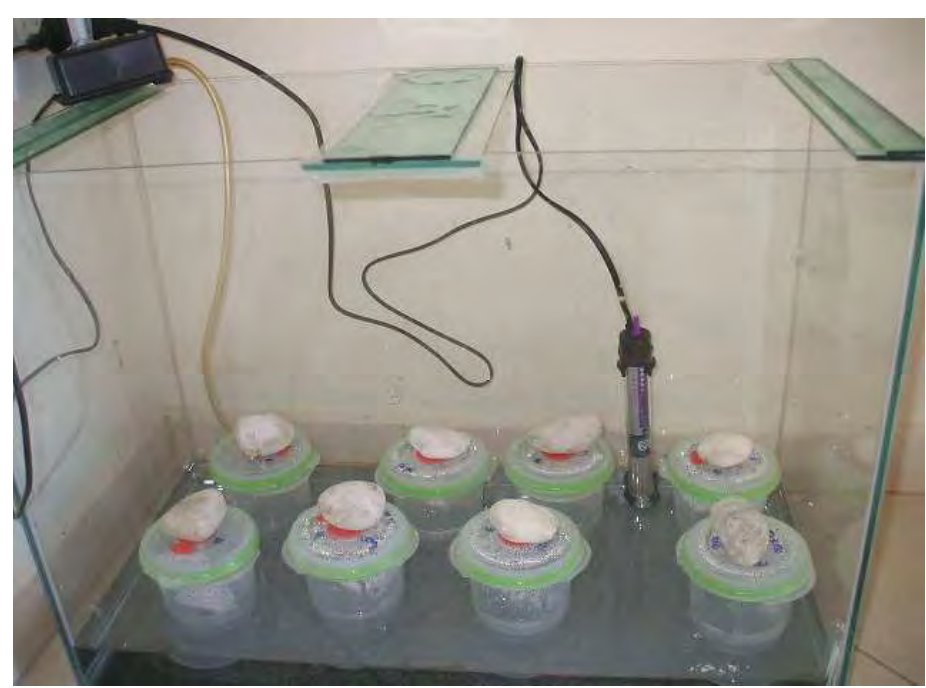

Figura 25 - Aquário com recipientes simulando meio bucal

Foi realizada a escovação manual dos arcos ortodônticos utilizando escova Oral B 30 (macia) e uma pequena quantidade de creme dental Colgate Total 12 por um período de 15 minutos para cada arco. Após a escovação, os modelos eram lavados em água destilada e imersos em colutório Cepacol por 05 minutos. Posteriormente eram enxaguados com água destilada e novamente colocados em seus respectivos recipientes contendo soro fisiológico.

Após 30 dias, as amostras foram retiradas dos potes e o líquido encaminhado para realização de Espectroscopia de Absorção Atômica.

\subsubsection{Espectrômetro de absorção atômica}

Para análise de absorção atômica utilizou-se o Espectrômetro de Absorção Atômica com atomização por Chama (Varian AA240Z) do Laboratório de Análises Químicas, do Departamento de Materiais e Tecnologia, da Faculdade de Engenharia Mecânica, do Campus de Guaratinguetá, UNESP, para avaliação da quantidade de íons metálicos liberados dos arcos, com e sem filme de DLC. 


\subsection{ENSAIO DE FLEXÃO EM TRÊS PONTOS}

O ensaio de flexão em três pontos foi realizado buscando-se avaliar a influência do tratamento de superfície nas propriedades mecânicas dos fios ortodônticos. Para isso, foram retiradas amostras da parte reta de secção transversal dos fios ortodônticos retangulares $(0,0215 "$ x 0,025 ") de NiTi ( lote 2878023 ) e NiTi termoativados ( lote 2887001), com comprimento de $20 \mathrm{~mm}$.

Foram divididos em dois grupos, sendo:

Grupo controle sem filme composto por 10 amostras de fios de NiTi e 10 amostras de NiTi termoativados.

$>$ Grupo experimental com filme composto por 10 amostras de fios de NiTi e 10 amostras de NiTi termoativados.

Esses testes foram realizados em uma máquina de ensaios mecânicos (EMIC) Modelo DL 3000, com célula de carga de $20 \mathrm{~N}$ pertencente ao Departamento de Materiais da Escola de Engenharia de Lorena- USP. Foram realizadas adaptações necessárias que podem ser observadas na figura 26. O sistema construído consiste em um dispositivo de pequeno porte que utiliza cargas menores que $20 \mathrm{~N}$, sendo possível o controle na velocidade de aplicação de carga, tanto no carregamento quanto no descarregamento.

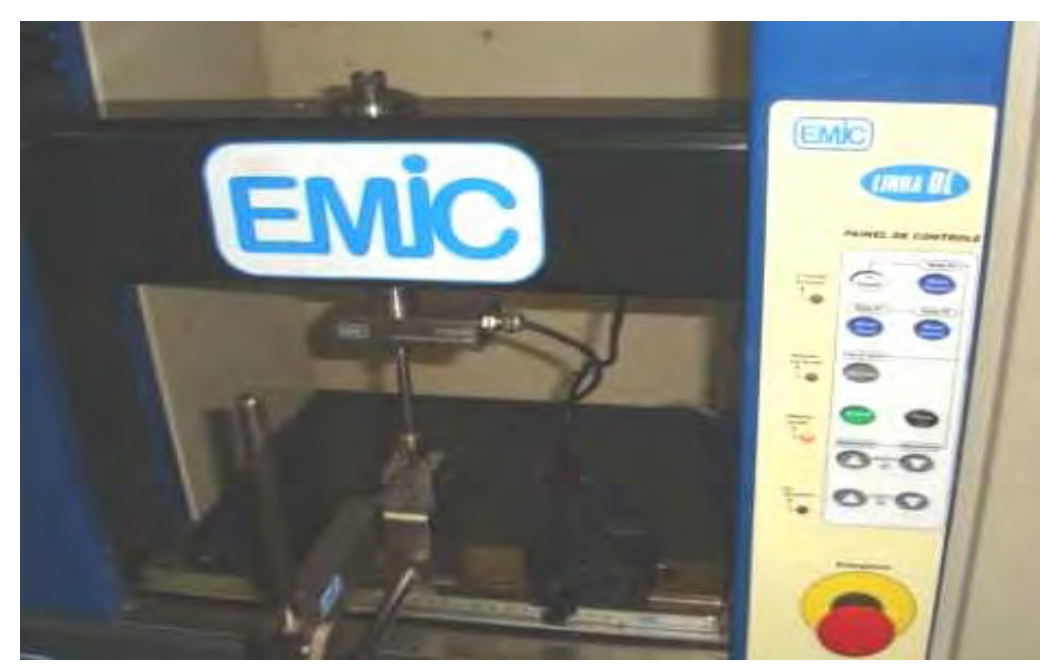

Figura 26- Equipamento EMIC, Modelo EE 050, com célula de carga de 20N utilizado para o ensaio de flexão três pontos 


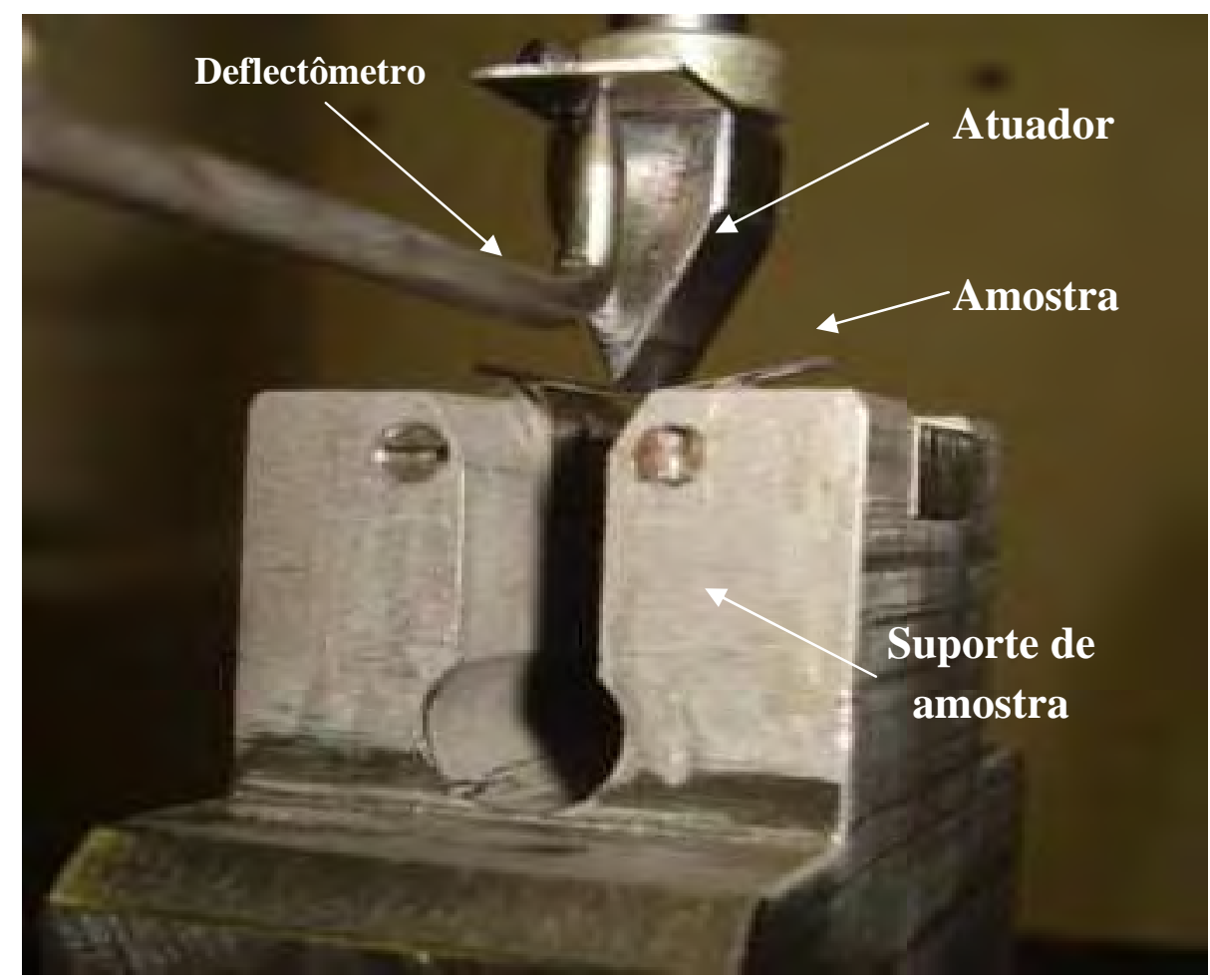

Figura 27 - Detalhamento do sistema para teste de flexão em três pontos

O suporte de amostra foi fabricado em aço inoxidável e a distância entre os apoios do fio nesse suporte é de $13 \mathrm{~mm}$. As medidas de deflexões foram obtidas utilizando-se um deflectômetro eletrônico da EMIC, modelo EE 050, com objetivo de medir a deflexão máxima de até $3,1 \mathrm{~mm}$, conforme pode ser observado na figura 27 e 28 . O atuador consiste de uma haste com uma ponteira em cunha feita de uma liga de titânio para minimizar seu peso.

Antes do início dos ensaios com os fios, o sistema foi calibrado com o objetivo de verificar a influência da rigidez do deflectômetro nos resultados. 


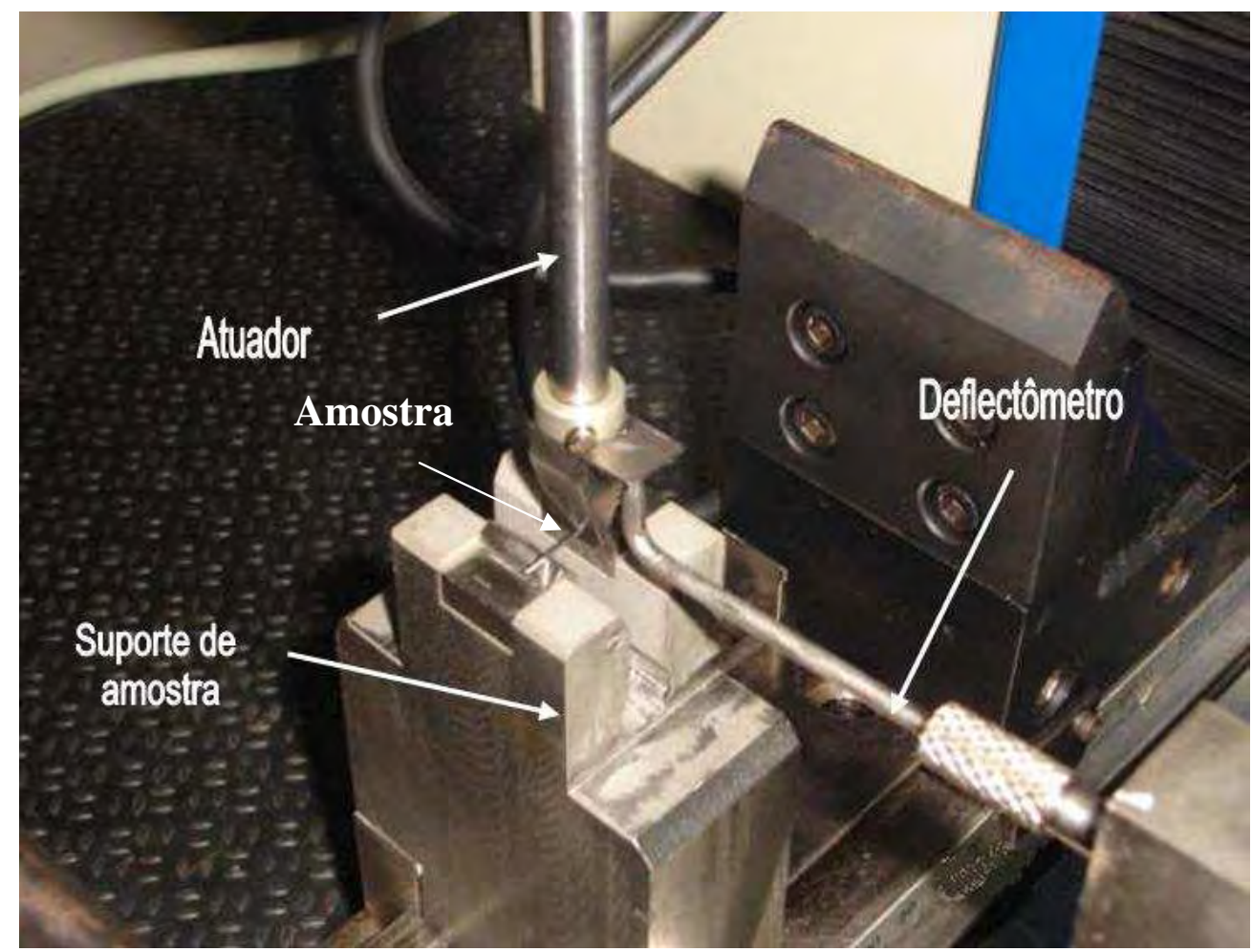

Figura 28 - Vista superior do sistema para teste de flexão em três pontos em amostras de fios de NiTi

Os ensaios de flexão em três pontos realizados nas amostras de NiTi são mostrados nas figuras 29 ( a) e (b).

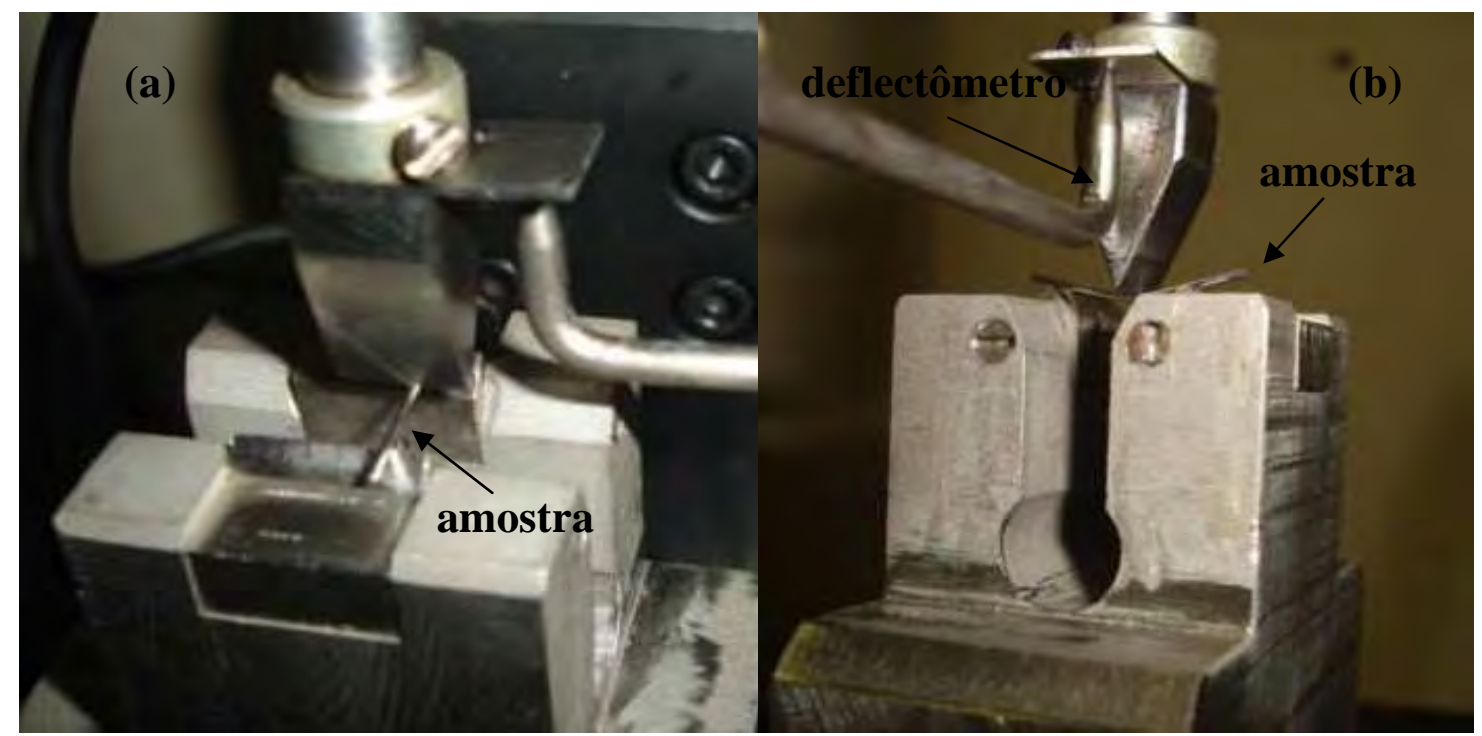

Figura 29 (a) e (b) - Ensaio de flexão em três pontos em amostras NiTi 
Foi necessário fazer uma nova programação para que a aquisição de dados do ensaio fosse feita também na etapa de descarregamento, além dos dados obtidos no carregamento. Esse programa permite a entrada de dados da geometria corpo de prova, distância entre apoios, velocidade do atuador, deflexão final, etc.

Os corpos de prova constituídos de fios termoativados foram submetidos ao ensaio de flexão, conforme metodologia estudada ADA $\mathrm{n}^{\circ} 32$, conforme pode ser observado na figura 30. Sendo assim, para os testes com os fios de NiTi termoativado foi construída uma câmara para simular a temperatura corporal. Com este objetivo foi acoplada uma cuba de acrílico, com travas, e vedação em silicone. A cuba de acrílico é transparente e permite uma boa visualização do ensaio. O sistema foi testado e os resultados mostraram que após ajustar a temperatura do conjunto em $37^{\circ} \mathrm{C}$ ocorreu uma variação inferior a $1{ }^{\circ} \mathrm{C}$ para um intervalo de 10 minutos. Considerando que o tempo de um ensaio é inferior a 7 minutos pode se garantir que a temperatura ficou constante durante os ensaios, por isso, não foi necessário utilizar um sistema de aquecimento auxiliar para manter a temperatura constante.

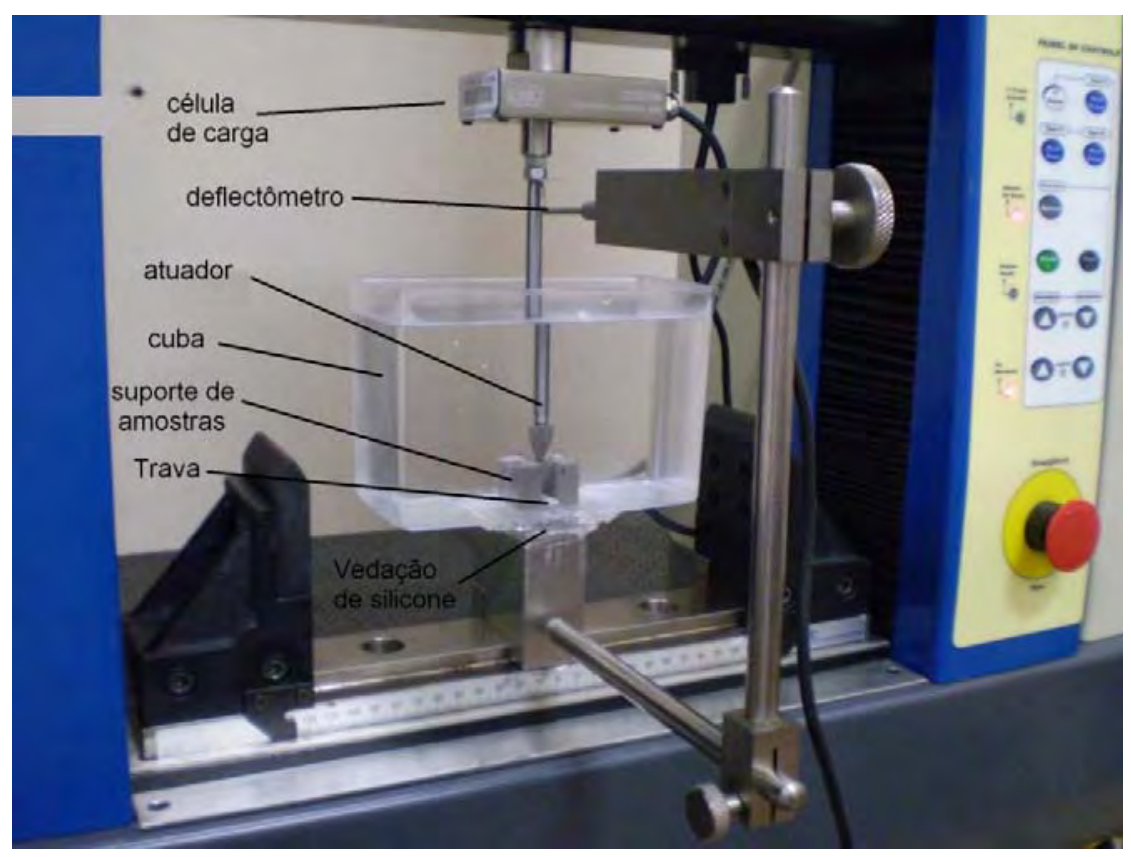

Figura 30 - Equipamento para o ensaio de flexão em três pontos para fios NiTi termoativado com sistema de temperatura 
Os ensaios de flexão em três pontos realizados nas amostras de NiTi termoativadas são demonstradas nas figuras 31 (a) e (b).

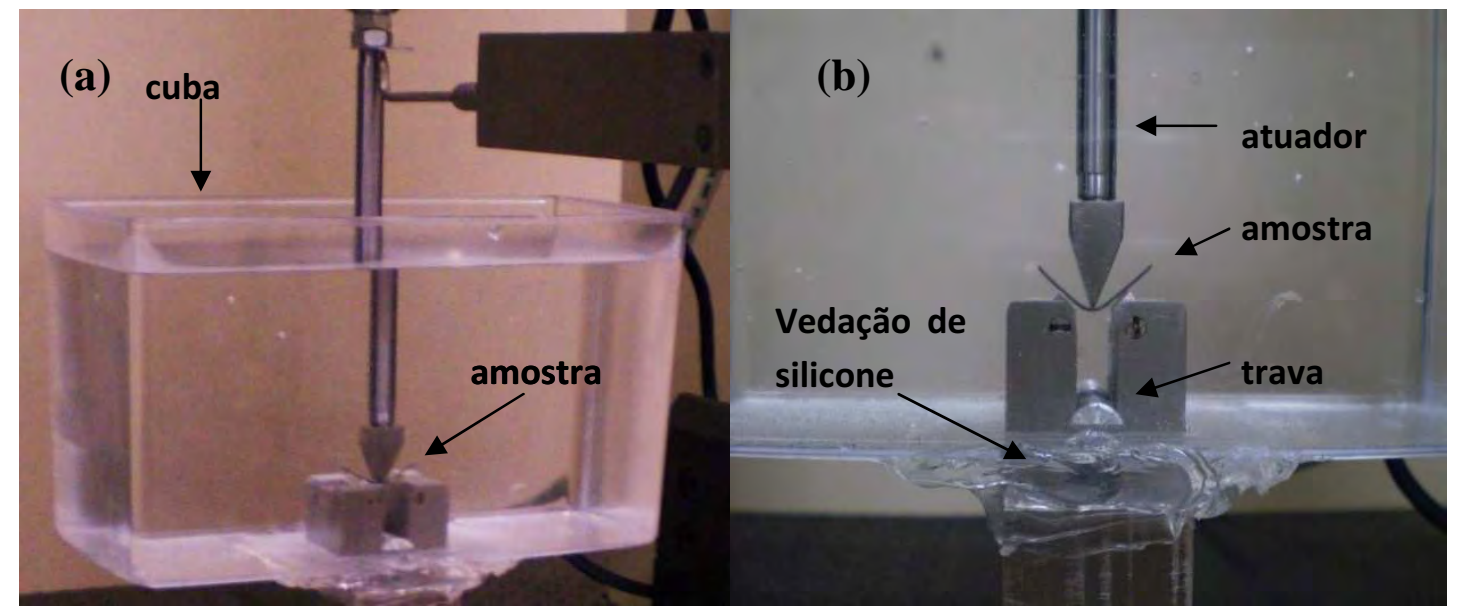

Figura 31 - (a) Ensaio de flexão em três pontos realizada em amostra de NiTi termoativada. (b) Detalhe do ensaio de flexão em três pontos em amostra NiTi termoativada

Os dados de força e deflexão adquiridos durante os ensaios mecânicos de flexão em três pontos foram traçados em forma de gráficos, conforme mostrado na figura 32. Em cada ensaio foram registradas as forças, durante $o$ descarregamento, correspondentes às seguintes deflexões: 0,5, 1, 2 e 3 mm.

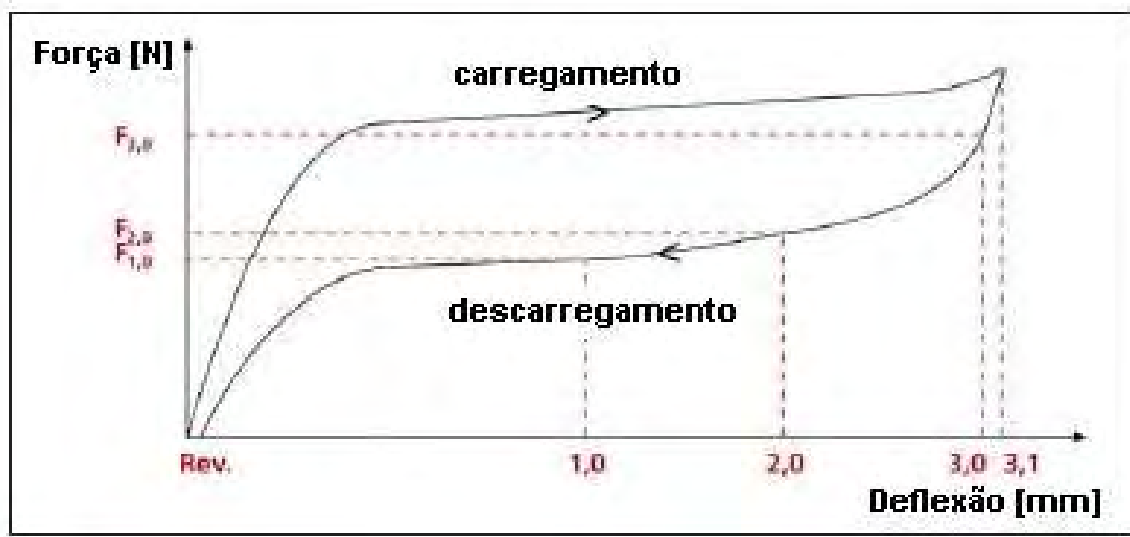

Figura 32 - Curva representativa do ensaio de flexão em três pontos

As formulações utilizadas na determinação das propriedades mecânicas baseiam-se na teoria aplicada a vigas sujeita à flexão em três pontos, considerando o material no regime elástico. 
O módulo de elasticidade $(E)$ foi obtido empregando-se a equação:

$$
E=\frac{L^{3} \Delta P}{4 b h^{3} \Delta Y}
$$

Em que: $\Delta P$ é o incremento da carga aplicada; $L$ é a distância entre apoios; $\Delta Y$ é o incremento de deflexão (flexa).

A tensão em flexão foi calculada usando a equação:

$$
\sigma=\frac{3 P L}{2 b h^{2}}
$$

A deformação foi obtida empregando-se a seguinte equação:

$$
\varepsilon=\frac{6 Y h}{L^{2}}
$$

Em que: $\varepsilon$ é a deformação na superfície externa; $\boldsymbol{Y}$ é a deflexão máxima (ou flexa). 


\section{RESULTADOS E DISCUSSÃO}

Neste trabalho foram realizadas deposições de filme de a-C:H, sobre amostras e também sobre arcos de NiTi superelástico e NiTi termoativado, com o objetivo de inibir a liberação de íons metálicos. Os filmes foram depositados pela técnica de deposição de vapor químico assistido por plasma - PECVD, utilizando-se radiofreqüência (13,56 MHz). Realizou-se a deposição do filme com a proporção de $30 \%$ de acetileno e $70 \%$ de argônio, com pressão constante igual a $10 \mathrm{~Pa}$. Investigou-se o efeito da deposição deste filme sobre as amostras e arcos por meio de ensaios de molhabilidade, perfilometria, Espectroscopia de Raman, Espectrofotometria de absorção atômica e Ensaio de flexão em três pontos.

\subsection{Caracterização dos filmes}

\subsubsection{Perfilometria}

A partir da realização do ensaio de perfilometria foi possível medir a espessura do filme de a-C:H, tomando-se a medida em seis pontos diferentes sobre a lâmina de vidro, obtendo-se o valor médio equivalente a $228,25 \mathrm{~nm}$ e $288,25 \mathrm{~nm}$ para o NiTi e NiTi termoativado, respectivamente. Como a função do filme era proteger as amostras do meio bucal a espessura foi considerada satisfatória.

\subsubsection{Espectroscopia Raman}

Os espectros foram deconvoluídos segundo método proposto por Robertson (2002), o qual consiste em fazer uma aproximação com número de gaussianas iguais ao número de bandas associadas a ligações $\mathrm{sp}^{3} \mathrm{e}^{2}$, respectivamente e, calcular a área relativa sob os picos (Fig. 33). 


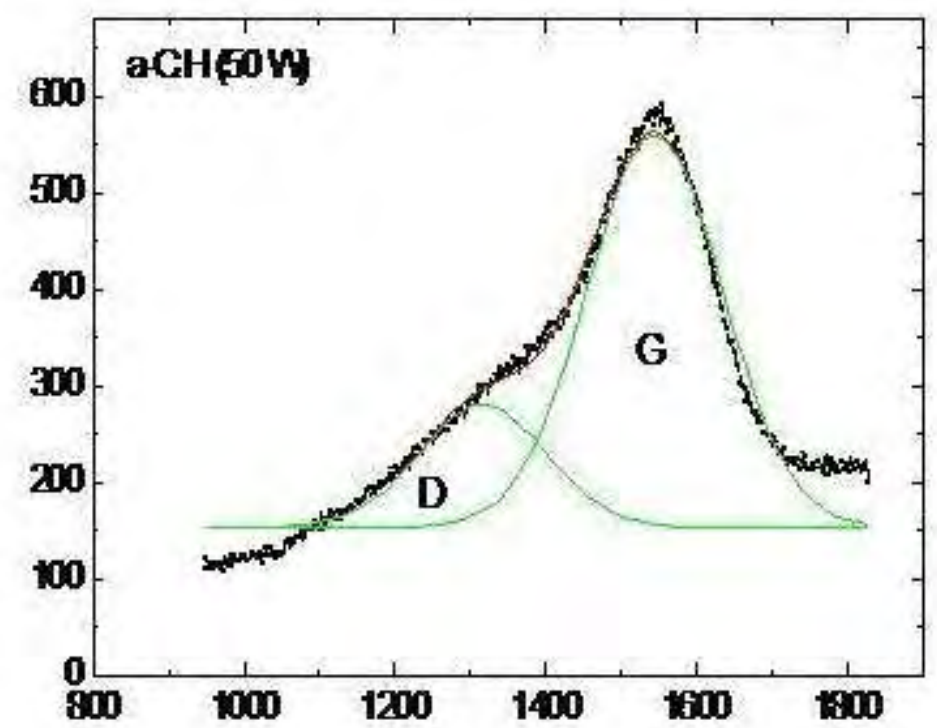

(a)

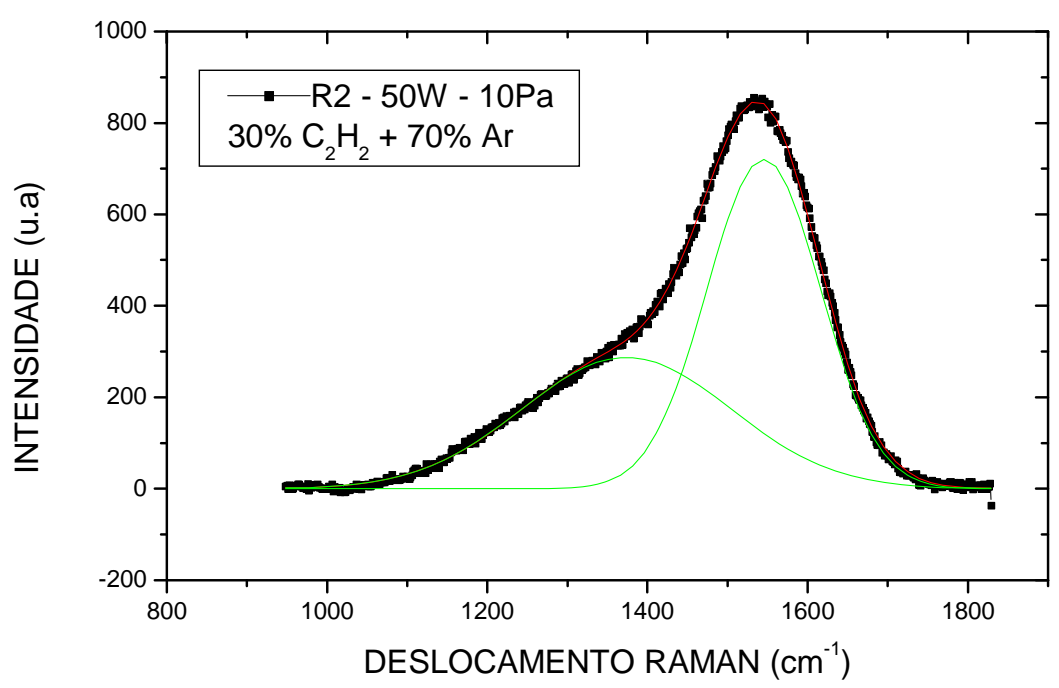

(b)

Figura 33- Espectro Raman obtido a partir de um filme de carbono amorfo hidrogenado (a-C:H) 
Para a liga NiTi a partir da análise do espectro verificou-se que os picos deconvoluídos D e G se localizam nas zonas de $1357,9 \mathrm{~cm}^{-1}$ e $1536,1 \mathrm{~cm}^{-1}$, respectivamente. A aparição do pico D revela que há uma desordem na estrutura grafítica, portanto trata-se de um filme amorfo. Além disso, quanto mais larga a linha do espectro Raman, mais amorfo o material se apresenta.

Da mesma forma o espectro obtido para o filme depositado sobre a liga termicamente ativada apresentou as bandas D e G nas zonas de 1373,8 e 1545,2 $\mathrm{cm}^{-1}$, respectivamente. Na tabela 2 é possível verificar os valores obtidos para $\mathrm{o}$ filme de a-C:H para os dois materiais estudados utilizando a potência de 50W.

Tabela 2 - Posição, largura e intensidade das bandas D e G do espectro do filme a-C:H para os dois materiais avaliados

\begin{tabular}{|c|c|c|c|c|c|c|}
\hline Potência (W) & \multicolumn{2}{|c|}{ Posição $\left(\mathrm{cm}^{-1}\right)$} & \multicolumn{2}{|c|}{ Largura $\left(\mathrm{cm}^{-1}\right)$} & \multicolumn{2}{|c|}{ Intensidade } \\
\hline 50 & Banda I & Banda $\mathrm{G}$ & Banda D & Banda G & Banda D & Banda $\mathrm{G}$ \\
\hline NiTi & 1357,9 & 1536,1 & 249,43 & 132,40 & 667,83 & 2501,7 \\
\hline NiTi termoativado & 1373,8 & 1545,2 & 261,27 & 141,77 & 287,27 & 720,51 \\
\hline
\end{tabular}

Para a liga NiTi a razão entre a intensidade das bandas $\left(\mathrm{I}_{\mathrm{D}} / \mathrm{I}_{\mathrm{G}}\right)$ do espectro do filme em função da potência foi equivalente a 0,26 e a taxa de deposição do filme em relação a potência foi de $0,76 \mathrm{~A} / \mathrm{s}$ [espessura do filme dividido pelo tempo de deposição $=(52,47 \mathrm{~nm} / 300 \mathrm{~s})]$. Para a liga termicamente ativada a razão entre a intensidade das bandas $\left(\mathrm{I}_{\mathrm{D}} / \mathrm{I}_{\mathrm{G}}\right)$ do espectro do filme em função da potência foi equivalente a 0,39 e a taxa de deposição do filme em relação à potência foi de $0,96 \mathrm{~A} / \mathrm{s}$ [espessura do filme dividido pelo tempo de deposição $=$ $(52,47 \mathrm{~nm} / 300 \mathrm{~s})]$. 


\subsubsection{Medida do ângulo de contato e energia de superfície}

Na tabela 3 é possível verificar os valores médios obtidos para o ângulo de contato das amostras estudadas.

Como o mesmo tratamento foi empregado para todas as amostras os valores do ângulo de contato foram bastante próximos. Superfícies que apresentam ângulos próximos a $90^{\circ}$ estão mais próximos de um caráter hidrofóbico do que hidrofílico, sendo esta propriedade interessante para aplicações onde não se deseja a adesão de placa bacteriana. Flint et al (2000) verificaram que para amostras confeccionadas com aço inoxidável houve uma maior adesão de bactérias para valores de ângulo de contato de aproximadamente $86^{\circ}$ e menor para superfícies com ângulos de $64^{\circ}$.

Tabela 3 - Valores médios do ângulo de contato

\begin{tabular}{c|cc}
\hline \multicolumn{2}{|c}{ Grupos avaliados } & Ângulo de contato \\
\hline $\begin{array}{c}\text { I } \\
\text { (fio de NiTi c/DLC) }\end{array}$ & 75,59 & $\pm 0,38$ \\
\hline $\begin{array}{c}\text { II } \\
\text { (fio de NiTi } \\
\text { termoativado c/ DLC) }\end{array}$ & $77,31 \quad \pm 0,24$ \\
\hline
\end{tabular}

Na figura 34 é possível observar o aspecto da gota durante a medida do ângulo de contato. 


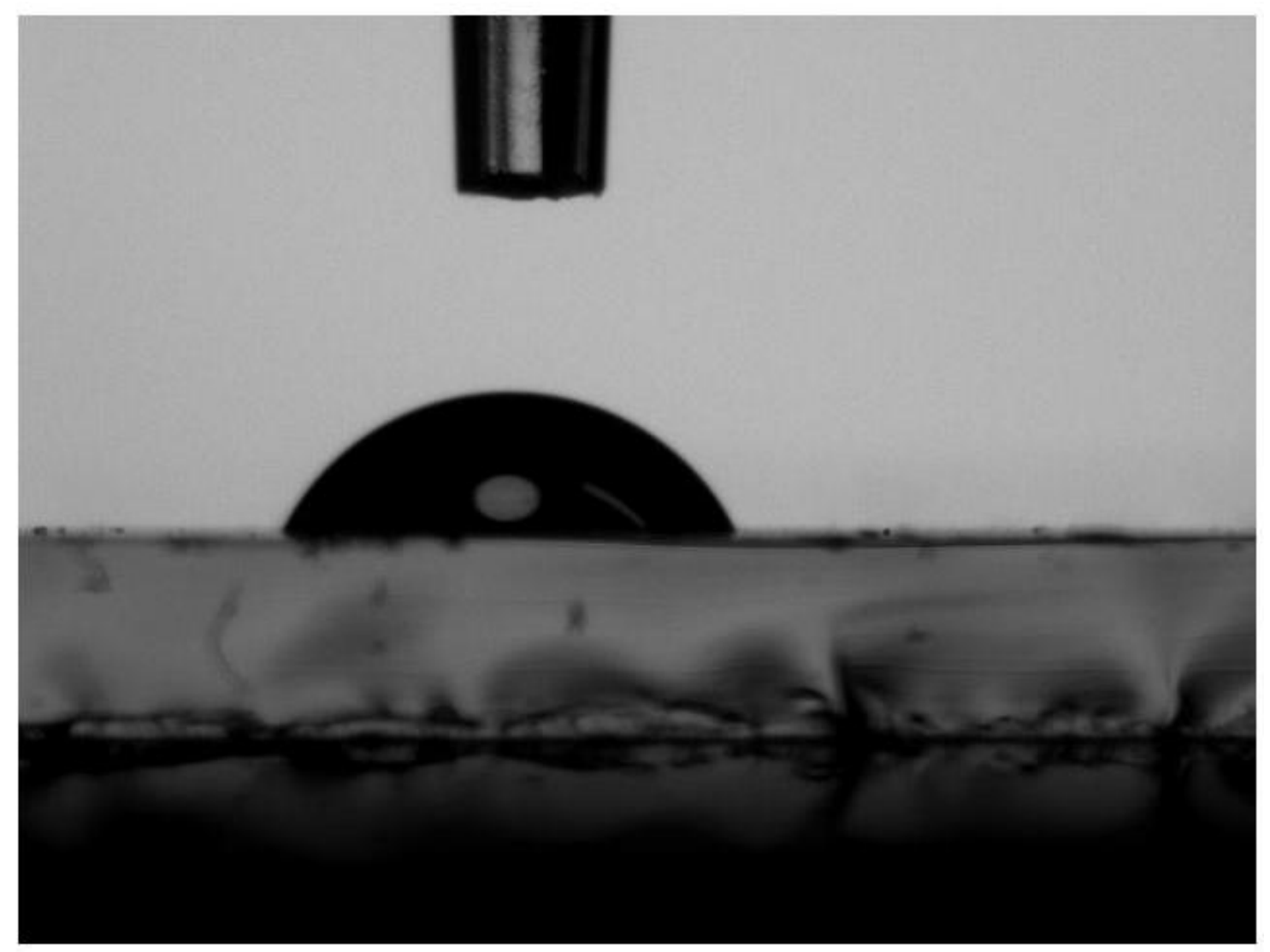

Figura 34 - Imagem da gota de água sobre o substrato com filme de a-C:H

\subsection{ENSAIO DE ESCOVAÇÃO}

$\mathrm{Na}$ figura 35 é possível observar os valores detectados para os íons níquel presentes na solução após a escovação associada à imersão em soro fisiológico por trinta dias. Os arcos do grupo controle ficaram apenas imersos em solução salina não tendo sido submetidos è escovação.

Comparando-se os dois materiais avaliados observa-se graficamente que a liberação de íons níquel foi maior no grupo da liga NiTi termicamente ativada para as três condições avaliadas. No entanto, verifica-se que para os dois materiais a presença de uma camada de DLC inibiu a liberação de íons níquel. Kobayashi (2005) 


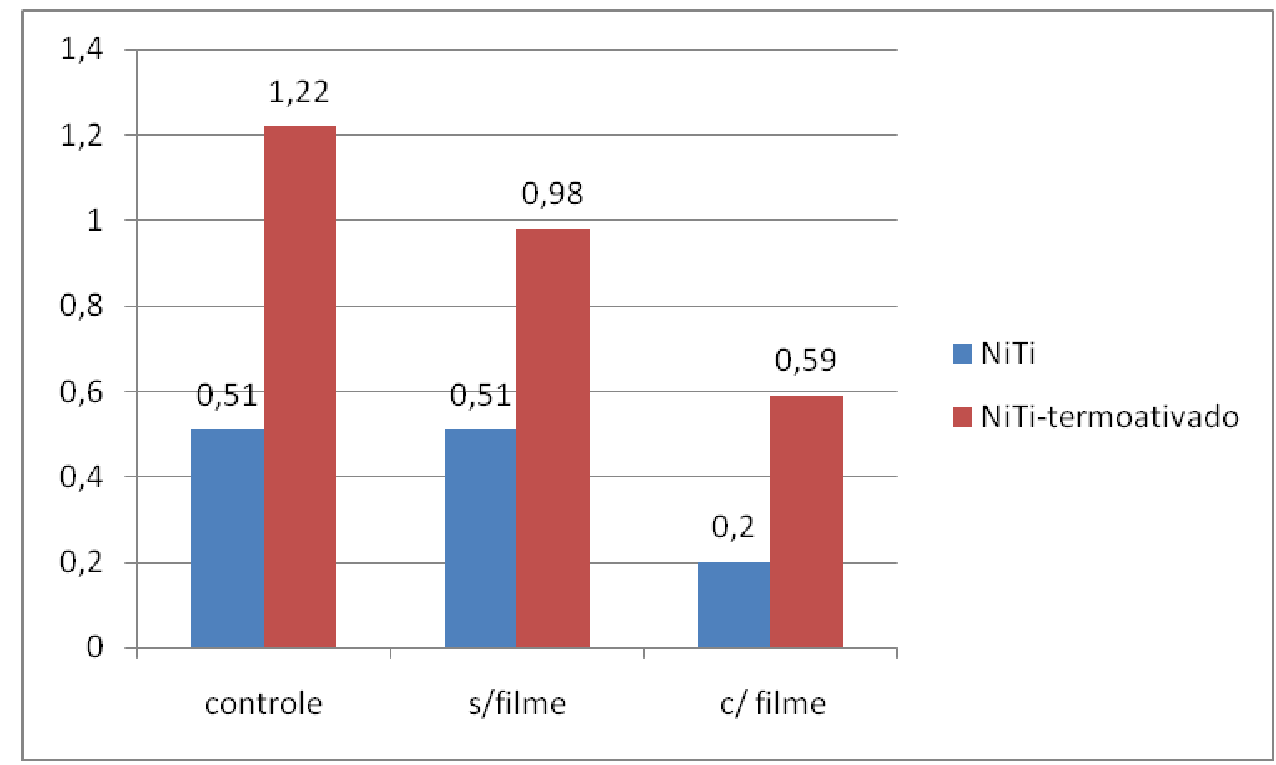

Figura 35 - Liberação de íons níquel para as duas ligas avaliadas

\subsection{ENSAIO DE FLEXÃO EM TRÊS PONTOS}

\subsubsection{Calibração do sistema de medidas}

Antes de começar os testes de funcionalidade com os fios, foi realizada uma aferição a fim de calibrar e verificar o efeito da rigidez do deflectômetro no resultado dos testes. Foi realizado um ensaio, sem nenhum fio, tomando-se os valores força- deflexão até uma amplitude de $3,1 \mathrm{~mm}$. O resultado está mostrado na figura 36.

É possível observar um comportamento linear tanto no carregamento quanto no descarregamento, obtendo-se uma constante linear de $0,118 \mathrm{~N} / \mathrm{mm}$ para calibração dos ensaios. 


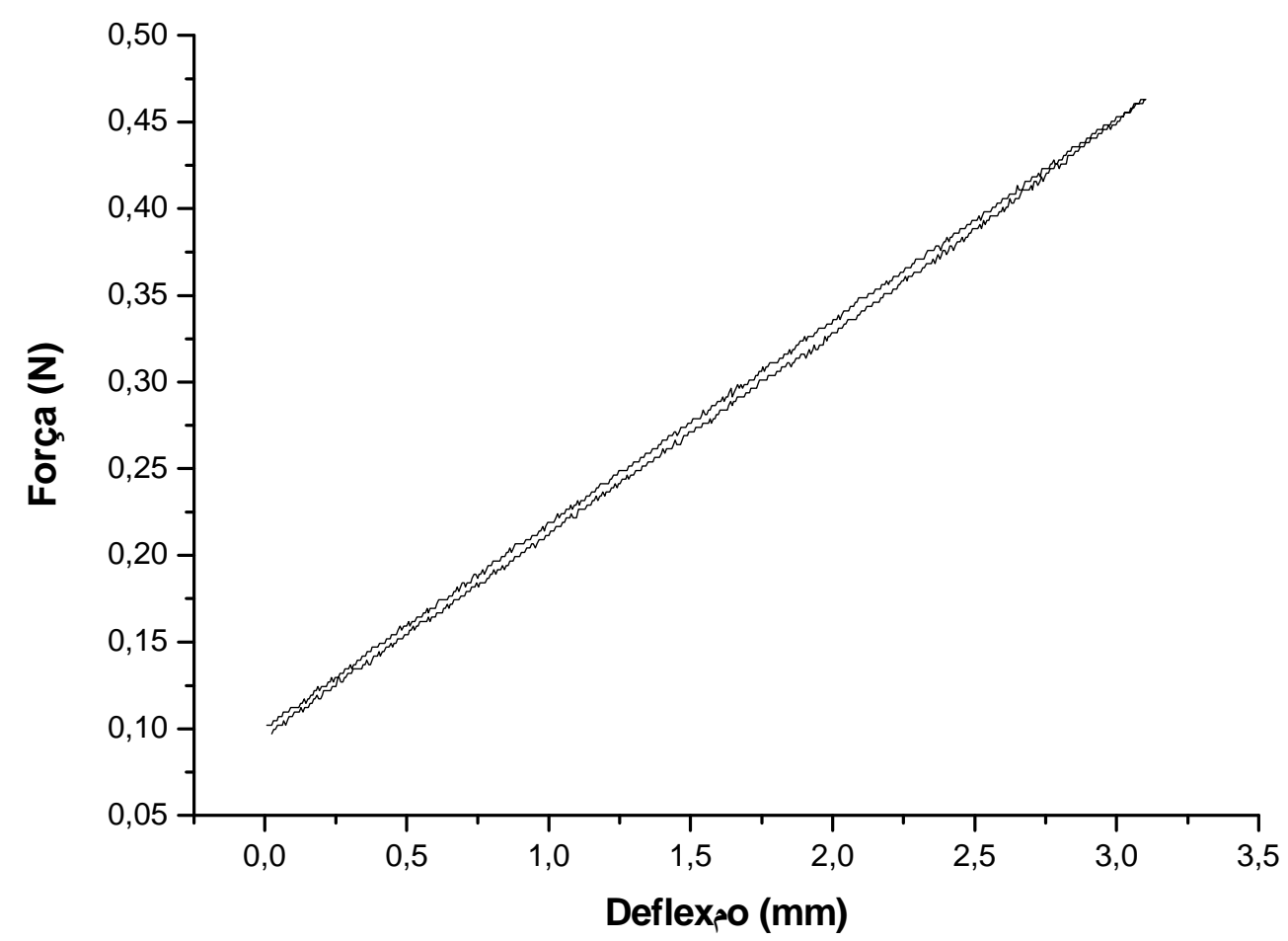

Figura 36- Curva força x deflexão de calibração obtida a partir do ensaio de flexão empregando-se deflectômetro eletrônico da EMIC

\subsubsection{Resultados dos ensaios de flexão}

$\mathrm{Na}$ figura 37 é possível observar as curvas representativas de força $\mathrm{x}$ deflexão para os fios superelásticos, nas duas condições avaliadas: com e sem deposição de a:C-H. Observa-se que em ambos os casos o material apresentou o laço de histerese não-linear característico do NiTi superelástico. O tratamento de superfície deslocou levemente a curva do fio tratado para cima sem comprometimento das propriedades superelásticas da liga.

A declividade da curva antes da transformação para martensita é constante indicando que o material é completamente austenítico antes da formação da martensita. 


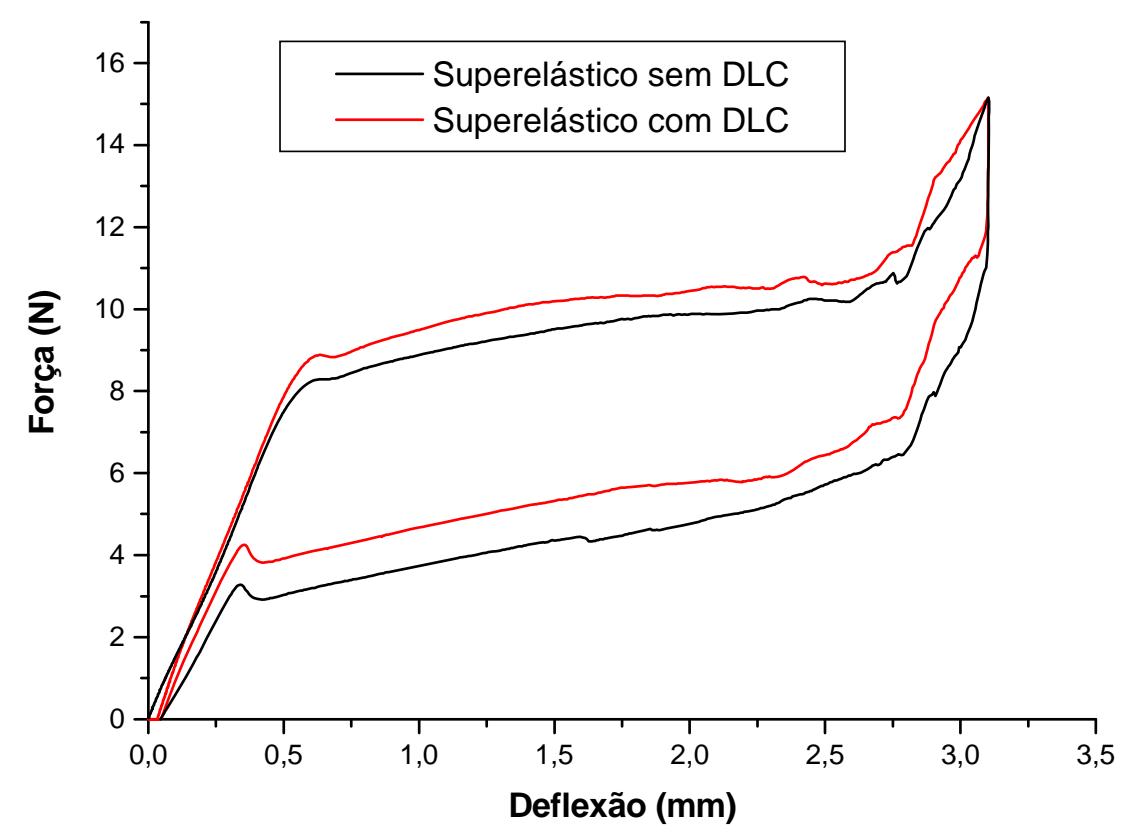

Figura 37 - Curva força x deflexão da liga NiTi com e sem tratamento de superfície

A histerese das amostras de NiTi superelástico sem DLC e com DLC, foi a mesma, verificando-se um aumento na tensão de ativação e desativação nas amostras com DLC. A completa transformação em martensita ocorreu a 1667 MPa e $1796 \mathrm{MPa}$, para a amostra não tratada e tratada, respectivamente. Sui et al (2006) observaram o mesmo comportamento para essas ligas após tratamento de superfície por imersão a plasma e concluíram que essas diferenças não são importantes para as aplicações a que esses materiais são destinados.

Para as amostras obtidas a partir de arcos de NiTi termoativados o comportamento mecânico verificado foi bastante interessante, conforme pode ser verificado na figura 38 . 


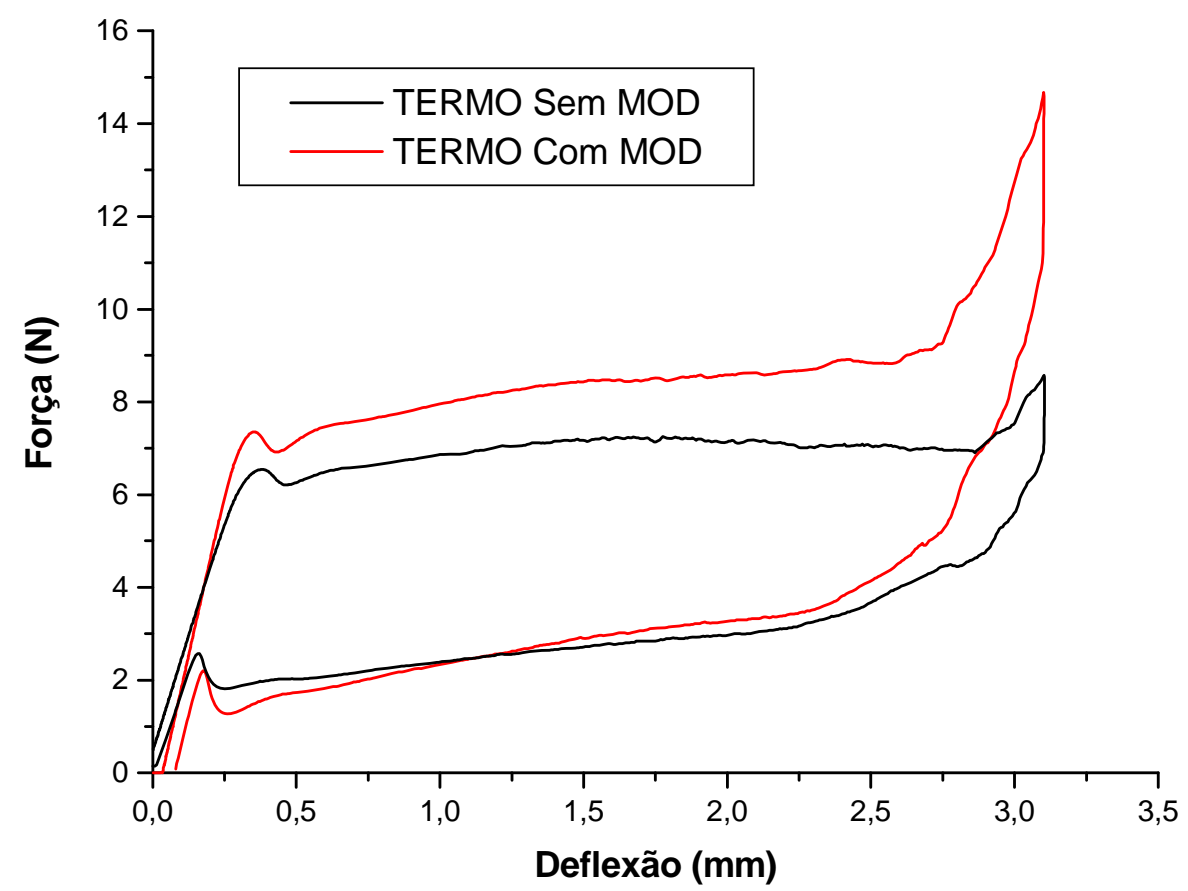

Figura 38 - Curva força x deflexão da liga NiTi termoativada com e sem tratamento de superfície

Para ambas as condições o comportamento mecânico deste material foi analisada, sendo que à temperatura de teste de $37{ }^{\circ} \mathrm{C}$, os materiais encontram-se inicialmente, antes de qualquer solicitação mecânica, na fase austenítica. No entanto, isso não inibiu a formação da martensita induzida por tensão durante o ensaio flexão, e as propriedades superelásticas do fio puderam ser observadas. Além disso, houve um pequeno aumento da força no patamar superior (força de ativação) para o fio com deposição, sendo que, no patamar inferior (região de desativação) manteve-se praticamente igual ao fio sem tratamento, e isso significa que a histerese é maior para o fio com deposição. Vale ressaltar que as forças de desativação é que são responsáveis na correção dos dentes.

Após o tratamento de superfície a declividade correspondente ao módulo de Young na região austenítica para o fio superelástico foi mais pronunciada não sendo verificado esse comportamento previamente. A diferença verificada entre os dois materiais (superelástico e termoativado) após tratamento deve-se a sua 
composição química, pois as ligas termoativadas apresentam cobre em sua composição levando a formação de uma fase intermediária romboedral denonimada fase $\mathrm{R}$.

A tabela 4 mostra os valores médios de força de desativação para deflexões $(\mathrm{mm})$ de $0.5,1.0,1.5,2.0,2.5$ e $3.0 \mathrm{~mm}$, para os fios superelásticos sem e com DLC e termoativados sem e com DLC.

Tabela 4 - Valores das forças de desativação em função para diferentes níveis de deflexão

\begin{tabular}{|c|c|c|c|c|c|c|}
\hline \multicolumn{7}{|c|}{ MÉDIA DAS FORÇAS (N) } \\
\hline Deflexão (mm) & $\mathbf{0 . 5}$ & $\mathbf{1 . 0}$ & $\mathbf{1 . 5}$ & $\mathbf{2 . 0}$ & $\mathbf{2 . 5}$ & 3.0 \\
\hline SUPER -S/DLC & $3.1 \pm 0.5$ & $3.8 \pm 0.5$ & $4.4 \pm 0.5$ & $4.8 \pm 0.5$ & $5.7 \pm 0.5$ & $9.4 \pm 0.2$ \\
\hline SUPER -C/DLC & $3.8 \pm 0.2$ & $4.5 \pm 0.2$ & $5.3 \pm 0.4$ & $5.7 \pm 0.5$ & $6.5 \pm 0.2$ & $10 \pm 0,6$ \\
\hline TERMO - S/DLC & $2.0 \pm 0.2$ & $2.4 \pm 0.2$ & $2.7 \pm 0.2$ & $2.9 \pm 0.2$ & $3.6 \pm 0.2$ & $5.6 \pm 0.1$ \\
\hline TERMO - C/DLC & $1.4 \pm 0.4$ & $2.0 \pm 0.4$ & $2.6 \pm 0.4$ & $3.0 \pm 0.3$ & $3.9 \pm 0.2$ & $8.5 \pm 0.3$ \\
\hline
\end{tabular}

Observa-se que os fios termoativados antes do tratamento de superfície apresentaram valores de ativação inferiores aos dos fios NiTi superelásticos. De acordo com Gravina (2007) clinicamente esse comportamento é interessante uma vez que quanto menores as cargas para se atingir os patamares constantes de ativação, com cargas mais suaves e constantes as ativações ocorrem.

Após o tratamento de superfície o valor de ativação foi superior para os fios superelásticos no início do patamar e superior em ambos os casos no final da deformação. Sui et al. (2006) verificaram comportamentos semelhantes após tratamento de superfície por imersão a plasma em fios superelásticos, no entanto, contrariamente ao preconizado por Gravina (2007) esses autores acreditam que a elevação nos valores de ativação não afetam o uso desses materiais.

Para obtenção dos valores de tensão e deformação correspondente ao carregamento em flexão foi utilizada a teoria aplicada a vigas sujeita à flexão em 
três pontos, considerando o material no regime elástico. O comportamento em flexão, dado em termos de tensão x deformação, é mostrado nas figuras 39 e 40. Para todos os materiais a deformação máxima foi de aproximadamente $6 \%$. $\mathrm{O}$ nível de tensão na fase de ativação em que a martensita começa a se formar induzida por tensão difere quanto ao aspecto de ser superelástico ou termoativado. Nos fios superelásticos essa tensão foi da ordem de $900 \mathrm{MPa}$, enquanto que, para os fios termoativados a tensão foi de aproximadamente 700 MPa.

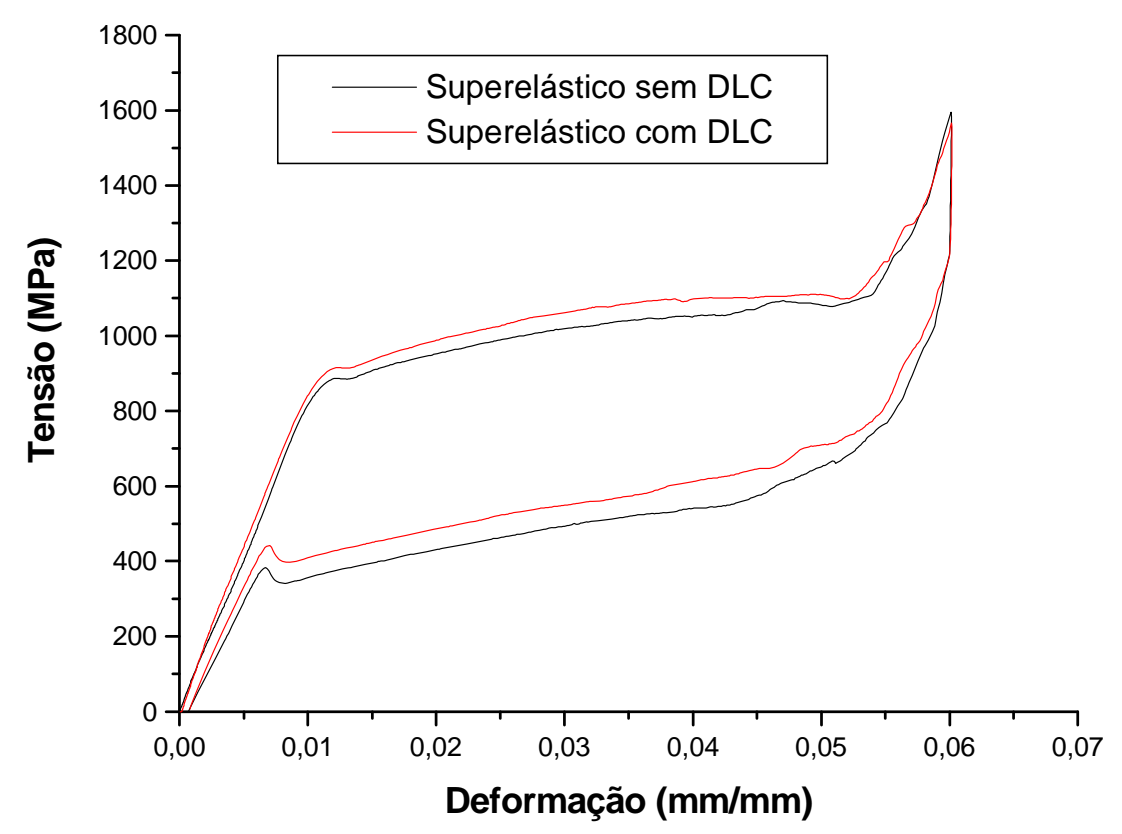

Figura 39 - Curva tensão x deformação da liga NiTi superelástica com e sem DLC 


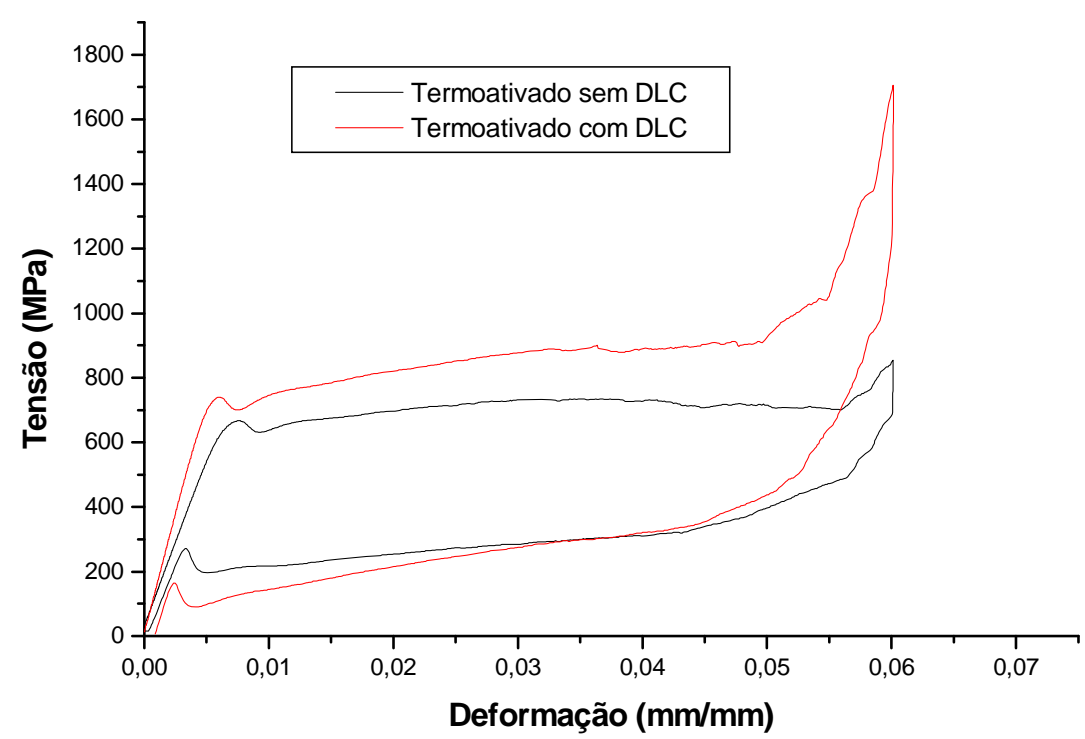

Figura 40 - Curva tensão x deformação da liga NiTi termoativada com e sem DLC

A tabela 5 mostra os valores médios de tensões (MPa) para deflexões (mm) de $0.5,1.0,1.5,2.0,2.5$ e $3.0 \mathrm{~mm}$, para os fios superelásticos sem e com DLC e termoativados sem e com DLC.

Tabela 5 - Valores médios de tensões (MPa) em função para diferentes níveis de deflexão

\begin{tabular}{|c|c|c|c|c|c|c|}
\hline \multicolumn{7}{|c|}{ MÉDIA DAS TENSÕES (MPa) } \\
\hline Deflexão $(\mathrm{mm})$ & 0.5 & 1.0 & 1.5 & 2.0 & 2.5 & 3.0 \\
\hline SUPER -S/DLC & $319 \pm 51$ & $391 \pm 51$ & $453 \pm 51$ & $494 \pm 51$ & $587 \pm 51$ & $968 \pm 21$ \\
\hline SUPER -C/DLC & $391 \pm 21$ & $463 \pm 31$ & $546 \pm 51$ & $587 \pm 51$ & $669 \pm 21$ & $1030 \pm 62$ \\
\hline TERMO - S/DLC & $206 \pm 21$ & $247 \pm 21$ & $278 \pm 21$ & $299 \pm 21$ & $371 \pm 21$ & $577 \pm 10$ \\
\hline TERMO - C/DLC & $144 \pm 41$ & $206 \pm 41$ & $268 \pm 41$ & $309 \pm 31$ & $401 \pm 21$ & $875 \pm 31$ \\
\hline
\end{tabular}

O patamar superior representa a tensão necessária para deformar o fio (ativação) e o patamar inferior o descarregamento. A declividade inicial e final é 
o módulo de Young das fases austenítica e martensítica, respectivamente. O tratamento de superfície não alterou a declividade da região inicial do fio superelástico, mantendo-se o valor do módulo de elasticidade em torno de 85 GPa. No entanto, o tratamento de superfície modificou a inclinação inicial da curva tensão x deformação do fio termoativado, que significa um aumento do módulo de elasticidade que apresentou um valor de $140 \mathrm{GPa}$. 


\section{CONCLUSÕES}

Com a realização desta pesquisa, conclui-se que:

- O emprego do tratamento de superfície com DLC propiciou menor liberação de íons para os dois materiais estudados;

- A espessura do filme de DLC para o NiTi superelástico e NiTi termoativado, foi suficiente para inibir a liberação de íons níquel protegendo as amostras do meio bucal;

- O tratamento de superfície foi mais efetivo para os materiais com comportamento superelástico. As forças de desativação para os fios superelásticos foram maiores que os termoativados, e os maiores valores foram obtidos para o superelástico com tratamento de superfície;

- A deposição do DLC promoveu aumento, tanto no carregamento quanto no descarregamento, das forças e das propriedades mecânicas das amostras. O tratamento de superfície alterou, mas não comprometeu as propriedades superelásticas dos fios. Comparando-se os fios superelásticos com e sem tratamento, verificou-se que naquele com tratamento de superfície, os patamares de ativação e desativação foi ligeiramente deslocado para cima, ou seja, teve um pequeno aumento de resistência à flexão. Para os temoativados, o fio com tratamento mostrou essa elevação de resistência à flexão, com maior destaque, apenas no patamar de ativação;

- O nível de tensão em que a martensita começa a se formar induzida por tensão difere quanto ao aspecto de ser superelástico ou termoativado. Verificou-se que essa diferença foi de aproximadamente $200 \mathrm{MPa}$, ou seja, nos fios superelásticos essa tensão foi da ordem de $900 \mathrm{MPa}$, enquanto que, para os fios termoativados a tensão foi de aproximadamente $700 \mathrm{MPa}$;

- O tratamento de superfície aumentou o módulo de elasticidade da fase austenita do fio de NiTi termoativado; 
- A temperatura empregada na esterilização das amostras para deposição do DLC afetou as propriedades das ligas termoativadas. 


\section{REFERÊNCIAS BIBLIOGRÁFICAS}

ACKERMAN JL., CHANDA LH., CREEKMORE TD., MEYER M., NESON, GD. Round table - Nitinol wire. Journal of Clinical Orthodontics, USA. v.12, n.7, p. 479-85, jul. 1978.

AMERICAN DENTAL ASSOCIATION. American National Standard/American Dental Association Specification n 32:orthodontic wires. Chicago. ADA. 2000.

AL-MAYOUF, A.M., AL-SWAYIH A. A., AL-MOBARAK N. A., ALJABAB A. S. Corrosion behavior of a new titanium alloy for dental implant applications in fluoride media. Materials Chemistry and Physics. v.86, n.2-3, p.320-29, aug. 2004.

ANDRADE, A.P.P.F, SATO, C., KOZEL, J.A., Fios ortodônticos de última geração. Sociedade Paulista de Ortodontia. Disponível em: http://www.spo.org.br/det_texto_odonto.php?id_texto_odonto=128. Acesso em: 17/02/2007.

ARRUDA, C.C. Análise mecanicodinâmica de ligas de Níquel-Titânio para aplicação ortodôntica. 2002. 70 p. Dissertação ( Mestrado Ciências Tecnologia Nuclear - Materiais) - Instituto de Pesquisas Energéticas e Nucleares, Universidade de São Paulo, 2002.

BRITTO, K.M.F., MARTINELLI, A.E., SCATENA JR., H., NASCIMENTO, R.M. Avaliação eletroquímica e mecânica de fios ortodônticos de NiTi em função do tempo de uso clínico. In: Congresso Brasileiro de Engenharia e Ciências dos Materiais, 16, 2004. Porto Alegre. Anais do 16ํㅡㄹCIMATCongresso Brasileiro de Engenharia e Ciências dos Materiais. 
BOYAN, B.D., LOSSDORFER, S., WANG, L., ZHAO, G., LOHMANN, C.H.,COCHRAN, D.L., SCHWARTZ,Z. Osteoblasts generate an osteogenic microenvironment when grown on surfaces with rough microtopographies. European Cells \& Materials Journal, v. 5, n.2, p.11-12, jul. 2003.

BUCCI, L.; CÂNDIDO, L.;GOMES, J.A.C.P. Avaliação da resistência a corrosão de fios ortodônticos Ni-Ti em saliva sintética contendo gel flúor acidulado. In: Conferência sobre Tecnologia e Equipamentos. 7, 2003. Florianópolis. Anais da $7^{\circ}$ Conferência sobre Tecnologia e Equipamentos.

CASIRAGHI, C., FERRARI, A.C., ROBERTSON, J. Raman spectroscopy of hydrogenated amorphous carbons. Physical review B, v.72, p. 085401 - 15, 2005 .

CHEN R, ZHI YF, ARVYSTAS MG. Advanced Chinese NiTi alloy wire and clinical observations. Angle Orthodontist, USA, v.62, n.1, p.59-66, mar. 1992.

CLARKE B., CARROLL W., ROCHEV Y., HYNES M., BRADLEY D., PLUMLEY D. Influence of Nitinol wire surface treatment on oxide thickness and composition and its subsequent effect on corrosion resistance and nickel ion release Journal of Biomedical Materials Research , USA, v.79, n.1, p. 61-70, oct. 2006.

DAYANANDA E., SUBBA RAO. Effect of strain rate on properties of superelastic NiTi thin wires. Materials Science and Engineering A. v.486, p. 96-103, 2008.

DEARNALEY, G., ARPS, J.H. Biomedical applications of diamond-like carbon (DLC) coatings: A review . Surface \& Coatings Technology • v.200, p.2518 2524, 2005. 
ELIADES, T., ATHANASIOU, A.E. In vivo aging of orthodontic Alloy: implications for corrosion potential, niquel. Release, and biocompatibily. Angle Orthodontist, USA. v. 72, n. 3, p. 222-37, jun. 2002.

EliAdES, T., PRATSINIS, H., KLETSAS, D., ELIADES, G., MAKOU, M. Characterization and cytotoxicity of ions released from stainless steel and nickel-titanium orthodontics alloys. American Journal of Orthodontics \& Dentofacial Orthopedics, USA., v. 125, n.1, p.24-9, jan. 2004.

EL MEDAWAR, L., ROCHER. P., HORNEZ, J.C.,TRAISNEL, M.,BREME, J.,HILDEBRAND, H.F. Electrochemical and cytocompatibility assessment of Nitinol- memory shape alloy for orthodontic use. Biomolecular Engineering. Amsterdam. v.19, n.2-6, p.153-160, ago. 2002.

ERBSTOESZER, B., ARMSTRONG, B.,TAYA, M.,INOUE, K. Stabilization of the shape memory effect in NiTi: an experimental investigation. Scripta Materialia.v. 42, n.12, p.1145-1150. Jun.2000.

ES-SOUNI, M., ES-SOUNI, M. BRANDIES, H.F. On the transformation behaviour, mechanical properties and biocompatibility of two NiTi-based shape memory alloys: NiTi42 and NiTi42Cu7. Biomaterials. Guildford. v.22, n.15, p.2153-2161, aug. 2001.

ES-SOUNI, M., ES-SOUNI, M. BRANDIES, H.F. On the properties of two binary NiTi shape memory alloys. Effect of surface finish on the corrosion behavior and in vitro biocompatibility. Biomaterials. Guildford. v.23, n.14, p.2887-2894, jul. 2002.

EVANS, J.E.; BARTON, J.M.D.; LITTLE, E. G.; BROWN, I.A. Observations during mechanical testing of Nitinol. J. Mechanical Engineering Science. v. 222, Part C, p. 97-105, 2008. 
FERREIRA, F.A.C.V. Biomecânica do movimento dental.In: Ferreira, F.V. Ortodontia:Diagnóstico e Planejamento Clínico. $4^{\circ}$ Edição. São Paulo: Editora Artes Médicas, 2001,cap. 18, p.363-398.

FIGUEIRA N., SILVA T.M, CARMEZIM M.J., FERNANDES J.C.S. Corrosion behaviour of NiTi alloy. Electrochimica Acta, v.54, p. 921-926, 2009.

FLINT S.H., BROOKS J.D, BREMER P.J. Properties of the stainless steel substrate, influencing the adhesion of thermo-resistant streptococci. Journal of Food Engineering. v. 43, p. 235-242, 2000.

GEROLDO, A.C.B., NUNURA, C.R.N., SANTOS, C.A. Estudo e caracterização de fios de ligas NiTi empregados em aparelhos ortodônticos. In: Congresso Brasileiro de Engenharia e Ciências dos Materiais. 2008. Porto de GalinhasPernambuco. Anais do 18 CBECIMAT- Congresso Brasileiro de Engenharia e Ciências dos Materiais. Disponível em: www.cbecimat.com .br / trab_completos/302-177.doc.*

GHERSEL, H. Relação entre força e deflexão na ativação e desativação de fios ortodônticos de NiTi. 2005.159f. Tese (Doutorado em Odontologia Materiais Dentários) - Faculdade de Odontologia da Universidade de São Paulo, Universidade de São Paulo, São Paulo, 2005.

GIL, F.J.; PLANELL, J.A. Shape memory alloys for medical applications. Proc Instn. Mech. Engrs. v. 212 , part H, p.473-488, 1998.

GRAVINA, M.A. Propriedades mecânicas de fios de NiTi e CuNiTi com efeito de memória de forma utilizados em tratamentos ortodônticos. 2007. 120 f. Tese (Doutorando em Odontologia - Ortodontia)- Faculdade de Odontologia da Universidade do Estado do Rio de Janeiro, Universidade do Estado do Rio de Janeiro, Rio de Janeiro, 2007. 
GURGEL, J. A., RAMOS, A.L., KERR, S.D. Fios Ortodônticos. Revista DentalPress Ortodontia Ortopedia Facial, Maringá, v. 6, n. 4, p. 103-114, jul.-ago. 2001.

GOUVÊA, J.A.R., ILTMAN, A., CRUVINEL, L.B., MACEDO, D.T., CASTELETTI, L.C. Caracterização mecânica de fios ortodônticos de Nitinol. In: Congresso Brasileiro de Engenharia e Ciências dos Materiais. 2006. Foz do Iguaçu, Paraná. . Anais do 17 CBECIMAT- Congresso Brasileiro de Engenharia e Ciências dos Materiais.

HELSEN, J.A., BREME H.J. Metals as biomaterials. Editora John Wiley \& Sons, cap. 3, p. 73-100, 1998.

HENRIQUES, J.F.C, MACHADO, D. T, HAYASAKI, S.M., Tração ortodôntica com finalidades protética e estética. In: CARDOSO, R.J.A, GONÇALVES, E. A. N. Ortodontia e Ortopedia Funcional. $1{ }^{\circ}$ Edição. São Paulo: Editora Artes Médicas, 2002. v.01, cap.06, p. 104.

HUANG, H.H. Variation in corrosion resistance of Nickel-Titanium wires from different manufacturers. Angle Orthodontist, v.75, n.4, p. 661-665, 2005.

ITMAN, A., SANTOS, A.C.M.. SILVA, R.V., GOUVÊA, C.A. Propriedades mecânicas e morfologia da fratura de ligas de níquel-titânio. In: Congresso Brasileiro de Engenharia e Ciência dos Materiais, 18, 2008, Porto de GalinhasPernambuco. Anais do 18 CBECIMAT- Congresso Brasileiro de Engenharia e Ciência dos Materiais. Disponível:http://www.cbecimat.com.br/cbecimat/ resumos_metalicos2.asp?Id=184.

JAFARI, J.; ZEBARJAD, S.M.; SAJJADI, S.A.. Effect of pre-strain on microstructure $\mathrm{Ni}-\mathrm{Ti}$ orthodontic archwires. Materials Science and Engineering A. v. 473, p. 42-48, 2008. 
JONES, M.I.; MCCOLL, I.R.; GRANT, D.M.; PARKER, K.G.; PARKER, T.L. Protein adsorption and platelet attachment and activation,on TiN, TiC, and DLC coatings on titanium forcardiovascular applications. John Wiley \& Sons Inc., p.413-421, 2000.

KANEKO K., YOKOYAMA K., MORIYAMA K., ASAOKA K., SAKAI J., ASAOKA, K. Delayed fracture of beta titanium orthodontic wire in fluoride aqueous solution. Biomaterials, v.24, n.12, p. 2113-2120, may. 2003.

KANEKO K, YOKOYAMA K, MORIYAMA K., ASAOKA K, SAKAI J., Degradation in performance of orthodontic wires caused by hydrogen absorption during short-term immersion in $2.0 \%$ acidulated phosphate fluoride solution. Angle Orthodontist, USA. v.74, n.4, p. 487-95, ago. 2004.

KOBAYASHI, S., OHGOE, Y., OZEKI, K., SATO, K., SUMIYA, T., HIRAKURI, K.K., AOKI, H. Diamond-like carbon coatings on orthodontic archwires. Diamond and Related Materials. USA. v.14, n.3-7, p. 1094-1097, mar-july 2005.

LOBO, A. O., MARTIN A. A., ANTUNES E. F., TRAVA-AIROLDI V. J., CORAT E. J. Caracterização de materiais carbonosos por Espectroscopia Raman INPEePrint. Disponível em: www.sid.inpe.br/ yolanda/ 2004 /12. 08. 13.44 v1 2004-12-09.

MARINS, N. Depositação de carbono amorfo hidrogenado sobre instrumento de corte cirúrgico (lâmina de bisturi). 2003. 48 f. Dissertação (Mestrado em Bioengenharia) - Faculdade de Engenharia Biomédica, Universidade do Vale do Paraíba, São José dos Campos, 2003.

MARINS, E. C.; PROCACI, M. I. M. A. Fios ortodônticos metálicos: visão geral - caderno UniFOA- Edição Especial, maio 2008. 
MELING T.R., ODEGAARD, J. The effect of short-term temperature changes on superelastic nickel-titanium archwires active in orthodontic bending. American Journal of Orthodontics and Dentofacial Orthopedics. v.119, p. 263-273, 2001.

MENEZES, L.M., FREITAS, M.P.M., GONÇALVES, T.S.G. Biocompatibilidade dos materiais em Ortodontia: mito ou realidade? Revista DentalPress de Ortodontia e Ortopedia Facial. Maringá. v.14, n.2, mar-ap., 2009.

MOCKERS, O., DEROZE, D.,CAMPS, J. Citotoxicity of orthodontic bands, brackets and archwires in vitro. Dental Materials. v.18, n.4, p.311-317, june 2002.

MULLINS, W.S., BAGHY, M.D., NORMAN, T.I. Mechanical behavior of thermo responsive orthodontic archwires. Dental Materials., v.12, n. 5-6, p.308314, sep-nov.1996.

NOGUEIRA, P.M. Estudo da viabilidade da utilização de filmes de carbono tipo diamante como camada de revestimento interno em dutos de transporte de petróleo. Boletim Técnico Petróbras, Rio de Janeiro, v.45, n.2, p.66-113, abr./jun. 2002.

OLTJEN, J.M.; DUCANSON, M.G.; GHOSH, J.; NANDA, R.S.; CURRIER, G.F. Stiffness deflection behavior of select orthodontic wires. Angle Orthodontics. USA. v. 67, n.3, p. 209-214, jun. 1997.

PÉRTILE, L.B. Caracterização mecânica e eletroquímica in vitro e in vivo da liga NiTi. 2005.104 f. Dissertação ( Mestrado em Engenharia de Materiais) Universidade Federal de Santa Catarina, Florianópolis, 2005. 
RAHILLY, G., PRICE,N. Nickel allergy and orthodontics. Journal of Orthodontics. Oxford. v.30, n.2, p.171-74, jun. 2003.

RYHÄNEN, J. Biocompatibility evaluation of nickel-titanium shape memory alloy. 1999. 117f. Academic Dissertation- Departament of Surgery - Faculty of Medicine, University of Oulu. Finland.1999.

ROBERTSON, J. Diamond-like amorphous carbon. Materials Science \&Engineering R, USA, v.37, n. 4-6, p.129-281, may 2002.

ROBERTSON, S.W. On the Mechanical Properties and Microstructure of Nitinol for Biomedical Stent Applications. 2006. 108 p. Tese. (Doctor of Philosophy in Engineering-Materials Science and Engineering) - University of California, Berkeley, 2006.

RONDELLI, G., VICENTINI, B. Localized corrosion behaviour in simulated human body fluids of commercial NiTi orthodontic wires. Biomaterials, Guildford. v.20, n.8, p. 785-792, april 1999.

ROSANI, G.A. Fios ortodônticos, propriedades mecânicas e suas aplicações clínicas. Monografia. Faculdade de Odontologia da Universidade São Franscisco. 2001.

SANTORO, M., BESHERS, D.N. Nickel-titanium alloys: Stress-related temperature transitional range. American Journal of Orthodontics and Dentofacial Orthopedics. v. 118, n. 6, p. 685-692, dec. 2000.

SCHIFF, N., GROSGOGEAT, M.L., DALARD, F. Influence of fluorided mounthwashes on corrosion resistance of orthodontics wires. Biomaterials, Guildford. v.25, n.19, p.4535-4542, aug. 2004. 
SHABALOVSKAYA, S.A.; Surface, corrosion and biocompatibility aspects of Nitinol as an implant. Bio-Medical Materials and Engineering. v. 12, n.1, p. 69-109, 2002.

SIOSHANSI, P., TOBIN, E.J. Surface treatment of biomaterials by ion beam processes. Surface and Coatings Technology, v.83, n.1-3, p.175-182, set.1996.

SOUZA, S.A. Ensaios Mecânicos de Materiais Metálicos- Fundamentos Teóricos e Práticos. $5^{\circ}$ edição. São Paulo. Ed.Edgard Blücher. 1982.

STAFFOLANI, D., DAMIANI, F., LILLI, C., GUERRA, M., STAFFOLANI, N.J., BELCASTRO, S., LOCCI, P. Ion release from orthodontic appliances. Journal of de Dentistry, Guildford. v.27, n.6, p.449-54, aug.1999.

SUI, J.H.; CAI, W. Effect of diamond-like carbon (DLC) on the properties of the NiTi alloys. Diamond \& Related Materials. v.15, p. 1720-1726, 2006.

SUI, J.H.; CAI, W., LIU, L.H.; C, ZHAO, L.C. Surface characteristics and electrochemical corrosion behavior of NiTi coated with diamond-like carbon. Materials Science and Engineering A, v. 438-440, p. 639-642, 2006.

SUI , J.H.; GAO, Z.Y.; CAIA, W.; ZHANG, Z.G. DLC films fabricated by plasma immersion ion implantation and deposition on the NiTi alloys for improving their corrosion resistance and biocompatibility. Materials Science and Engineering A. v. 454-455,p. 472-476, 2007.

SUN, E.X., FINE, S., NOWAK, W.B. Electrochemical behavior of nitinol alloy in Ringer's solution. Journal of Materials Science: Materials in Medicine. Netherlands. v.13, p.959-964, 2002. 
VICENTE, G.C.M. Caracterização de filmes DLC com potencial de utilização em motores de combustão interna. 2005. 98f. Dissertação (Mestrado em Engenharia Mecânica -Tecnologia)- Universidade Federal do Paraná, Paraná, 2005.

WIDU, F., DHESCHER, D., JUNKER. R., BOURAUEL. C. Corrosion and biocompatibility of orthodontic wires. Journal of Materials Science : Materials in Medicine. Netherlands. v.10, p.275-281,1999.

YANG P.; HUANG N. , LENG Y.X., YAO Z.Q. , ZHOU H.F., MAITZ M., LENG Y., CHU P.K. Wettability and biocompatibility of nitrogen-doped hydrogenated amorphous carbon films: Effect of nitrogen. Nuclear Instruments and Methods in Physics Research B. v.242, p.22-25, 2006.

YANG, P.; KWOK, S.C.H.; FU, R.K.Y., LENG, Y.X.; WANG, J.; WAN, G.J.; HUANG, N.;. LENG, Y.; CHU, P.K. Structure and properties of annealed amorphous hydrogenated carbon $(\mathrm{a}-\mathrm{C}: \mathrm{H})$ films for biomedical applications. Surface and Coatings Technology. v.177 -178, p.747-751, 2004. 


\section{ANEXOS}

Curvas tensão $X$ deformação das amostras de NiTi superelástico sem modificação.

\section{AMOSTRA 1}

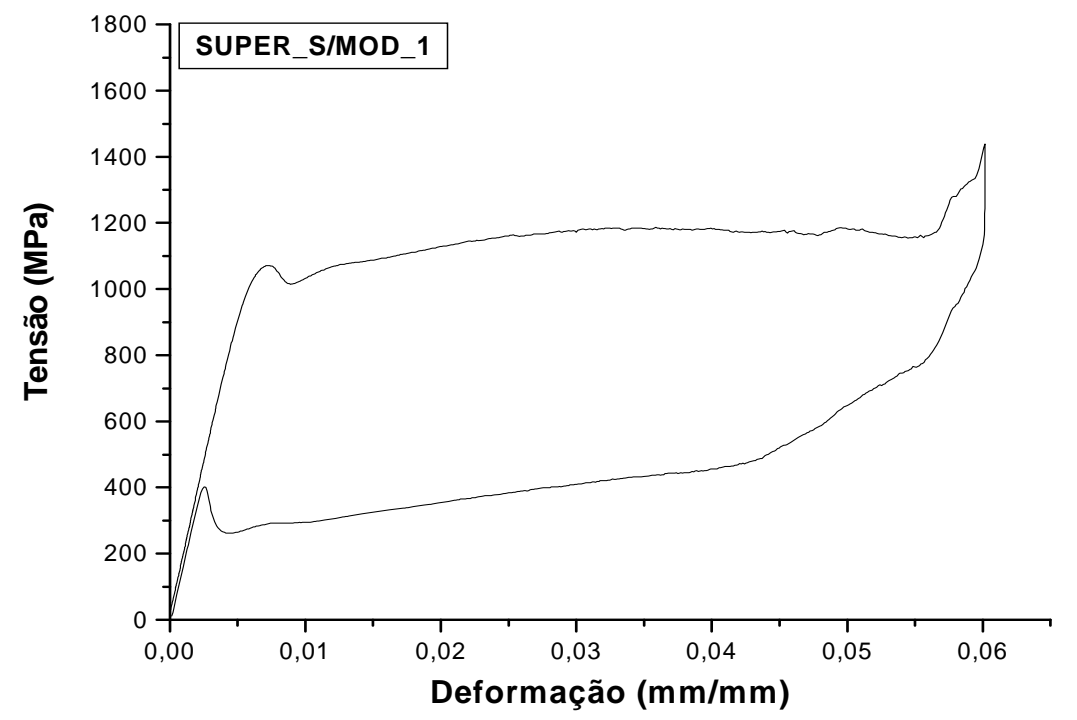

\section{AMOSTRA 2}

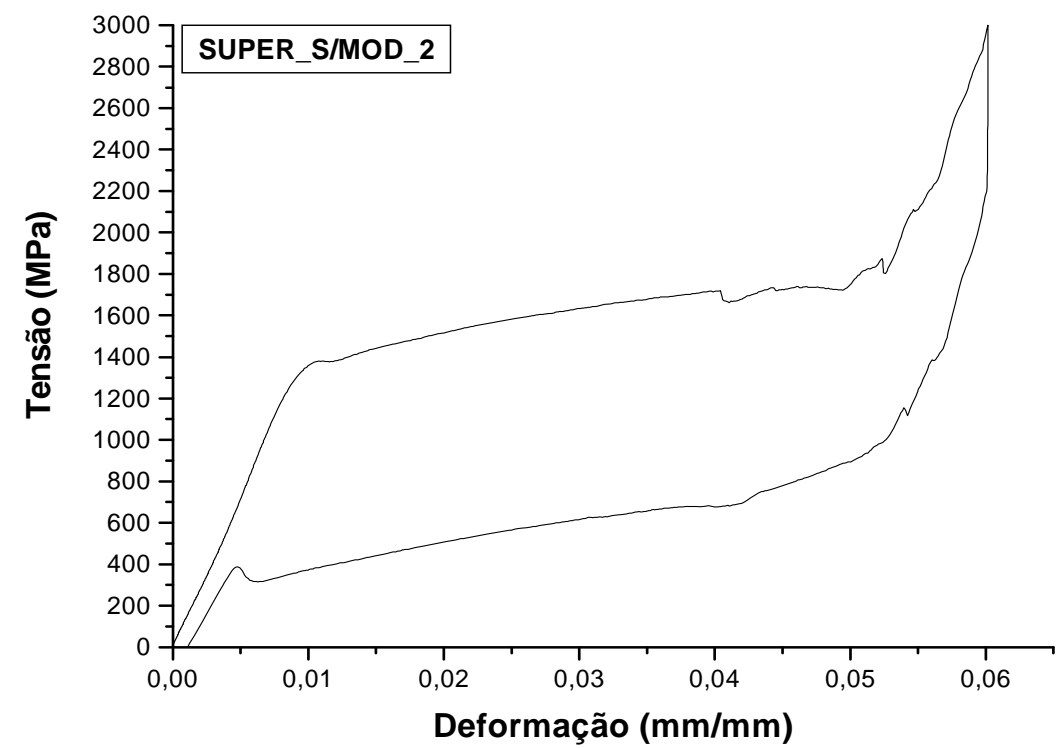




\section{AMOSTRA 3}

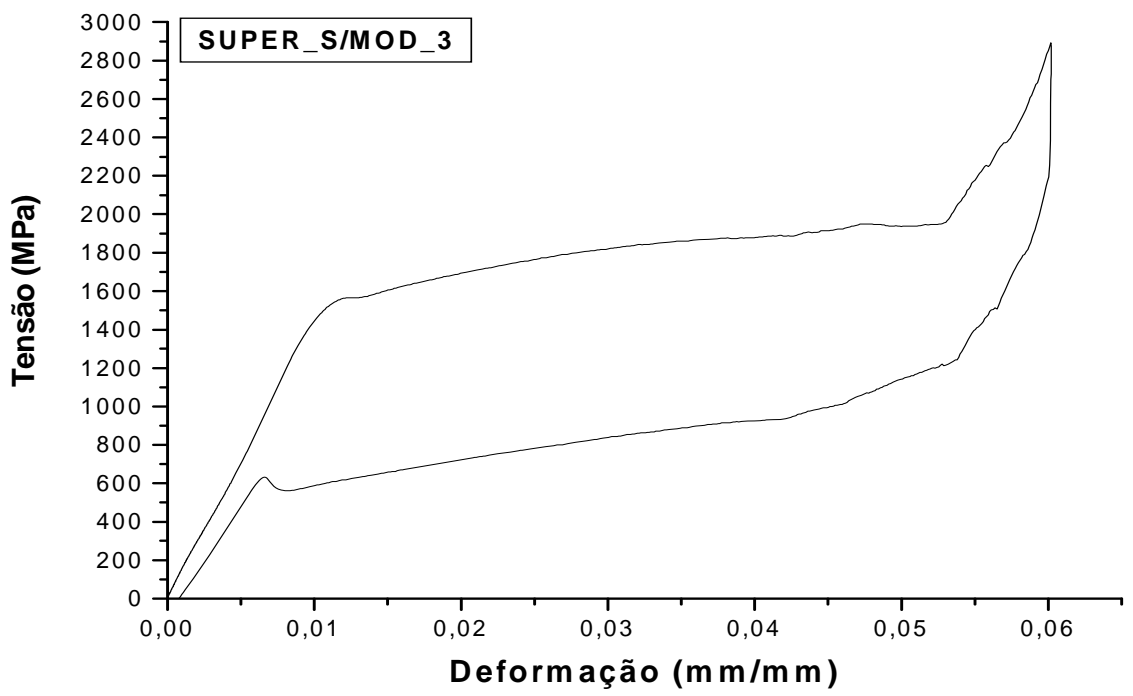

\section{AMOSTRA 4}

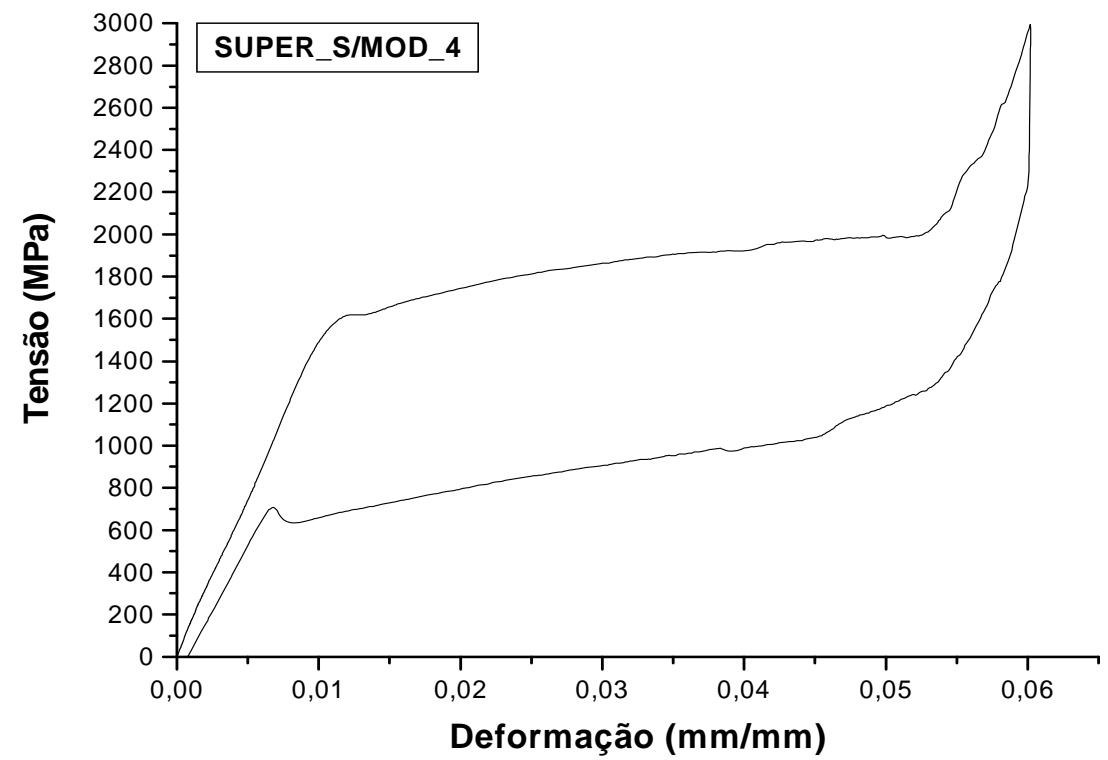




\section{AMOSTRA 5}

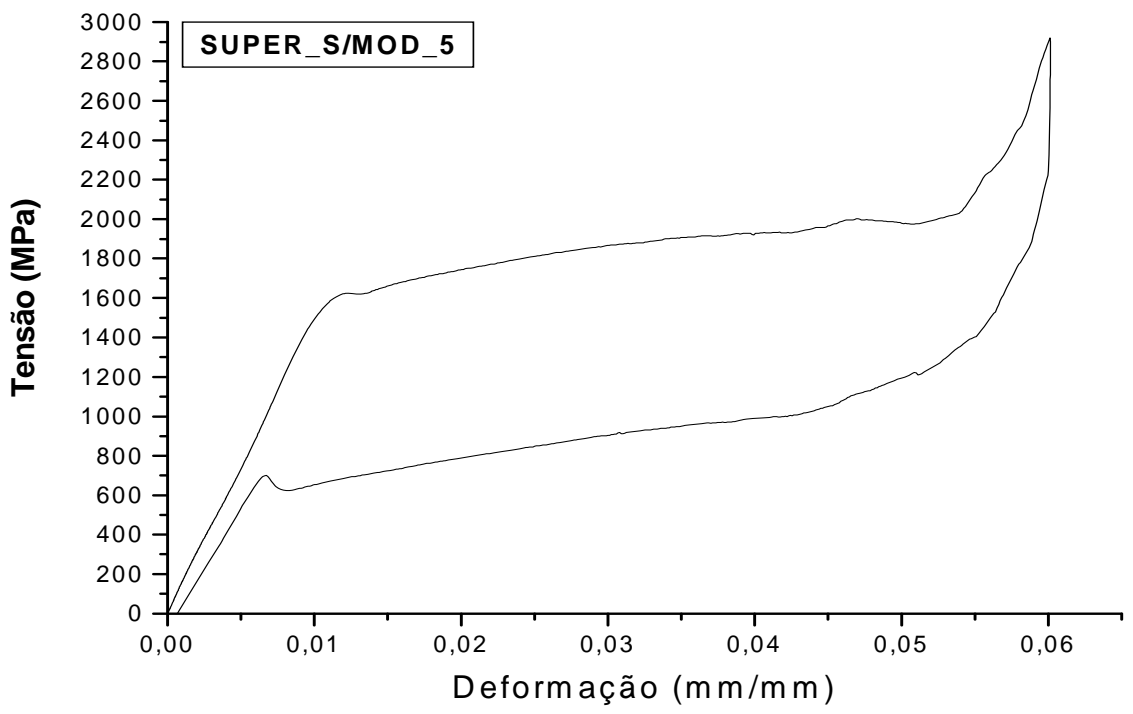

\section{AMOSTRA 6}

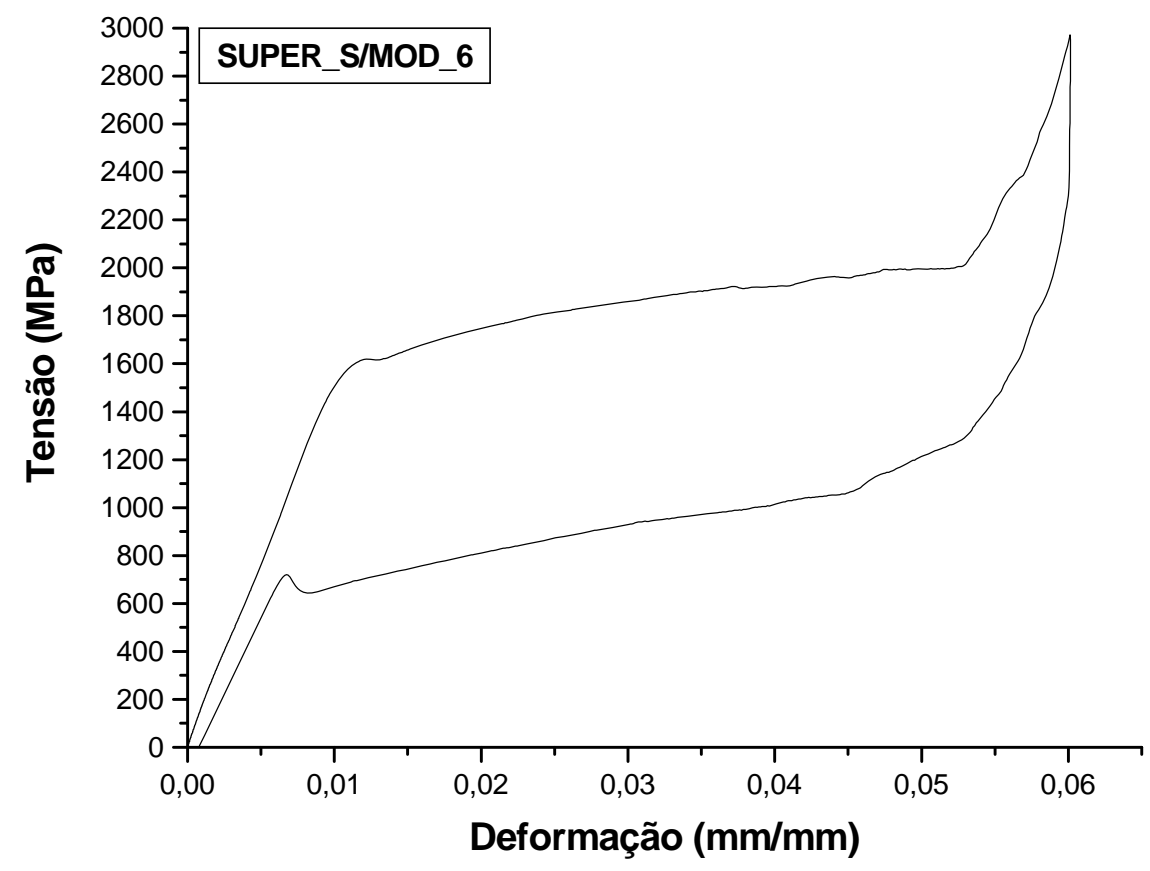




\section{AMOSTRA 7}

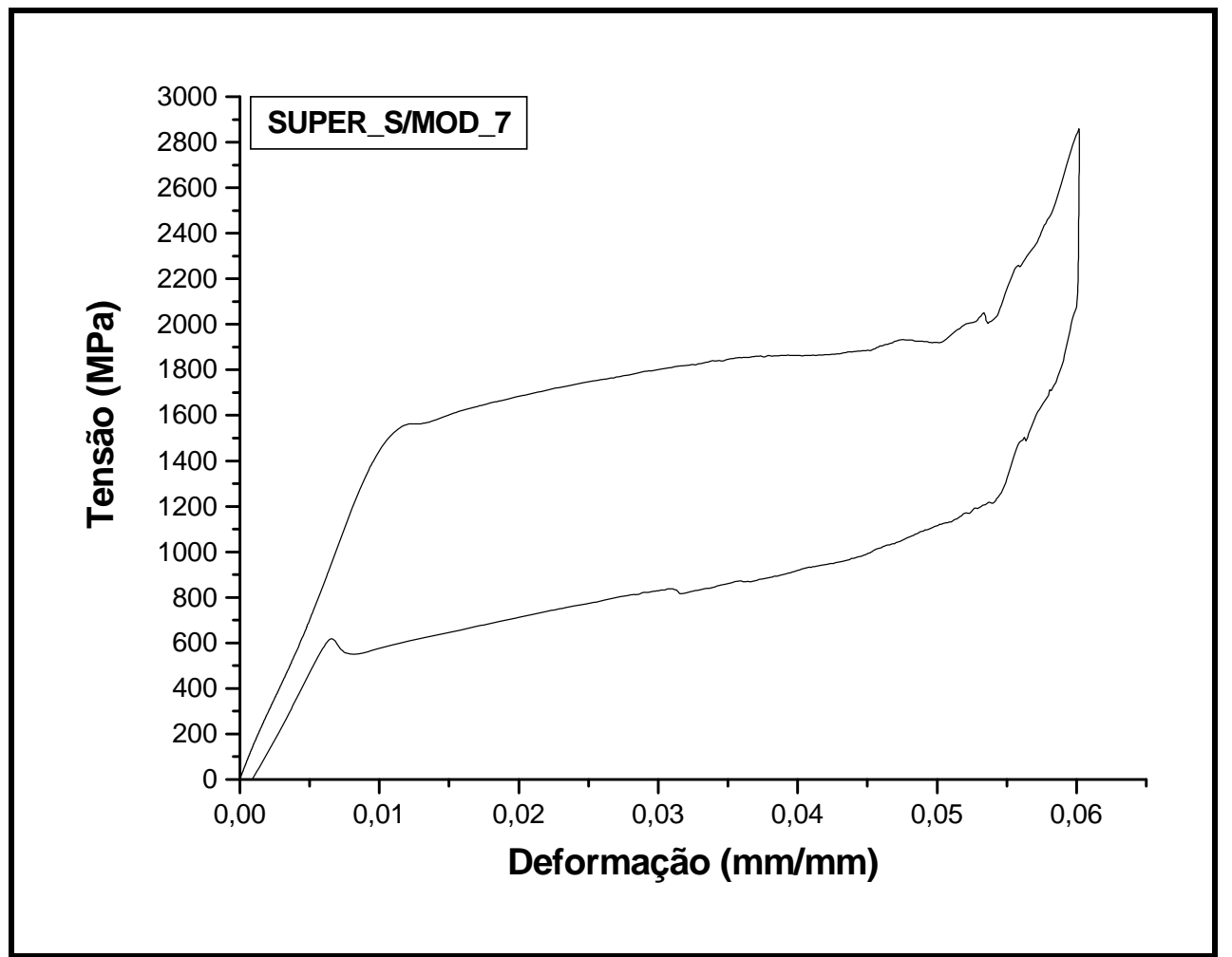

\section{AMOSTRA 8}

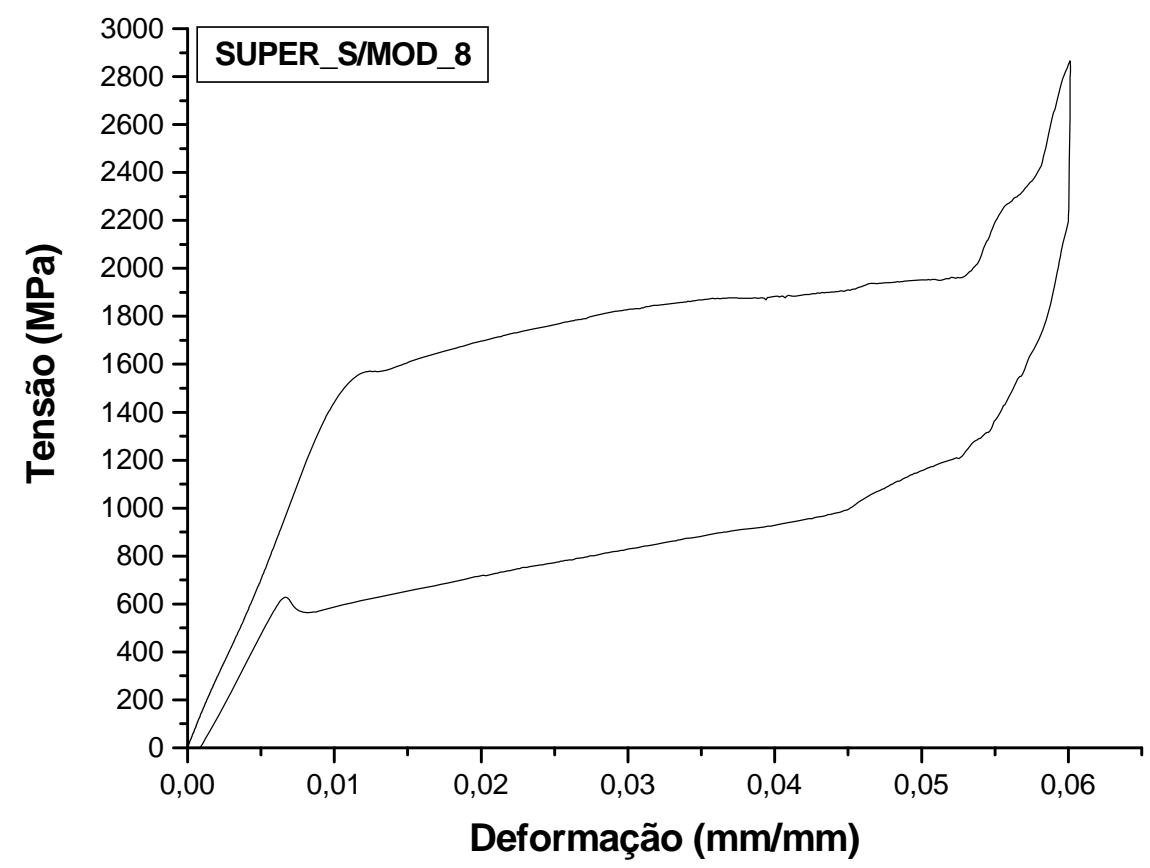




\section{AMOSTRA 9}

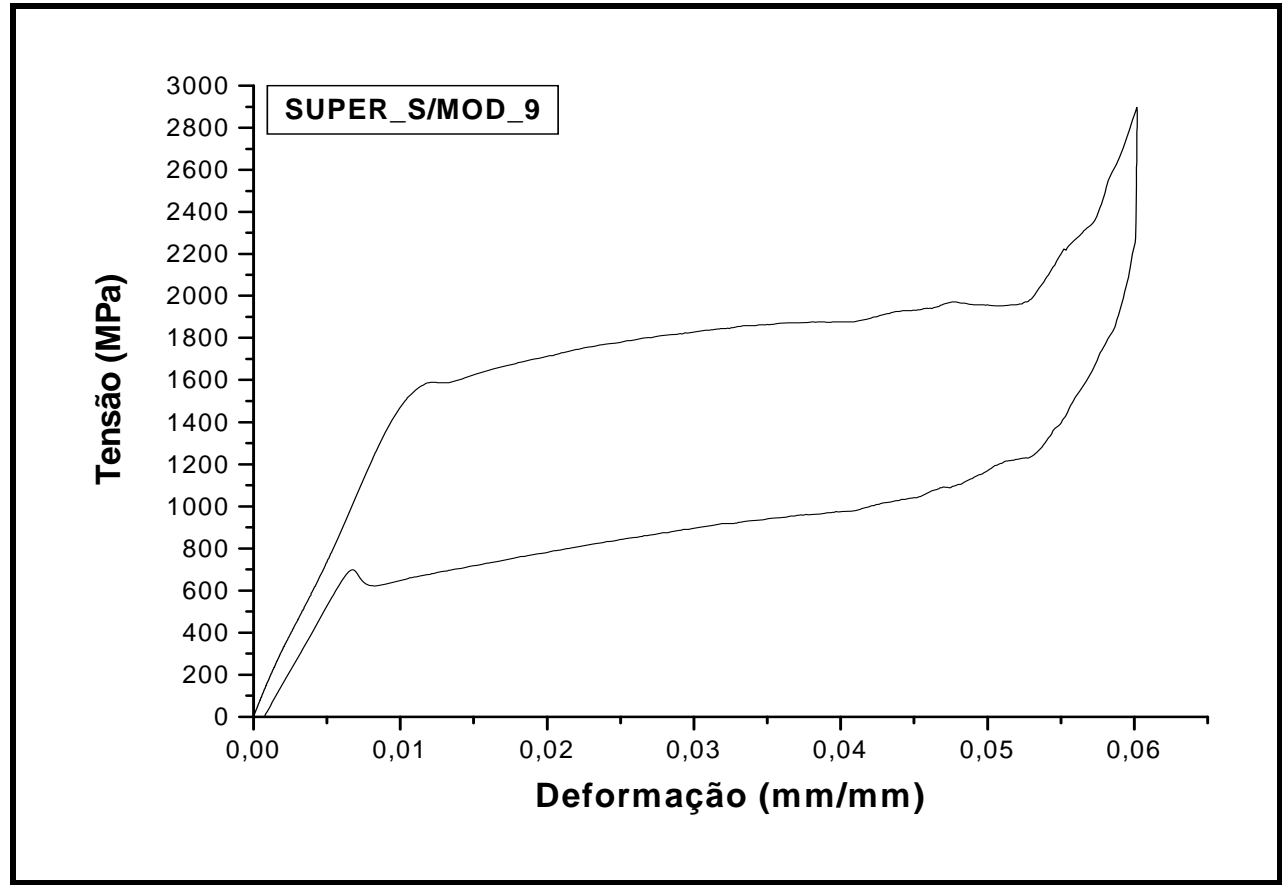

\section{AMOSTRA 10}

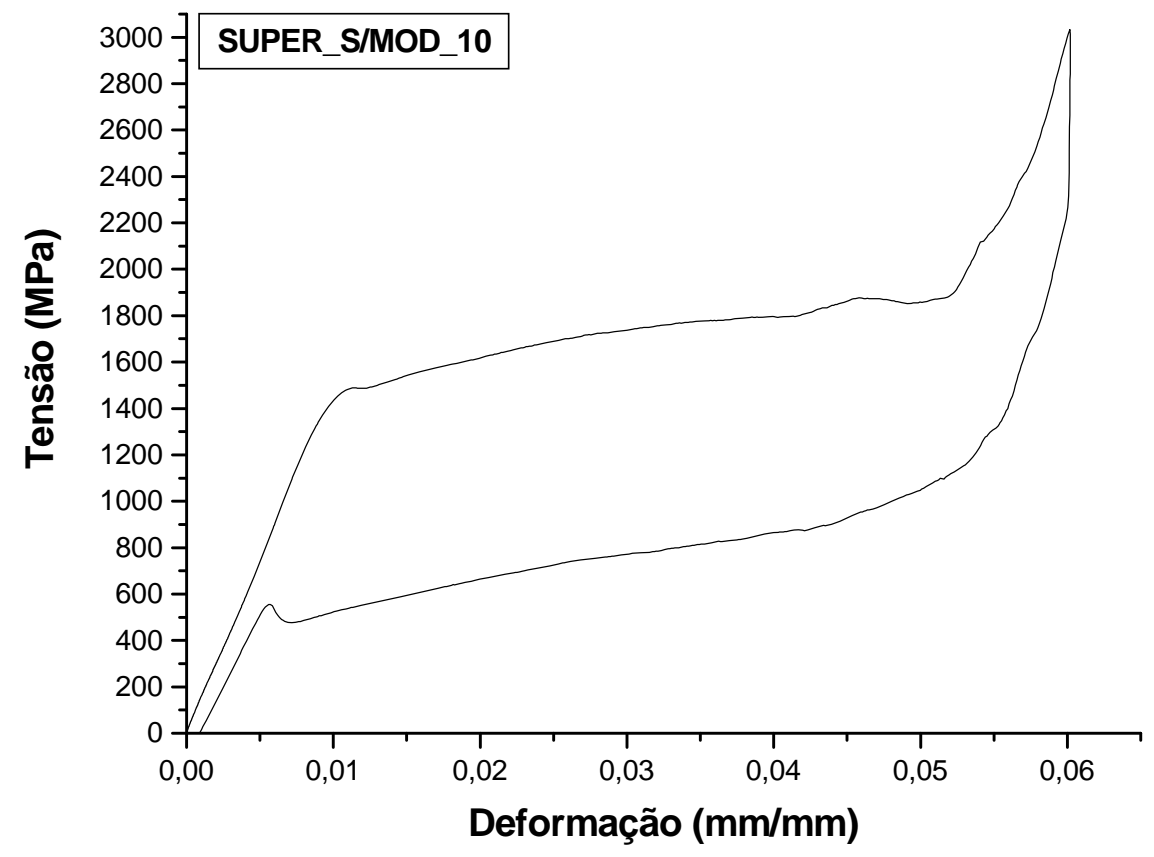


Curvas tensão $X$ deformação das amostras de NiTi superelástico com modificação

\section{AMOSTRA 1}

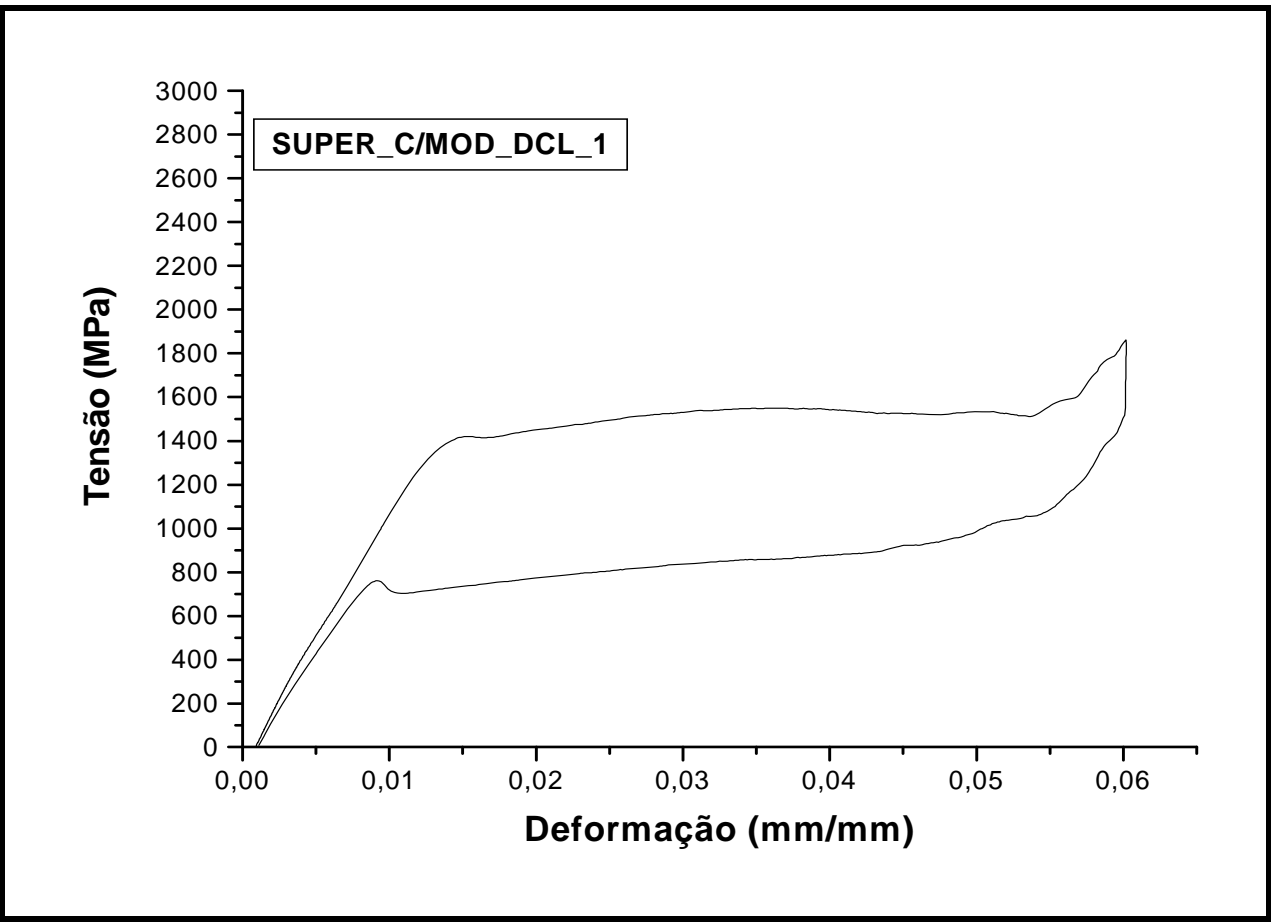

\section{AMOSTRA 2}

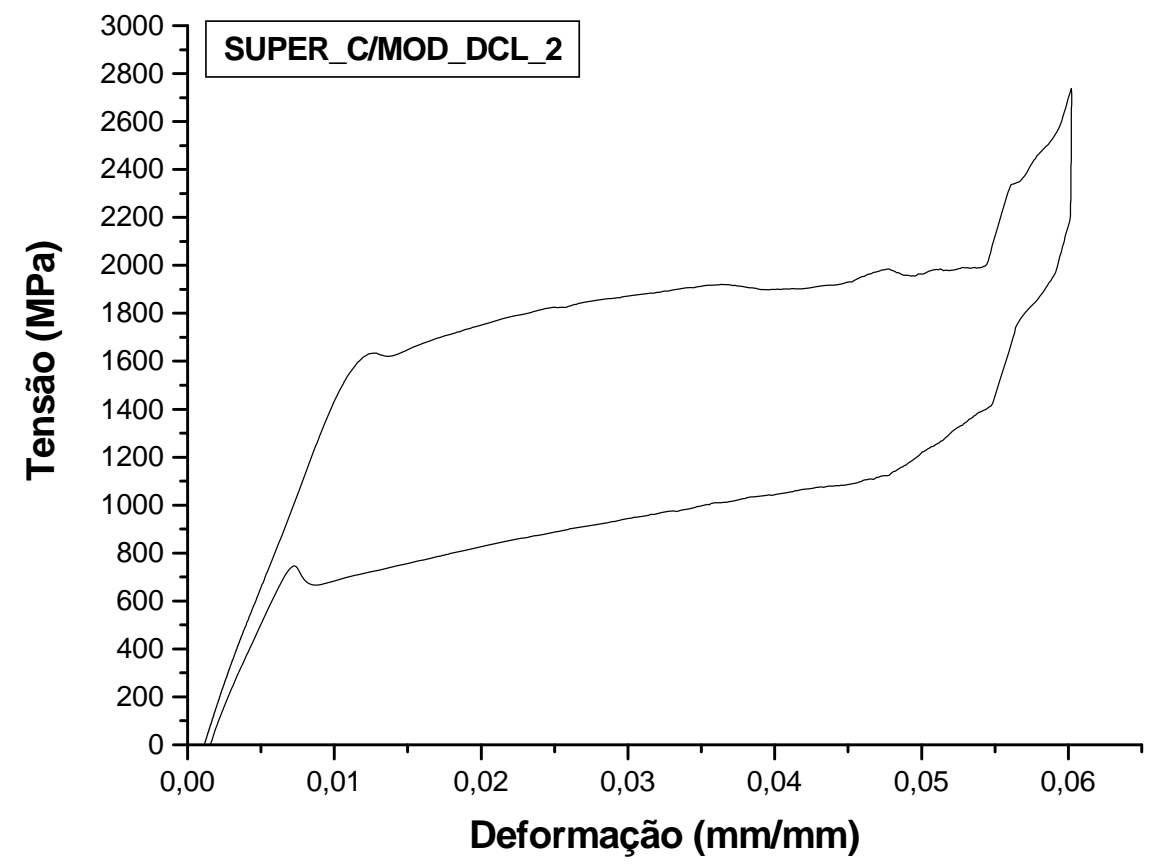




\section{AMOSTRA 3}

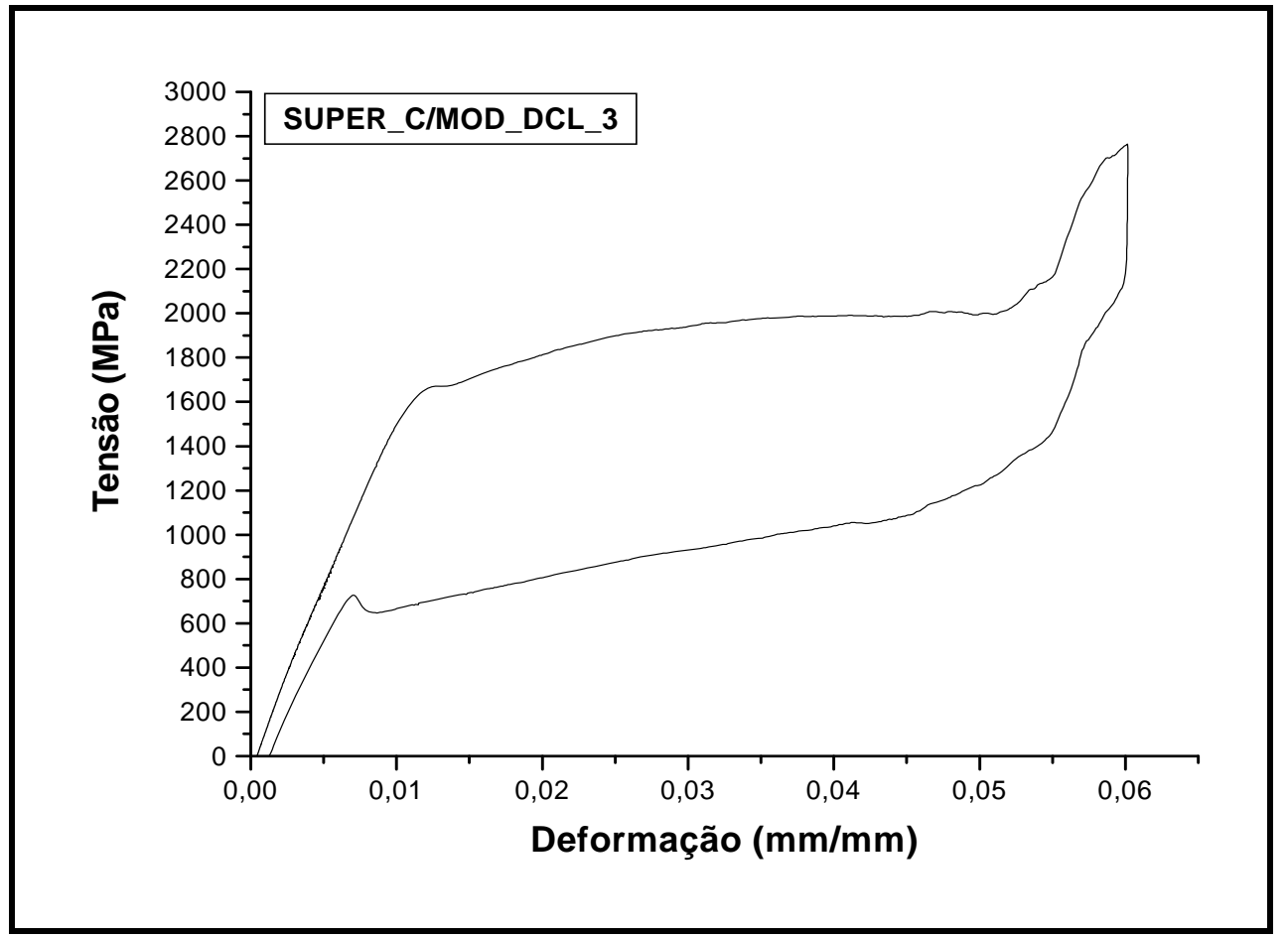

\section{AMOSTRA 4}

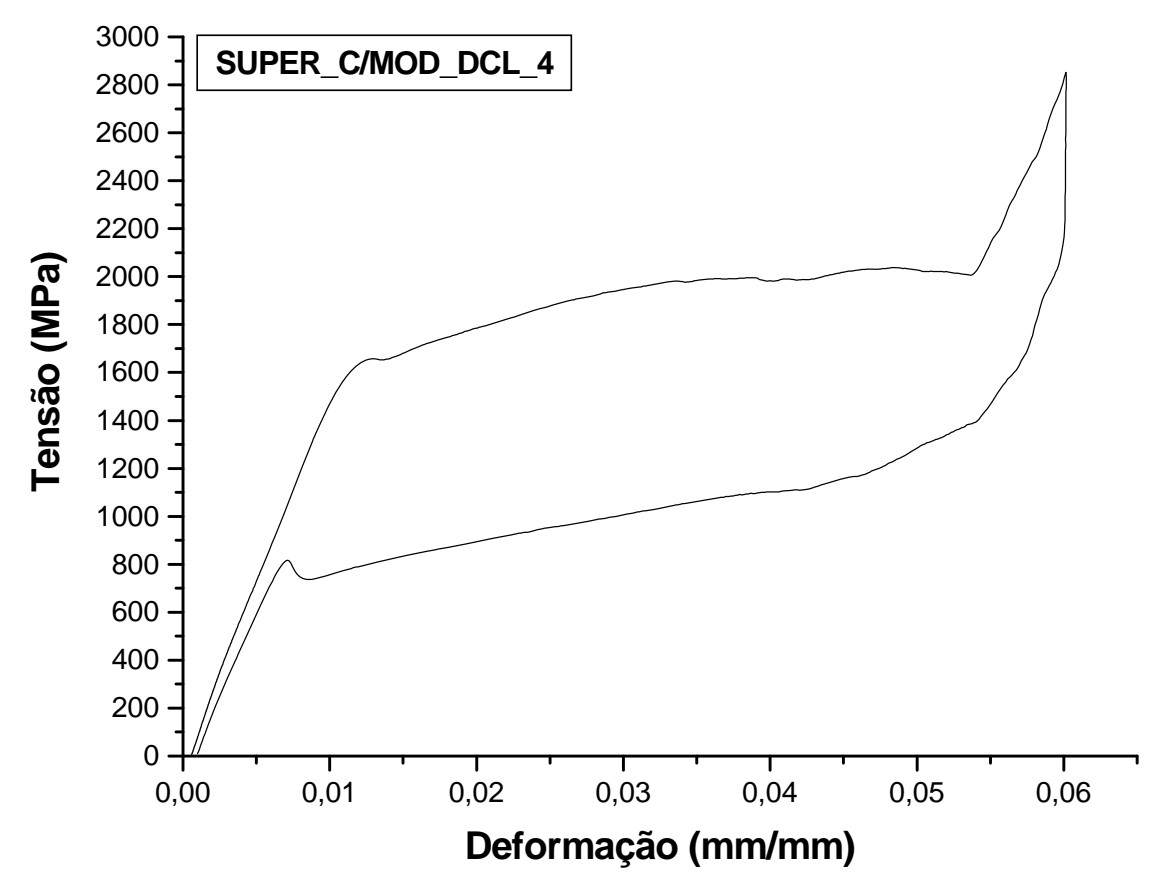




\section{AMOSTRA 5}

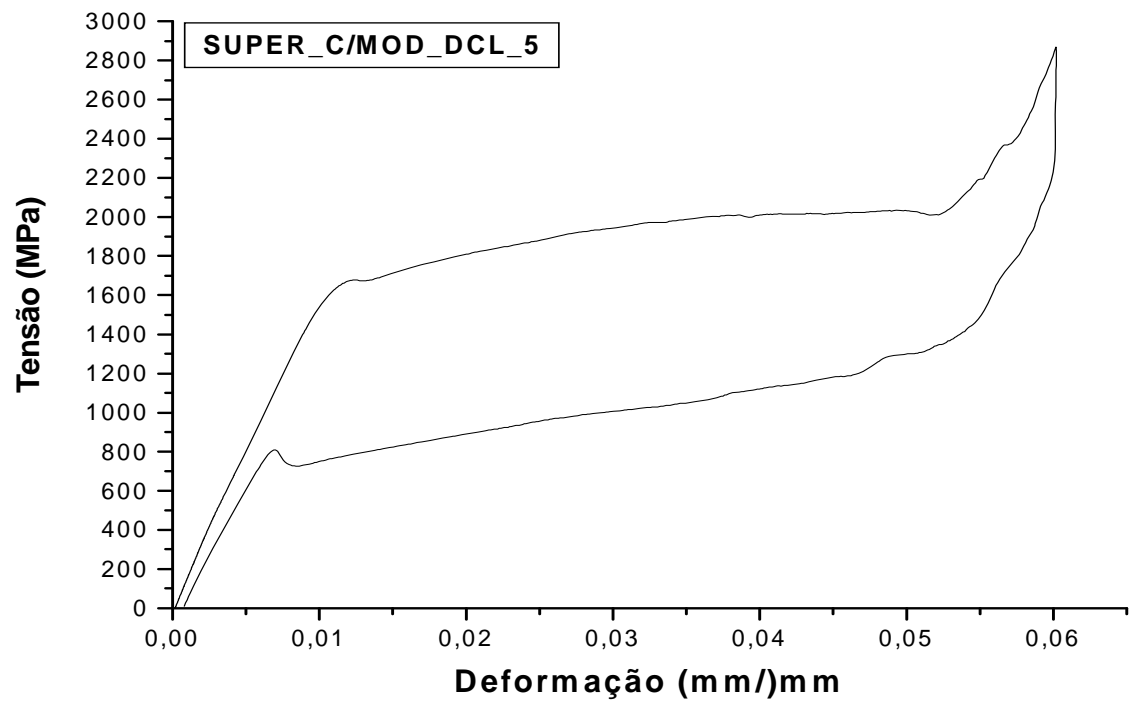

\section{AMOSTRA 6}

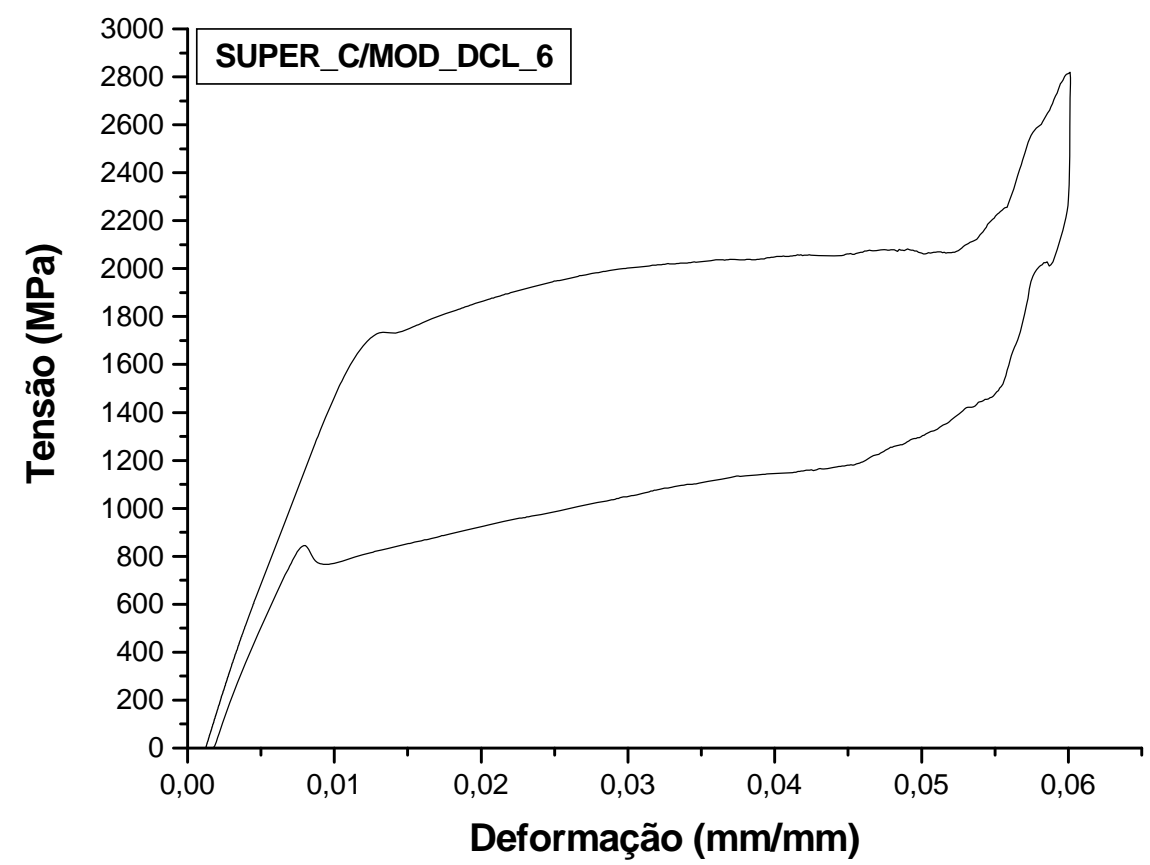




\section{AMOSTRA 7}

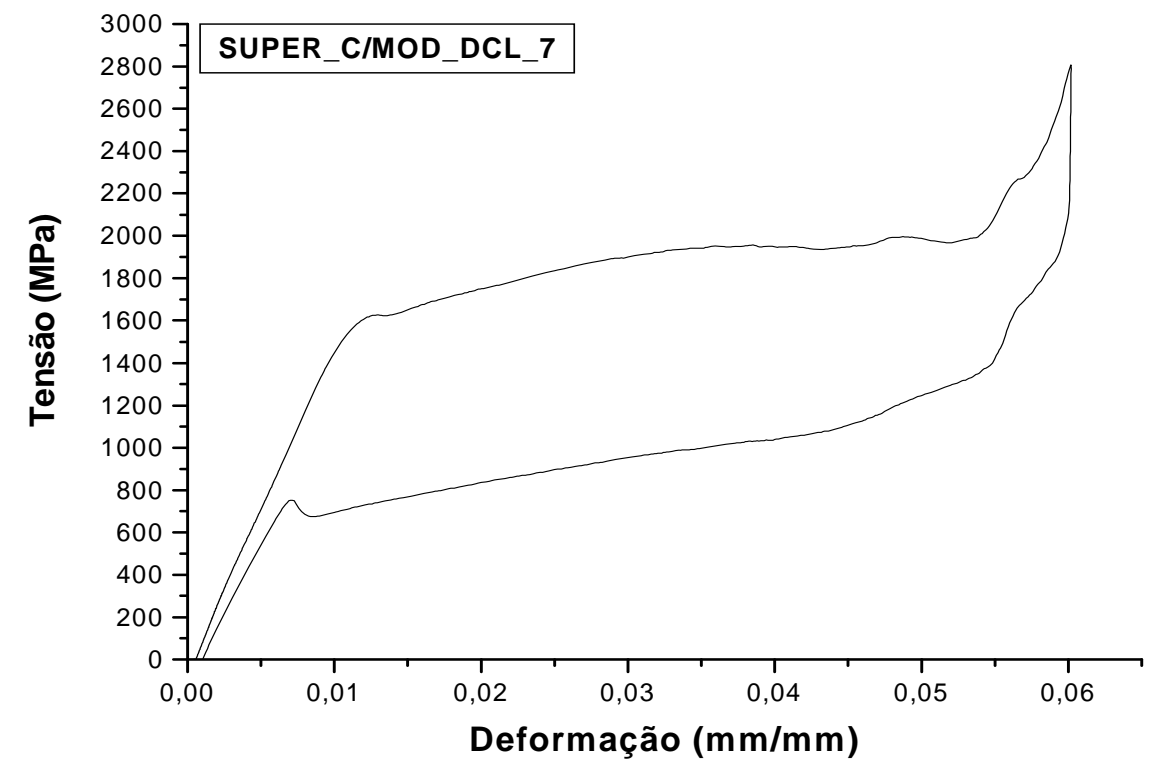

\section{AMOSTRA 8}

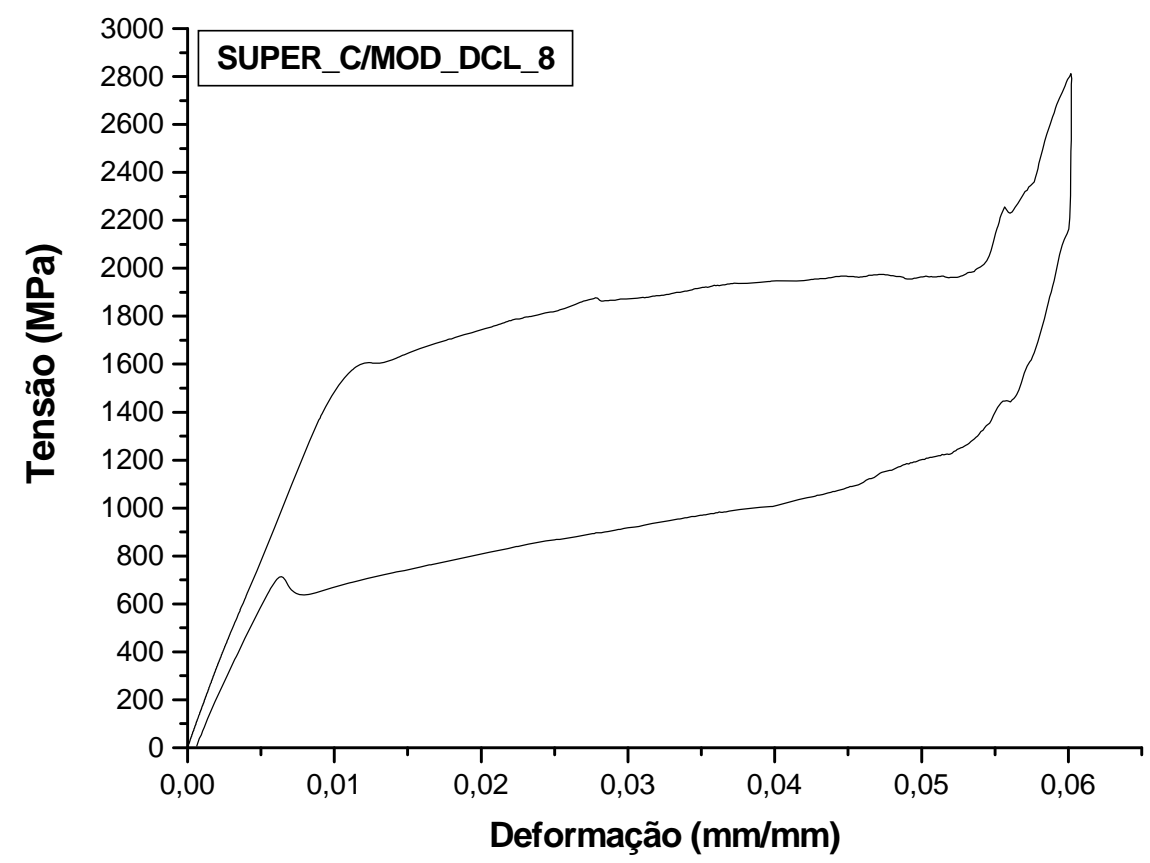




\section{AMOSTRA 9}

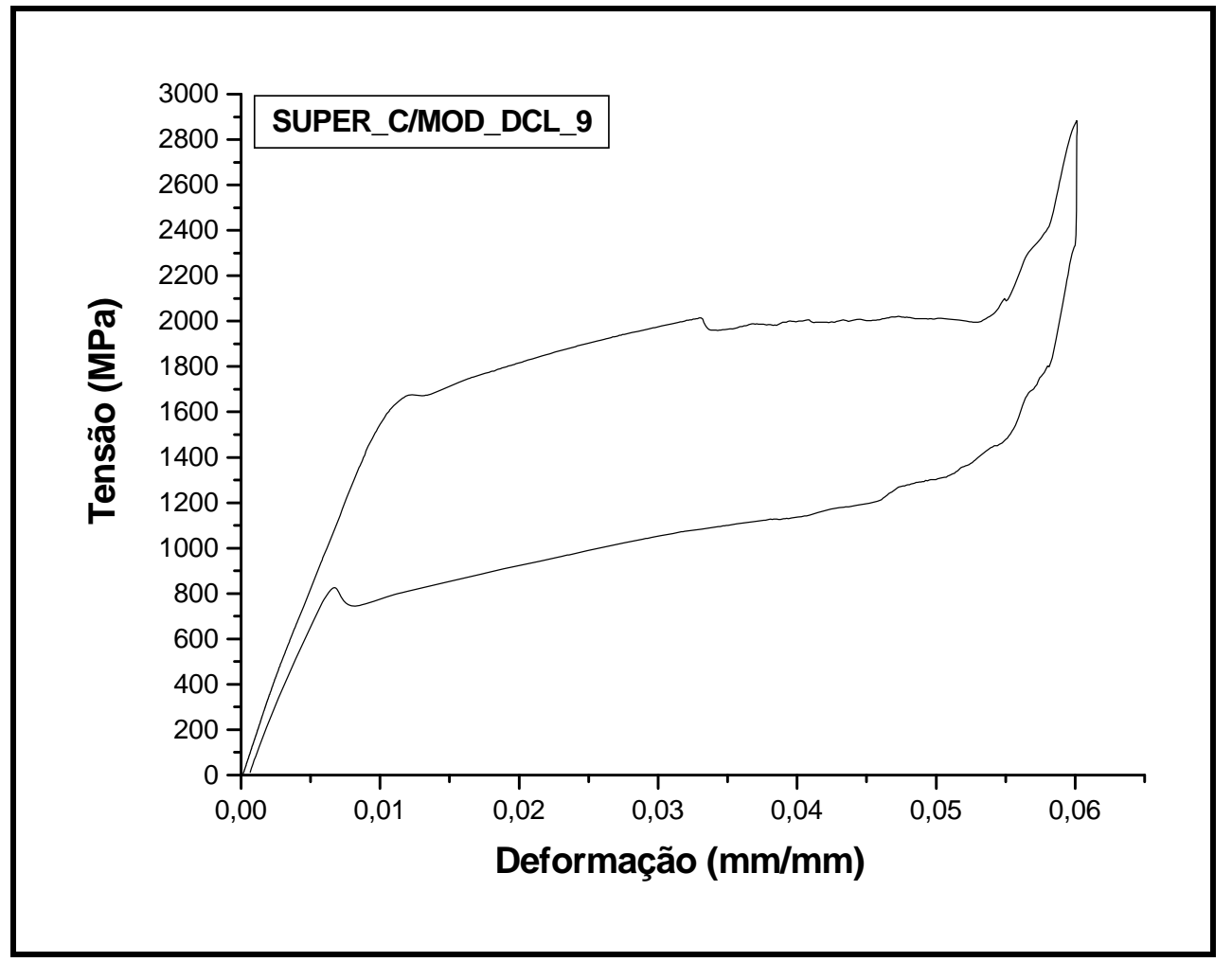

\section{AMOSTRA 10}

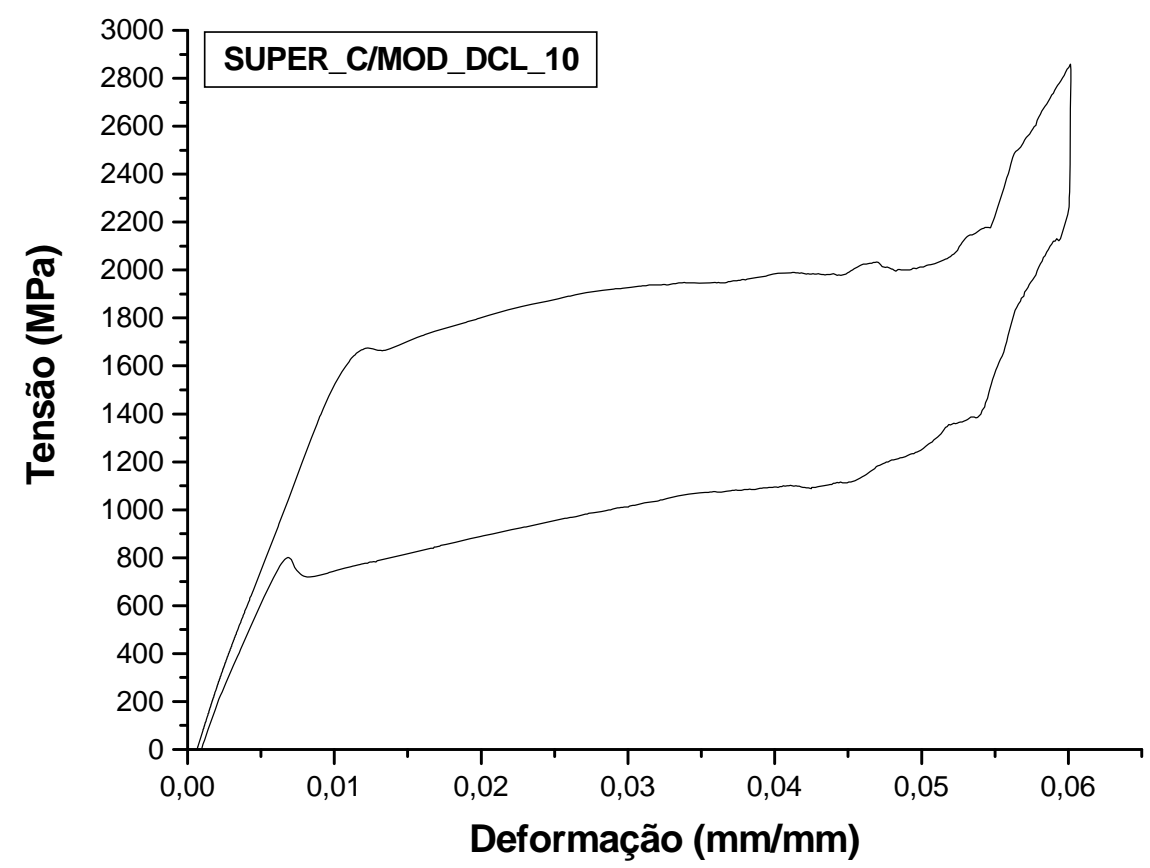


Curvas tensão $X$ deformação das amostras de NiTi termoativado sem modificação.

\section{AMOSTRA 1}

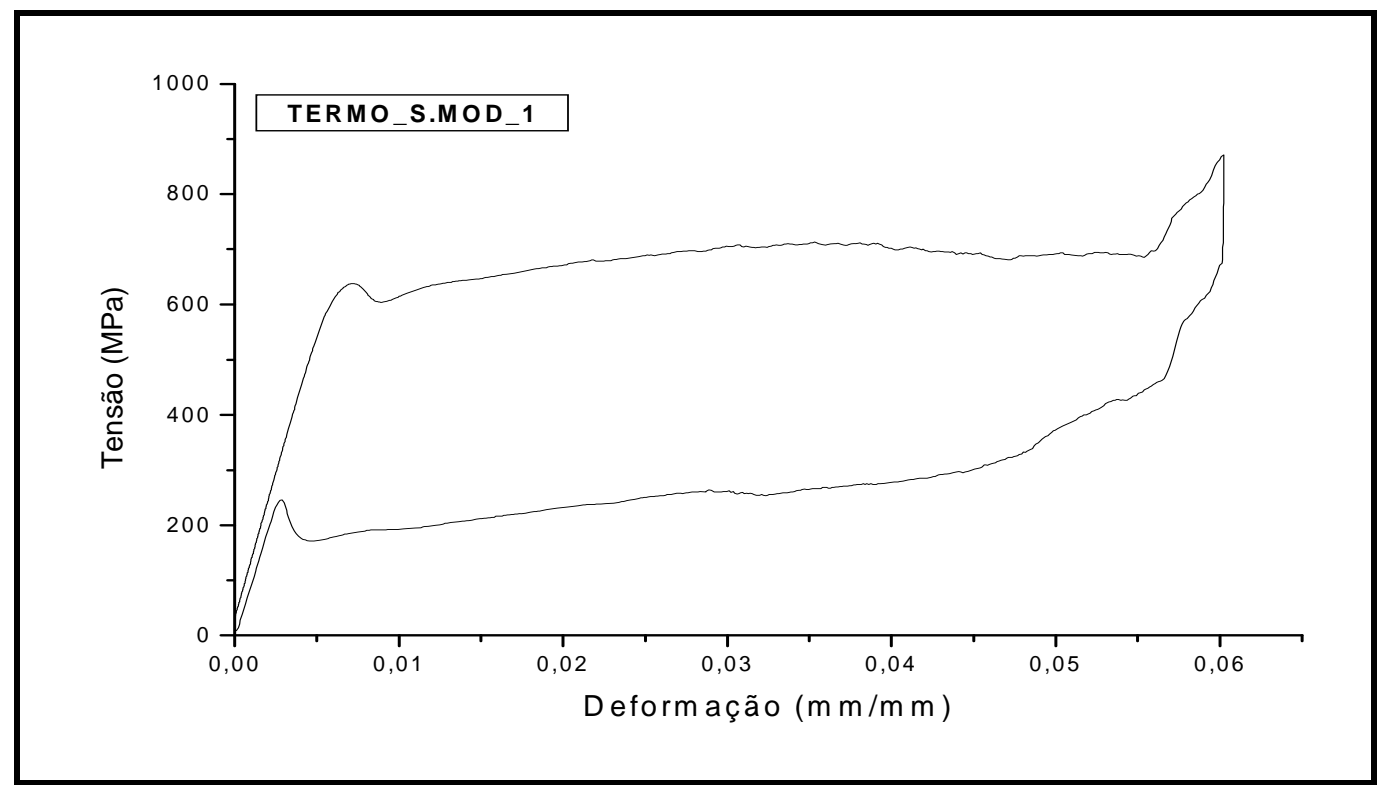

\section{AMOSTRA 2}

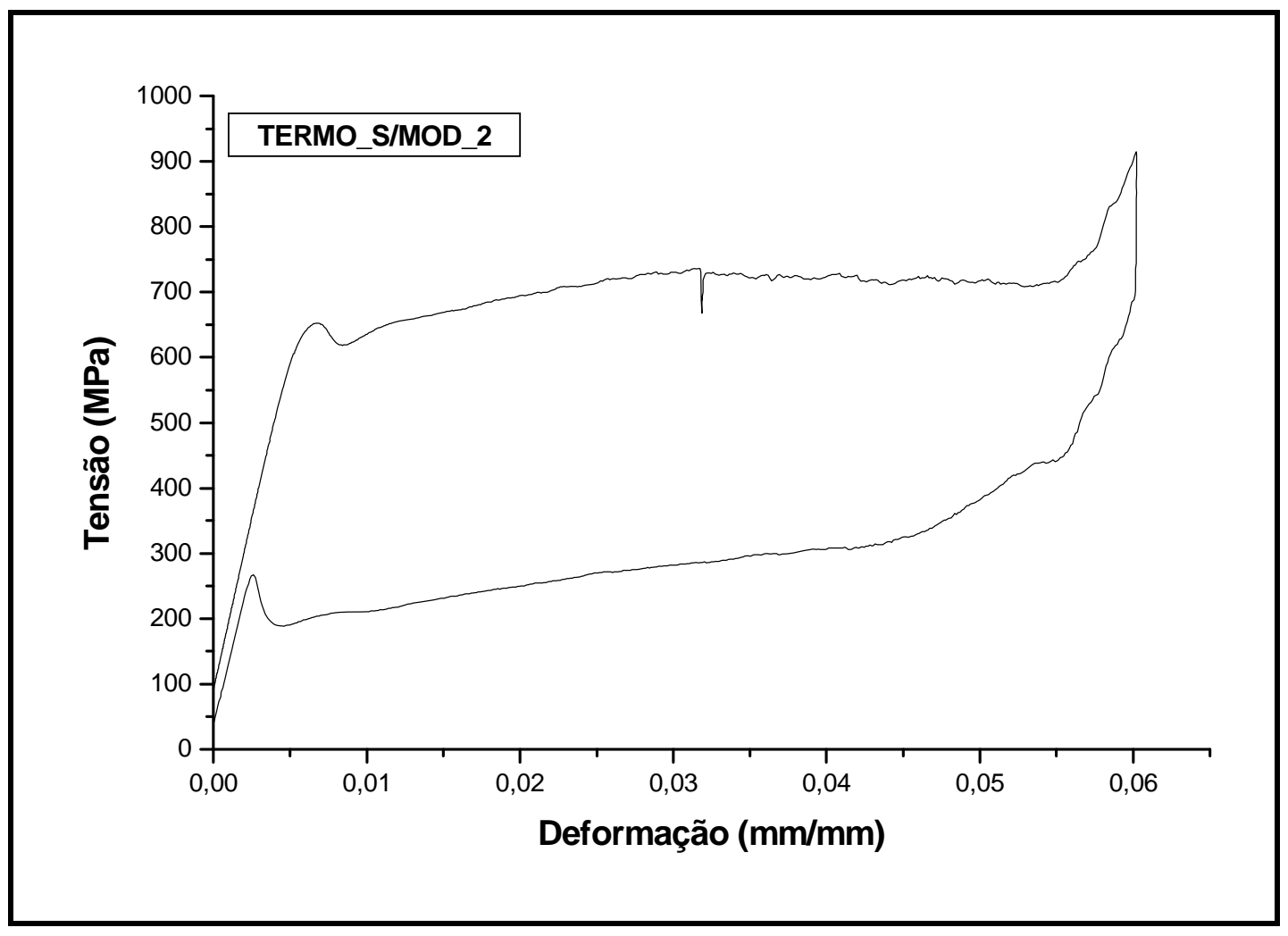




\section{AMOSTRA 3}

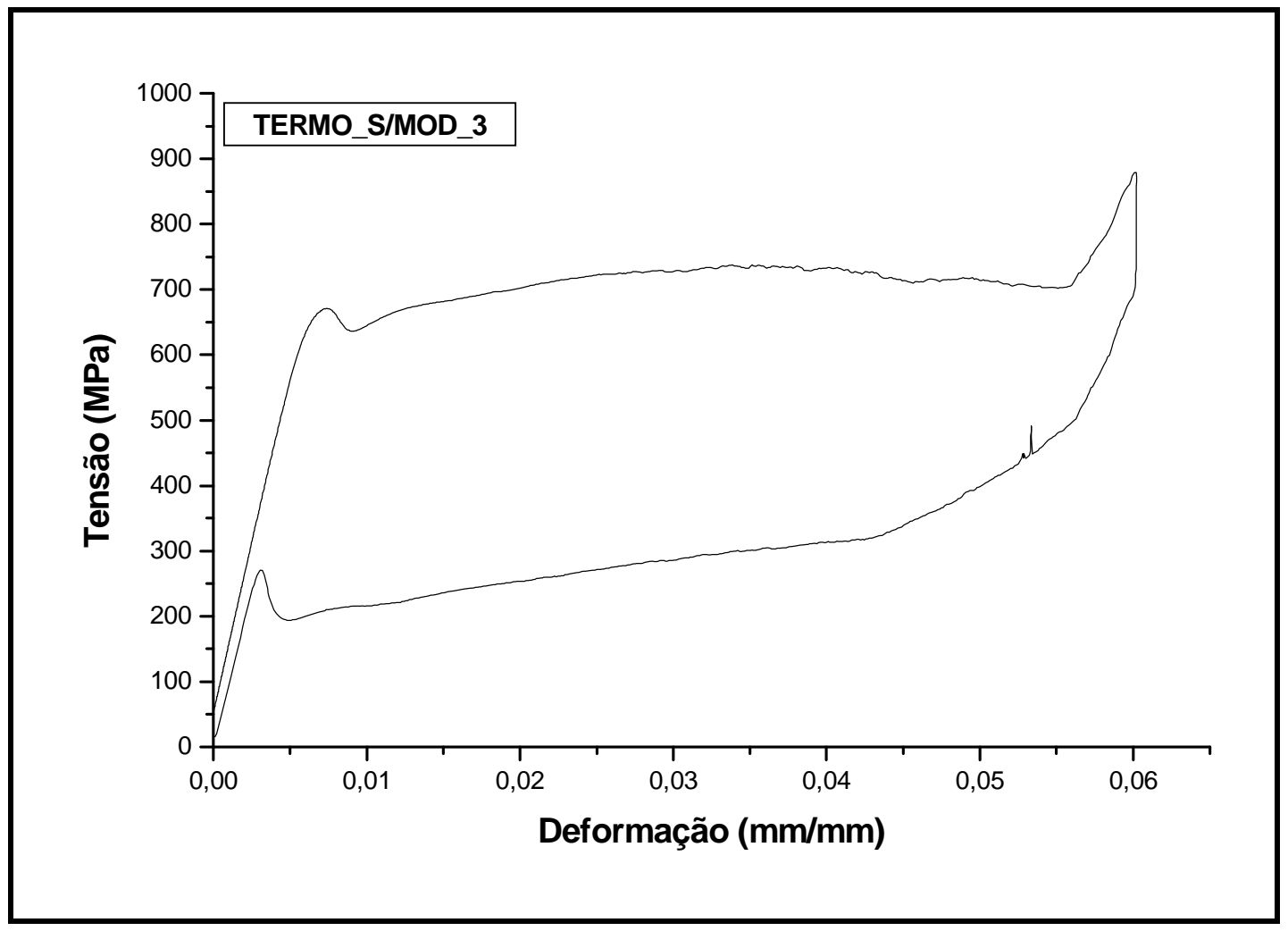

\section{AMOSTRA 4}

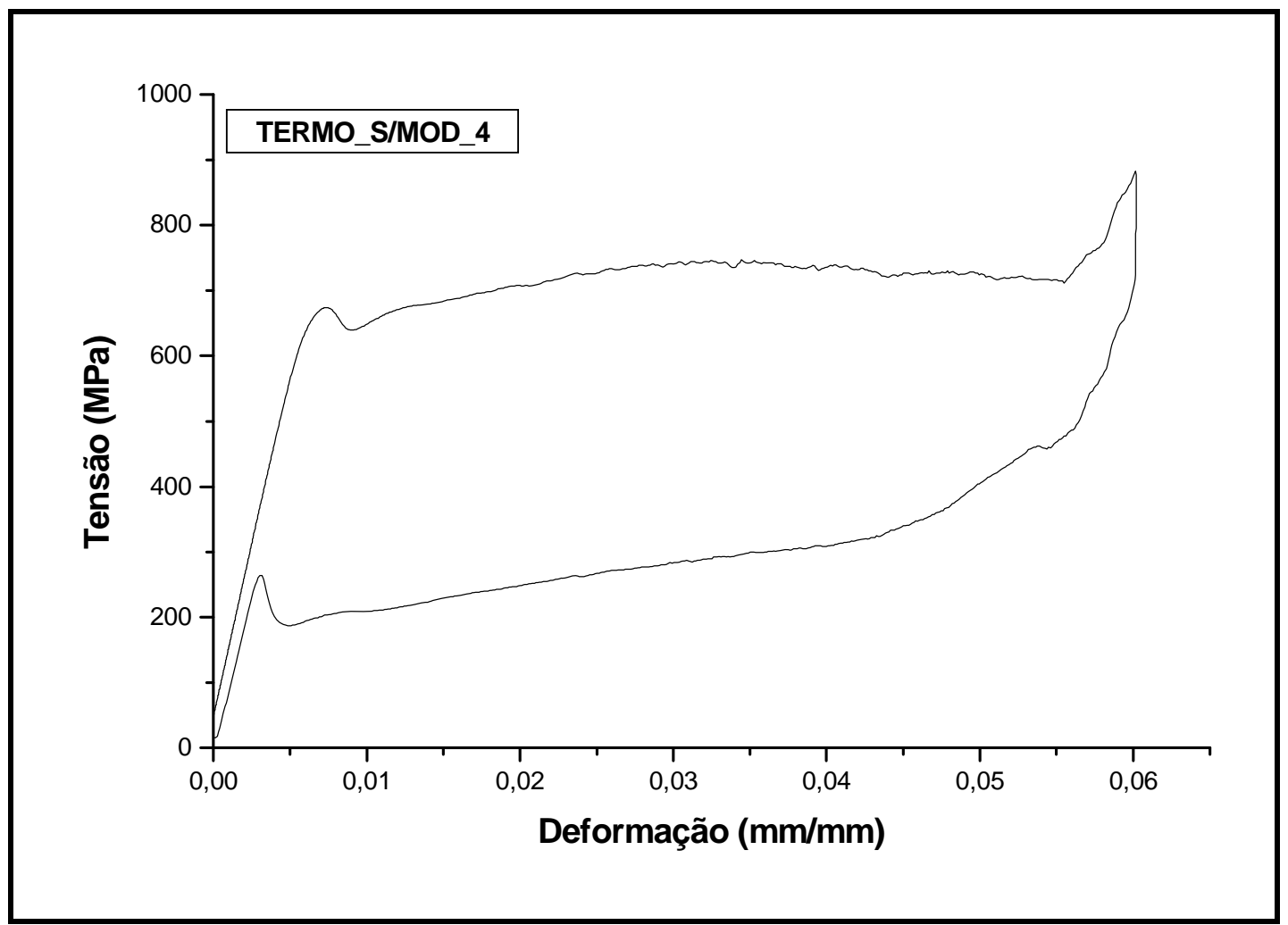




\section{AMOSTRA 5}

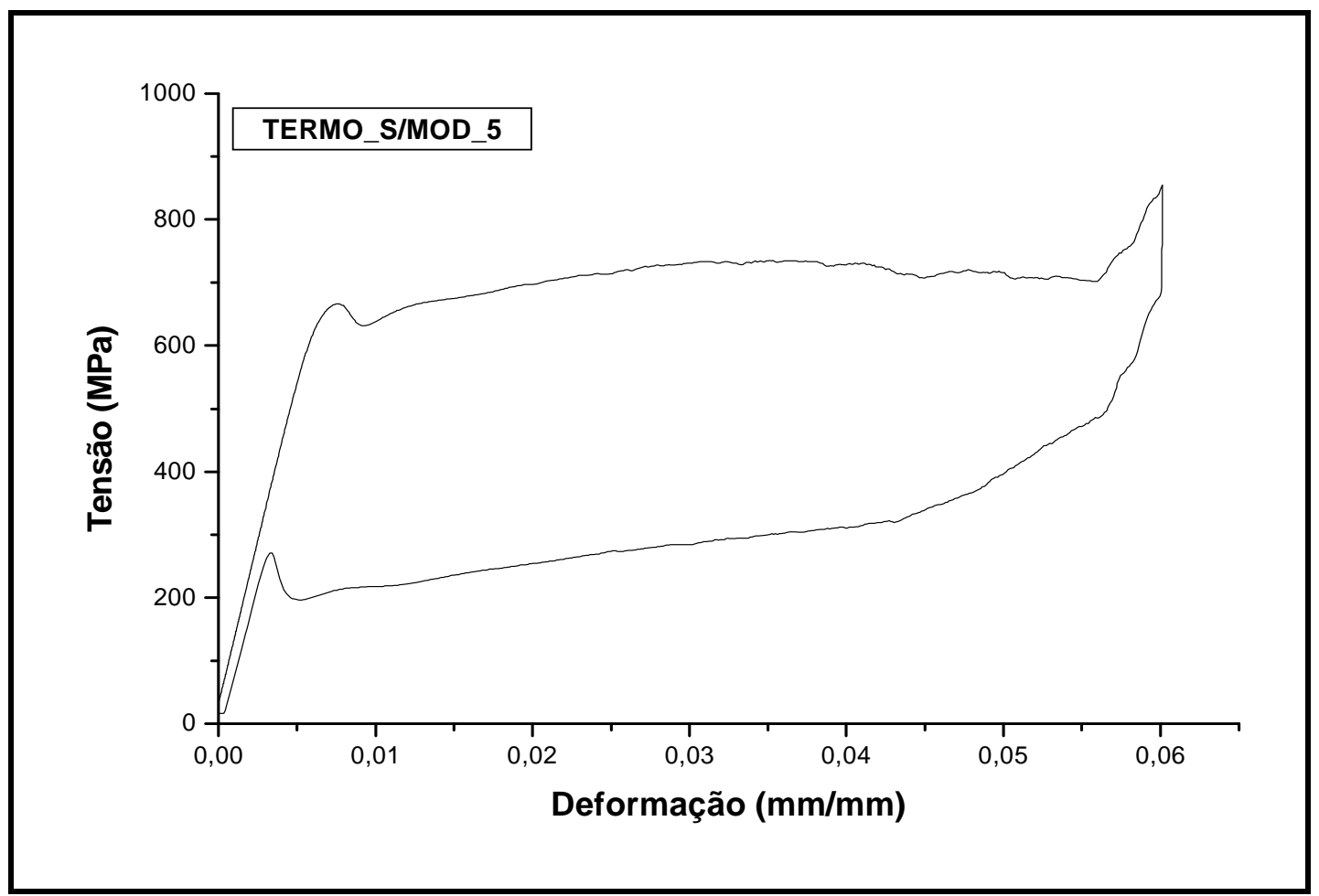

\section{AMOSTRA 6}

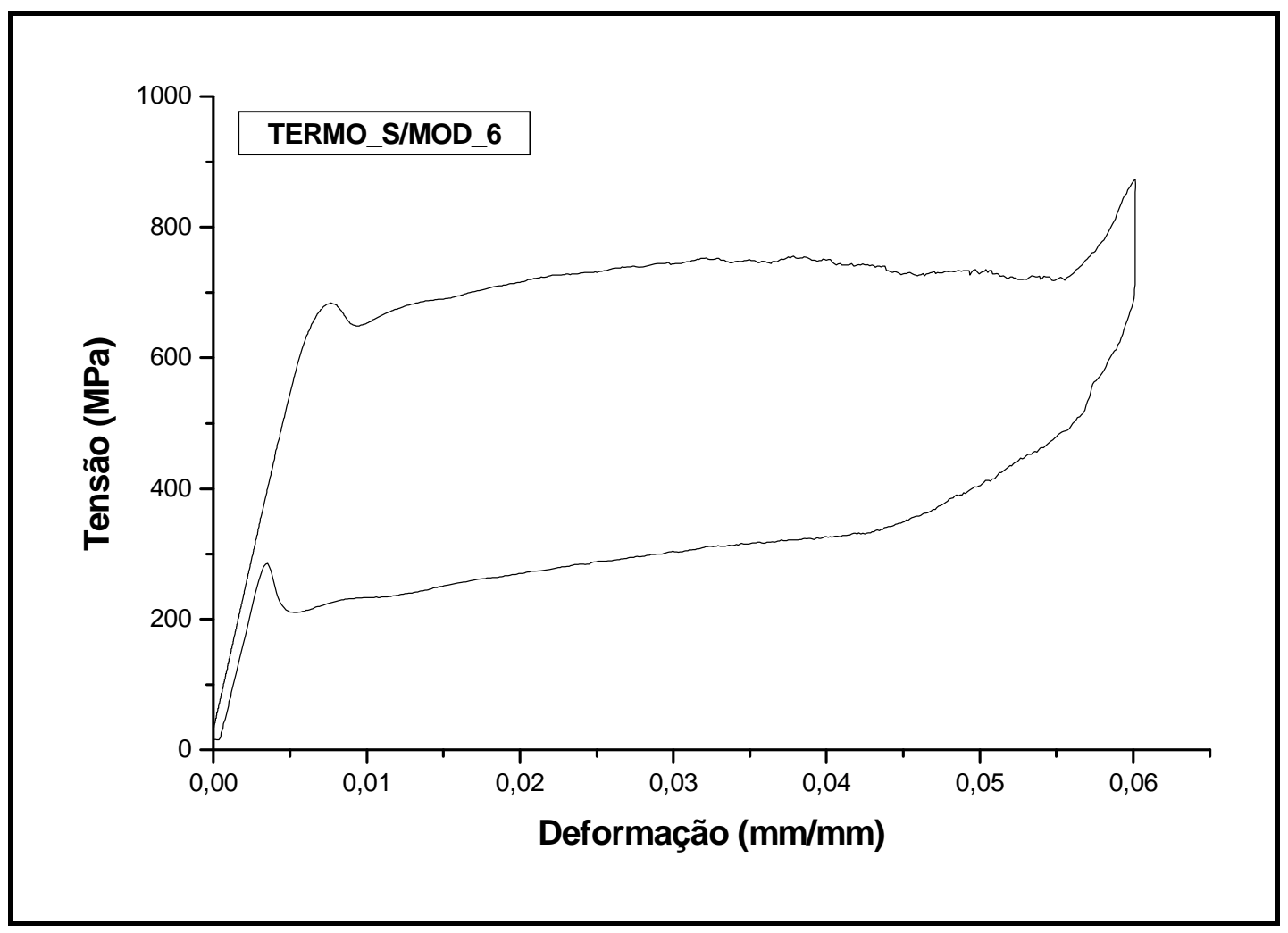




\section{AMOSTRA 7}

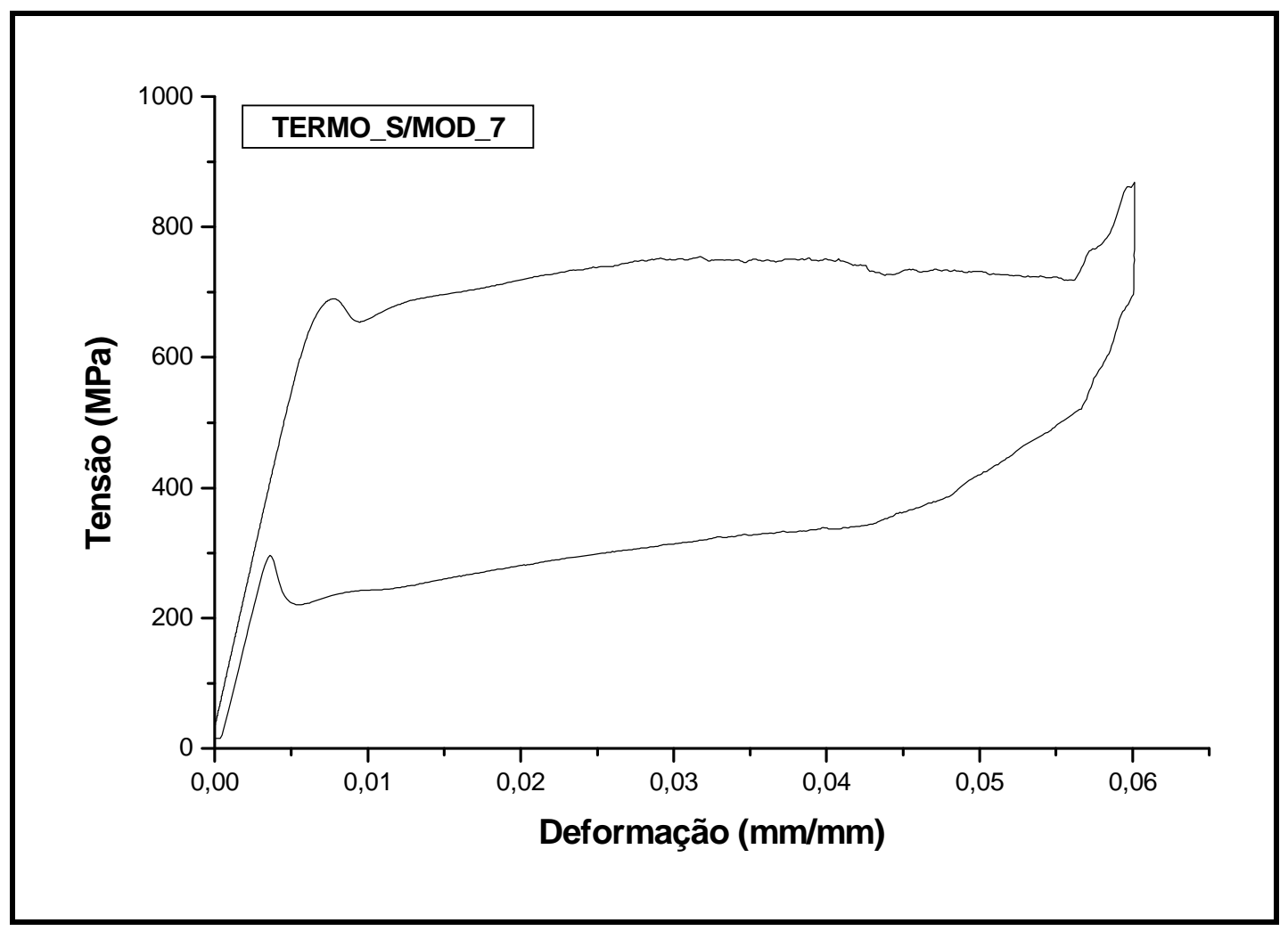

\section{AMOSTRA 8}

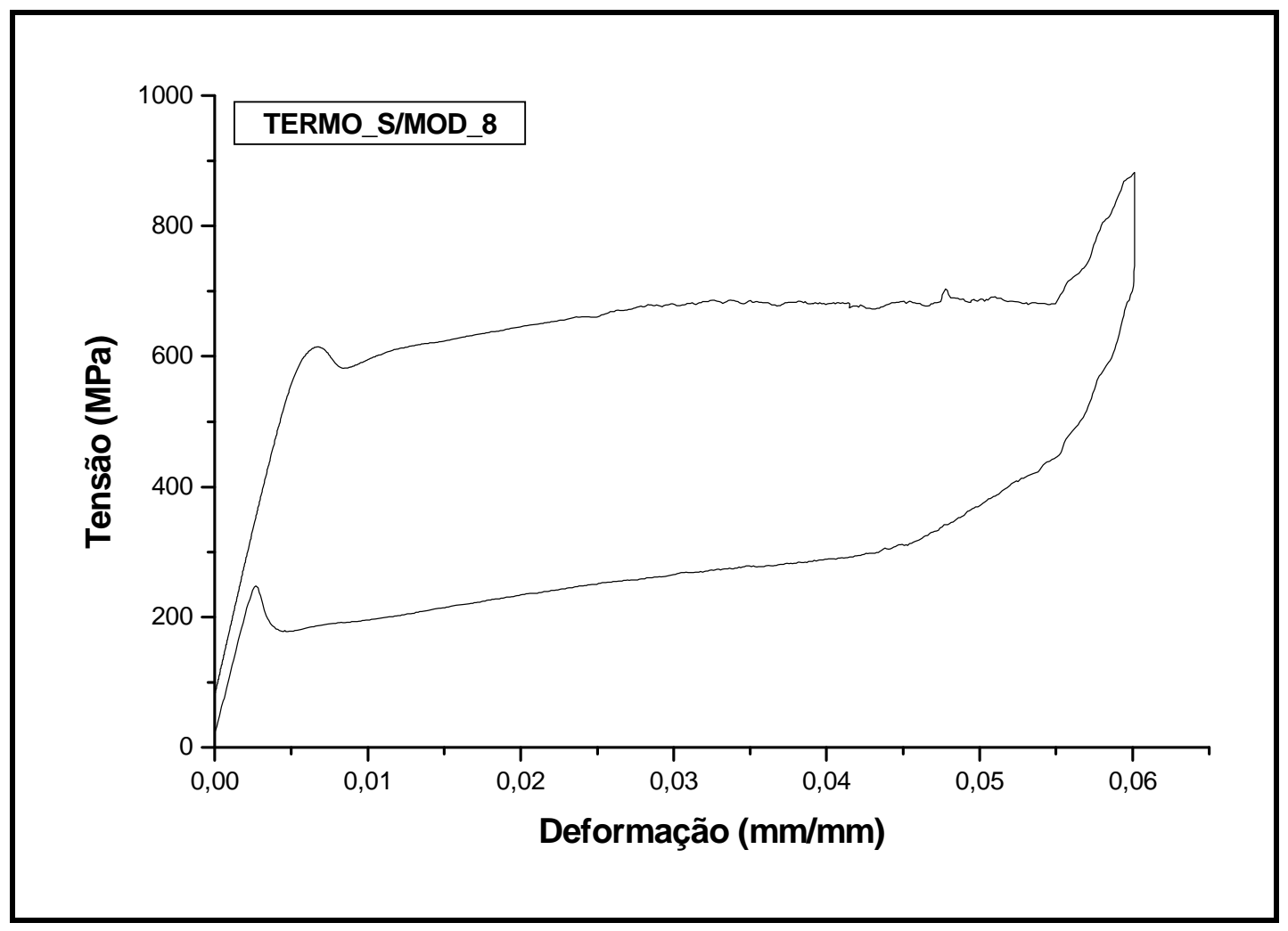




\section{AMOSTRA 9}

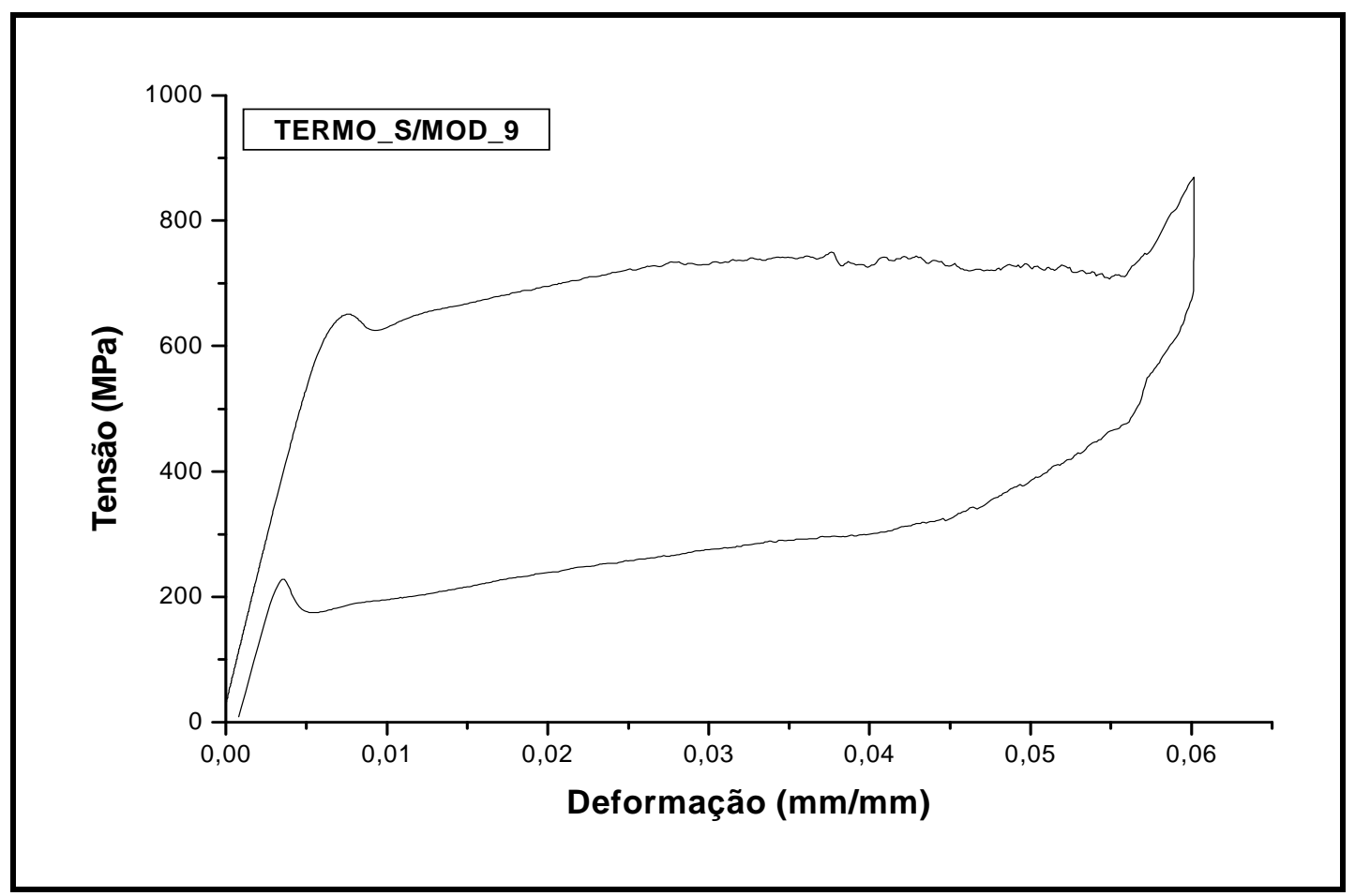

\section{AMOSTRA 10}

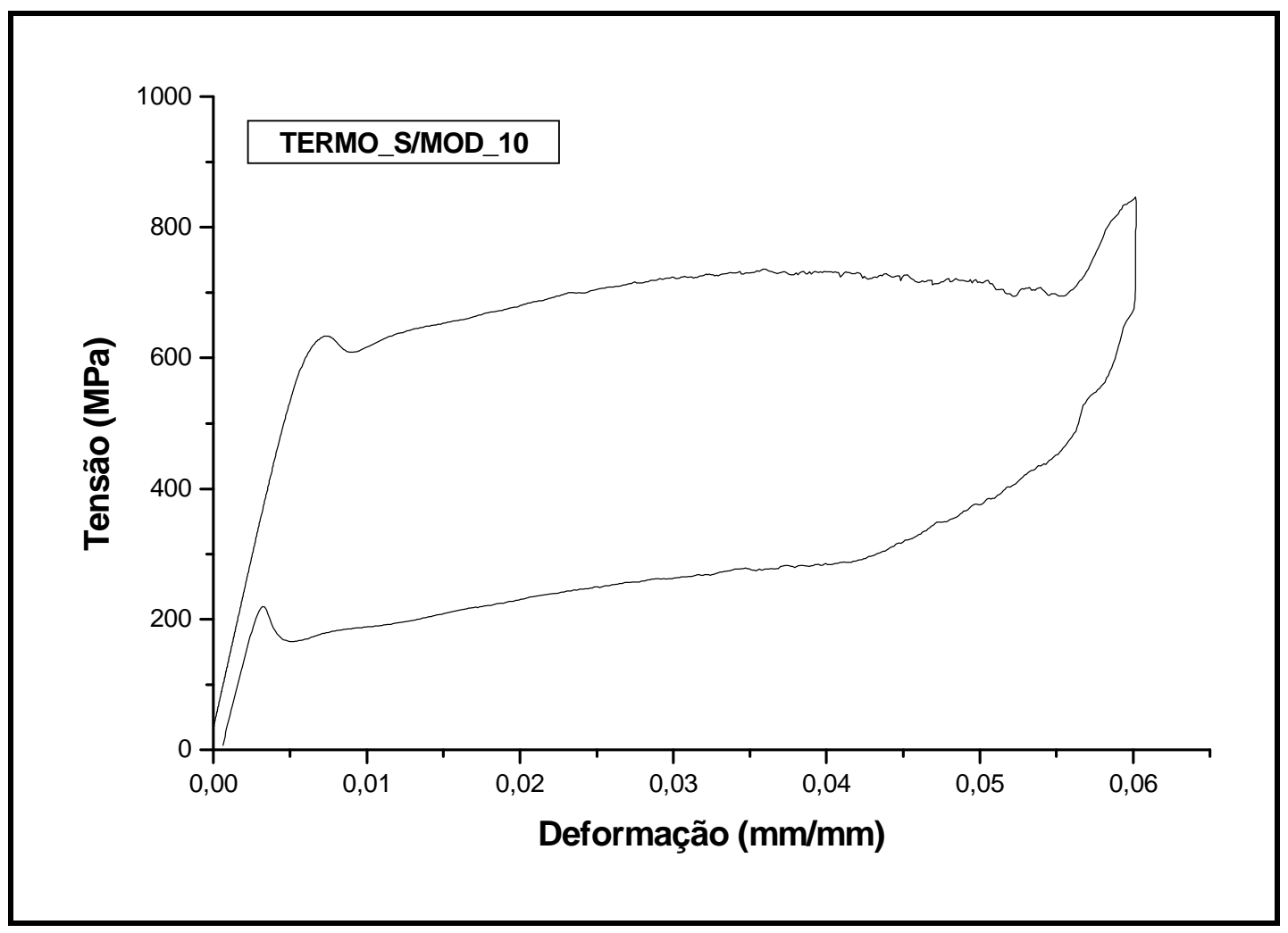


Curvas tensão $X$ deformação das amostras de NiTi termoativado com modificação

\section{AMOSTRA 1}

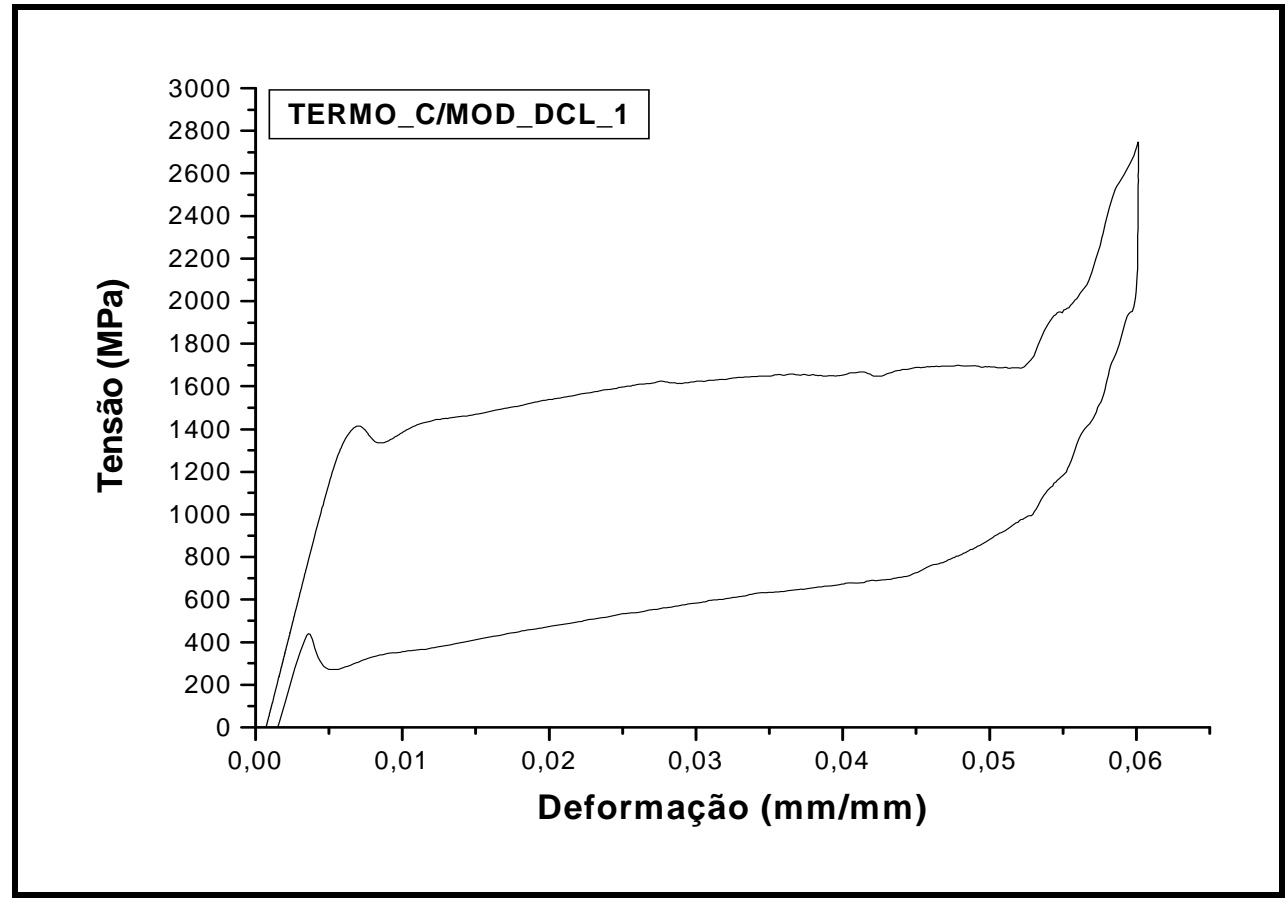

\section{AMOSTRA 2}

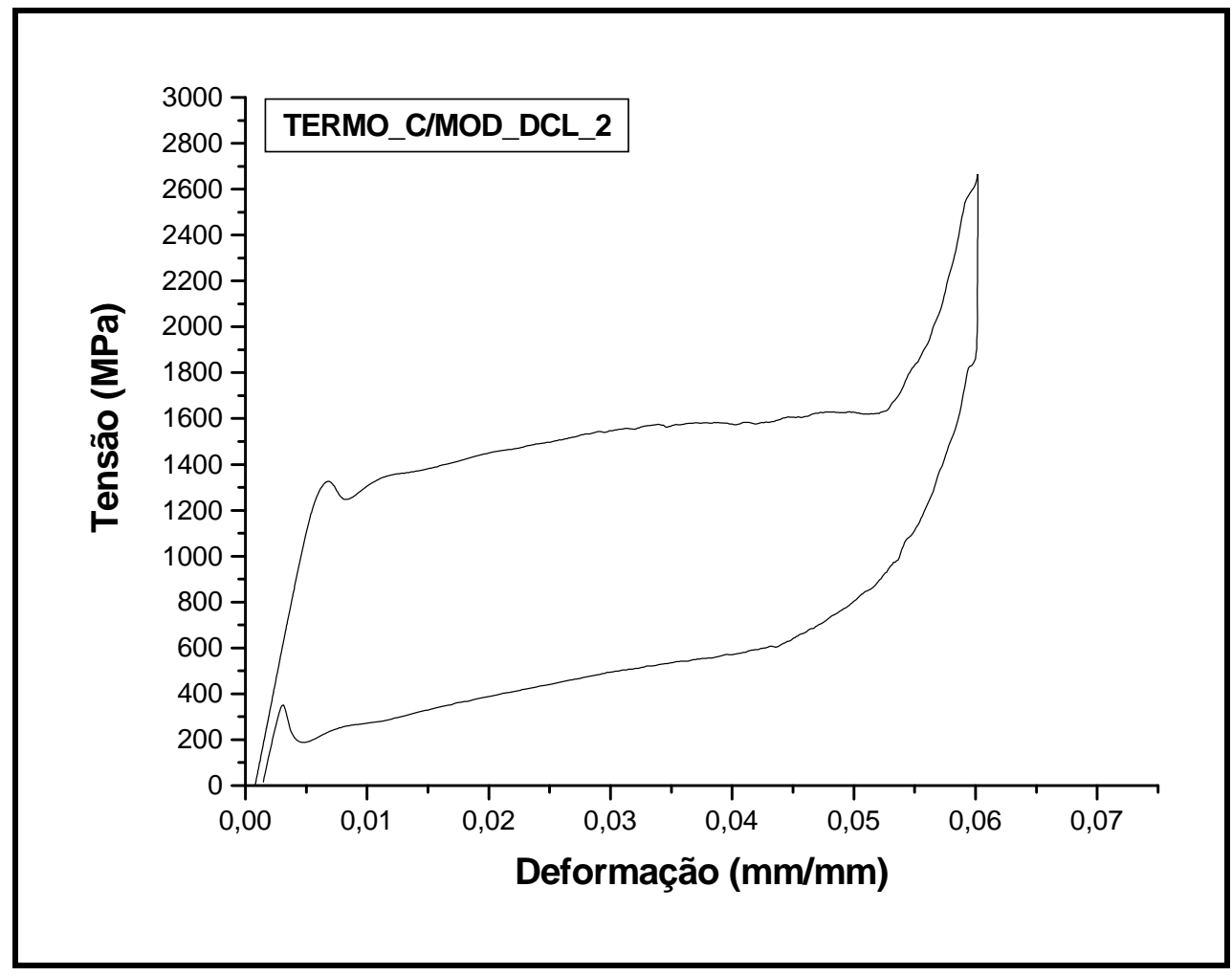




\section{AMOSTRA 3}

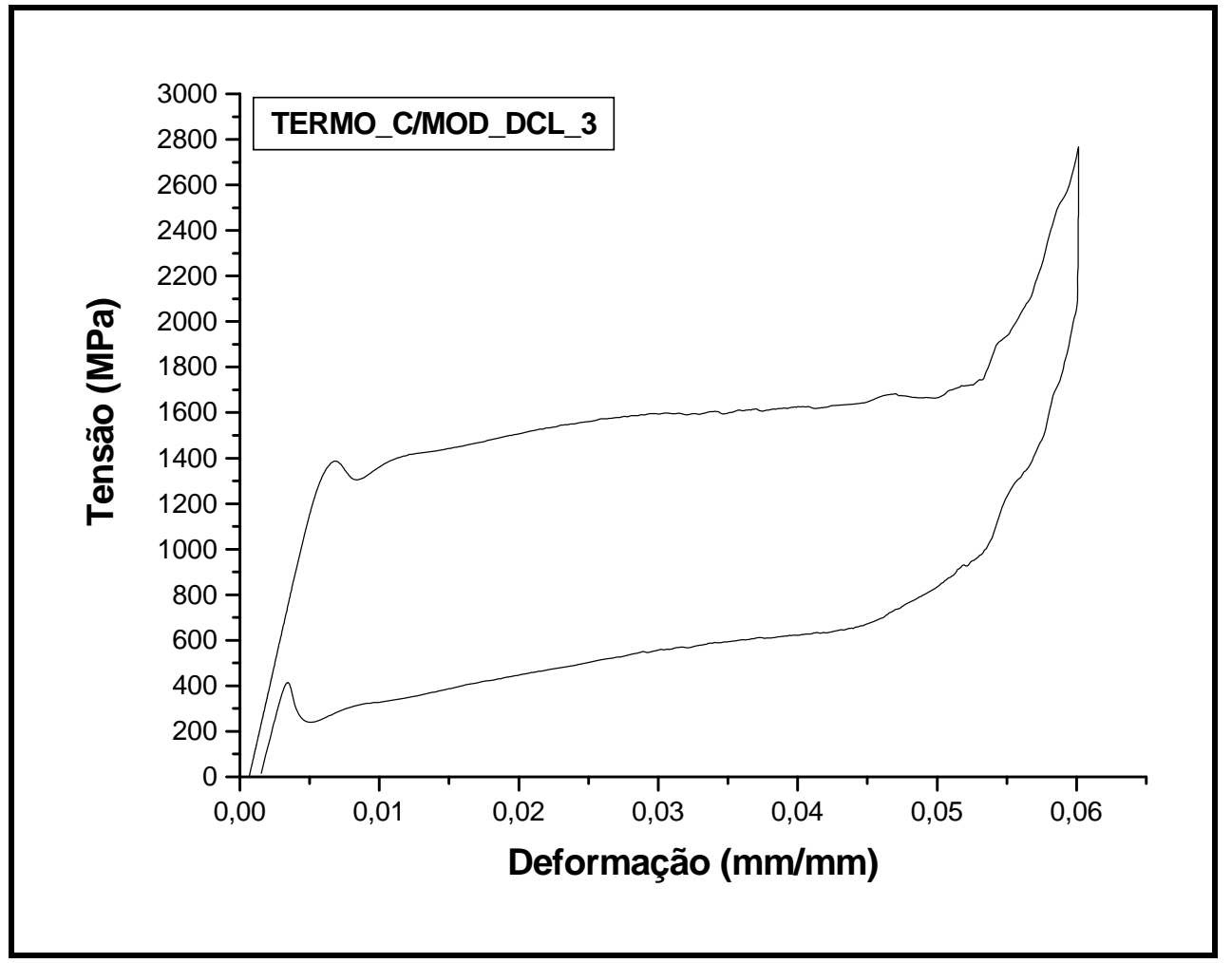

\section{AMOSTRA 4}

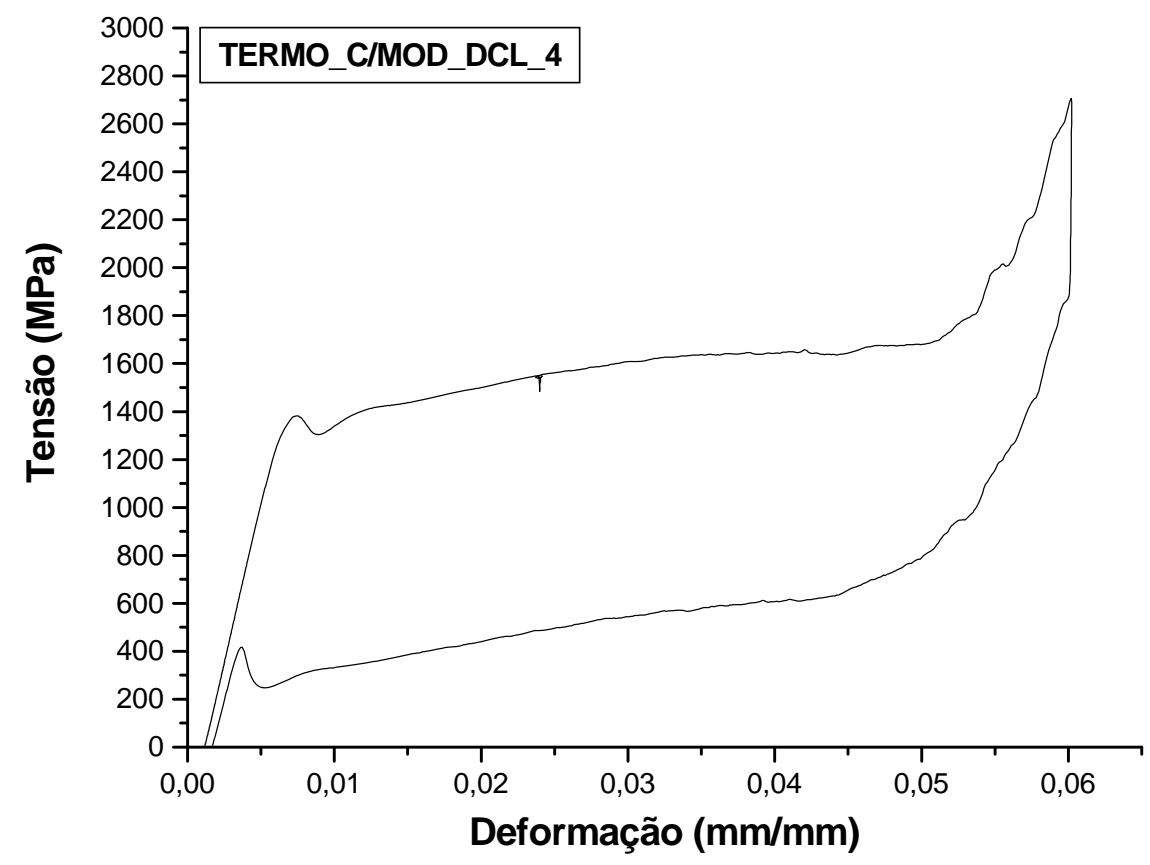




\section{AMOSTRA 5}

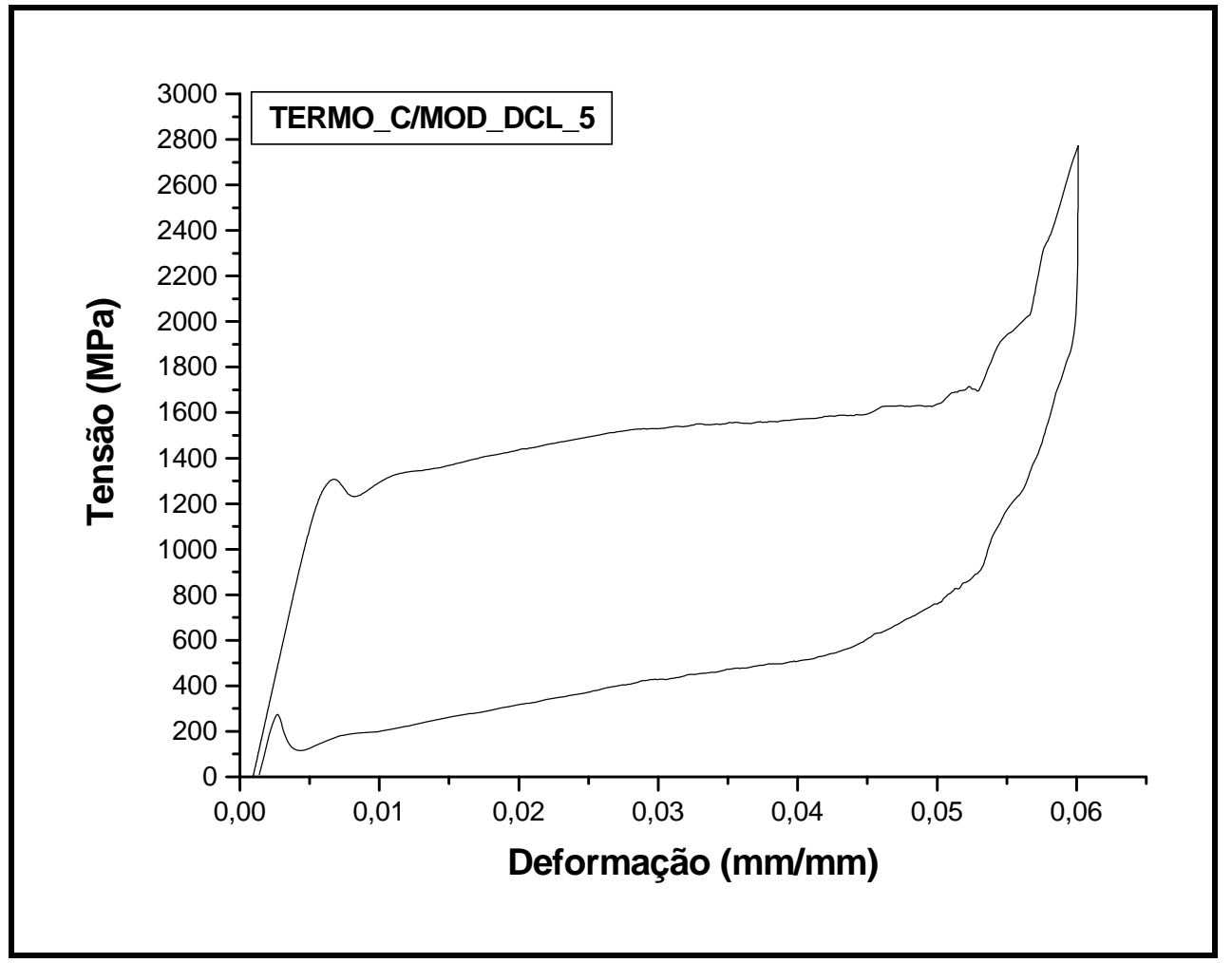

\section{AMOSTRA 6}

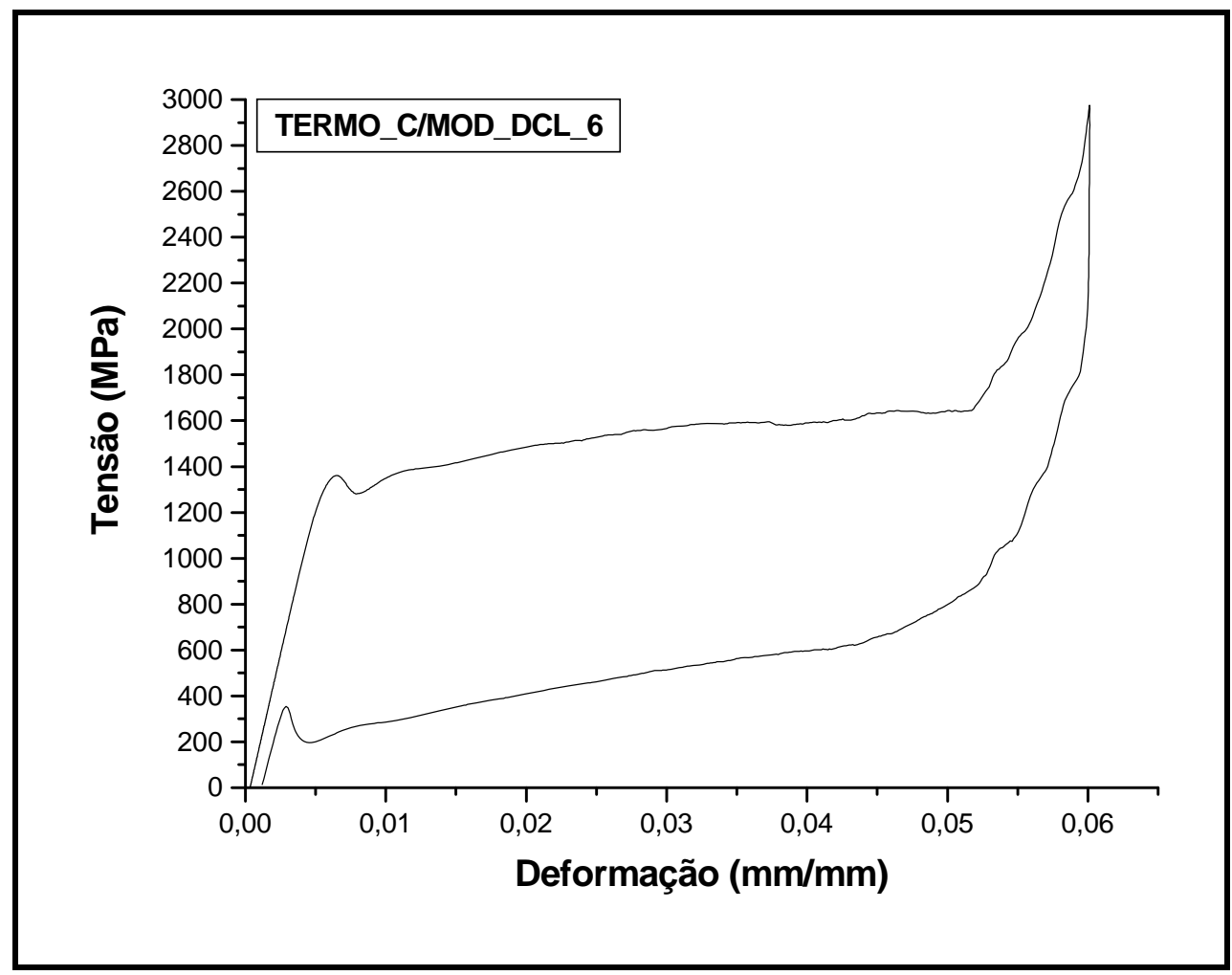




\section{AMOSTRA 7}

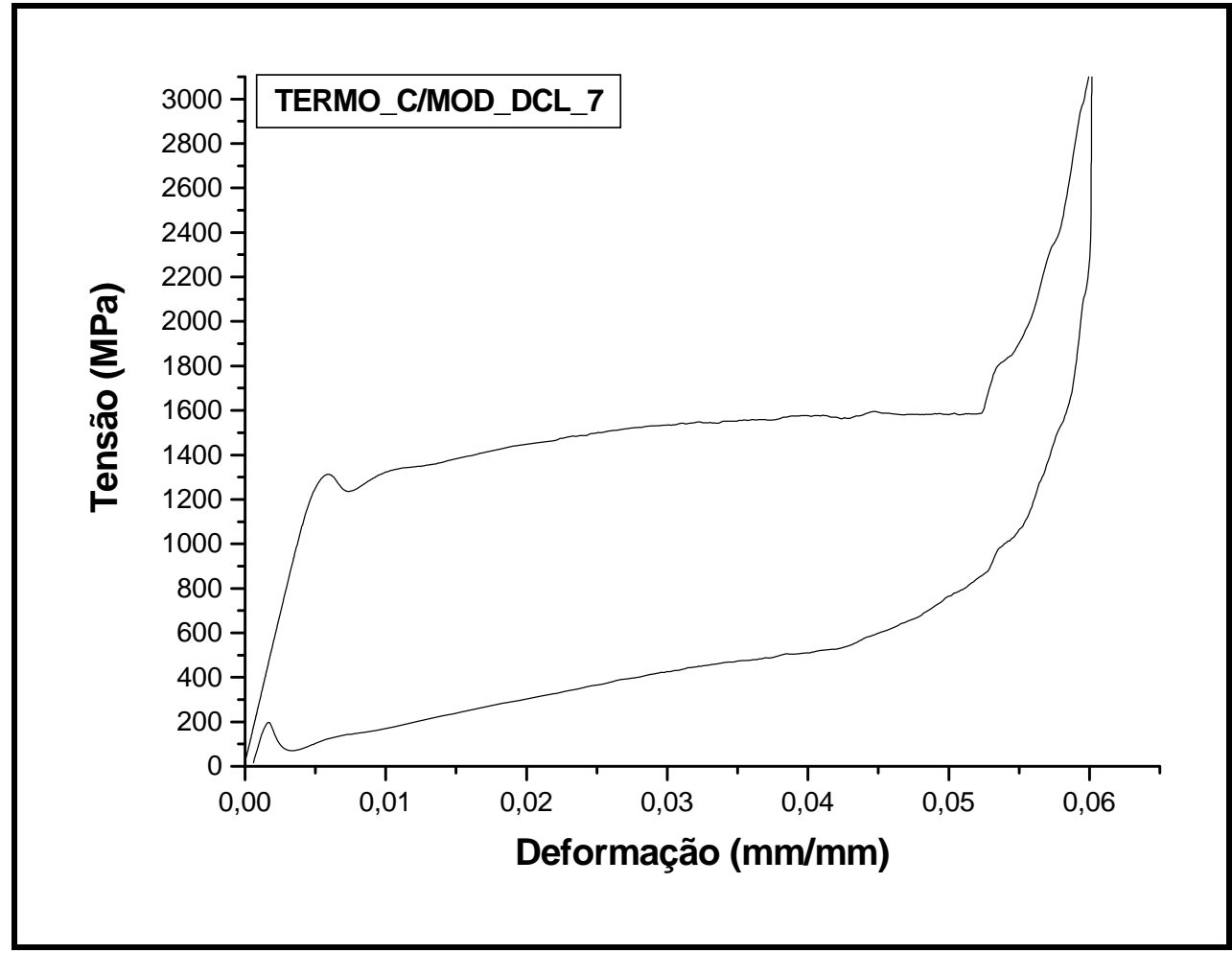

\section{AMOSTRA 8}

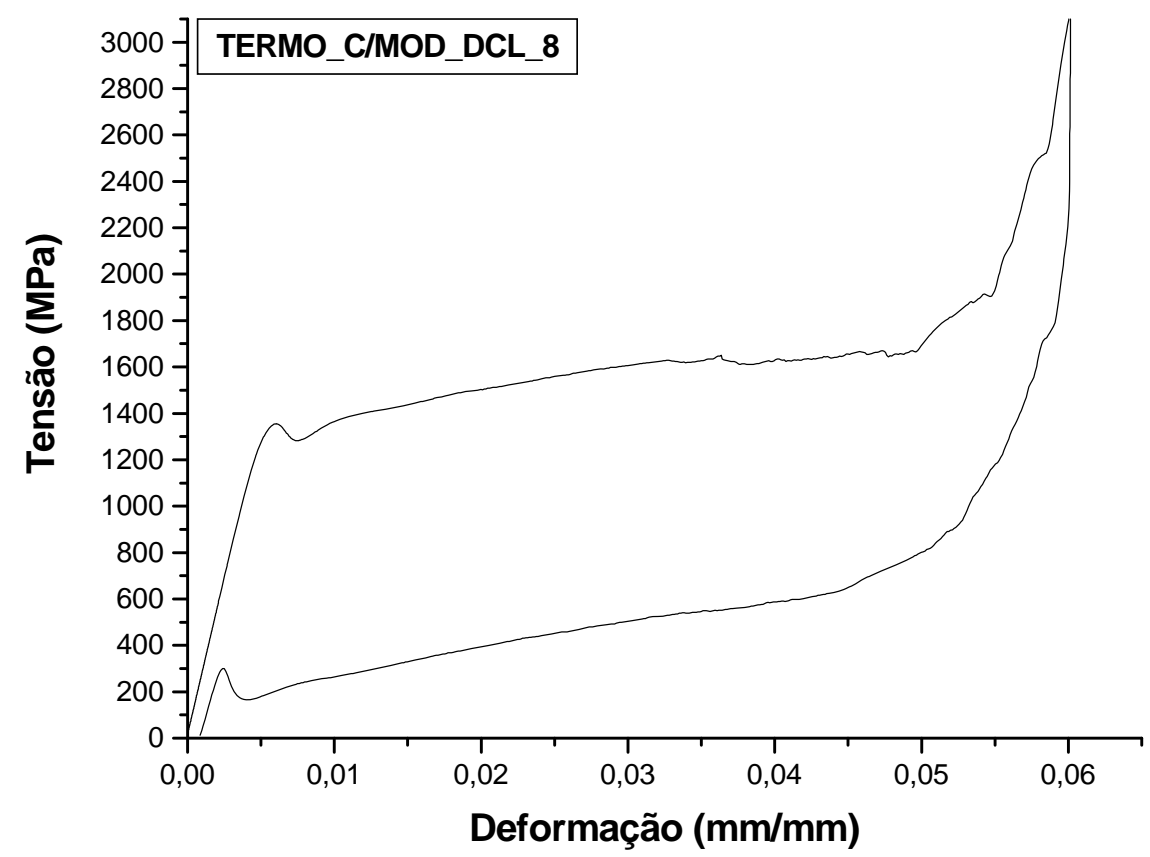




\section{AMOSTRA 9}

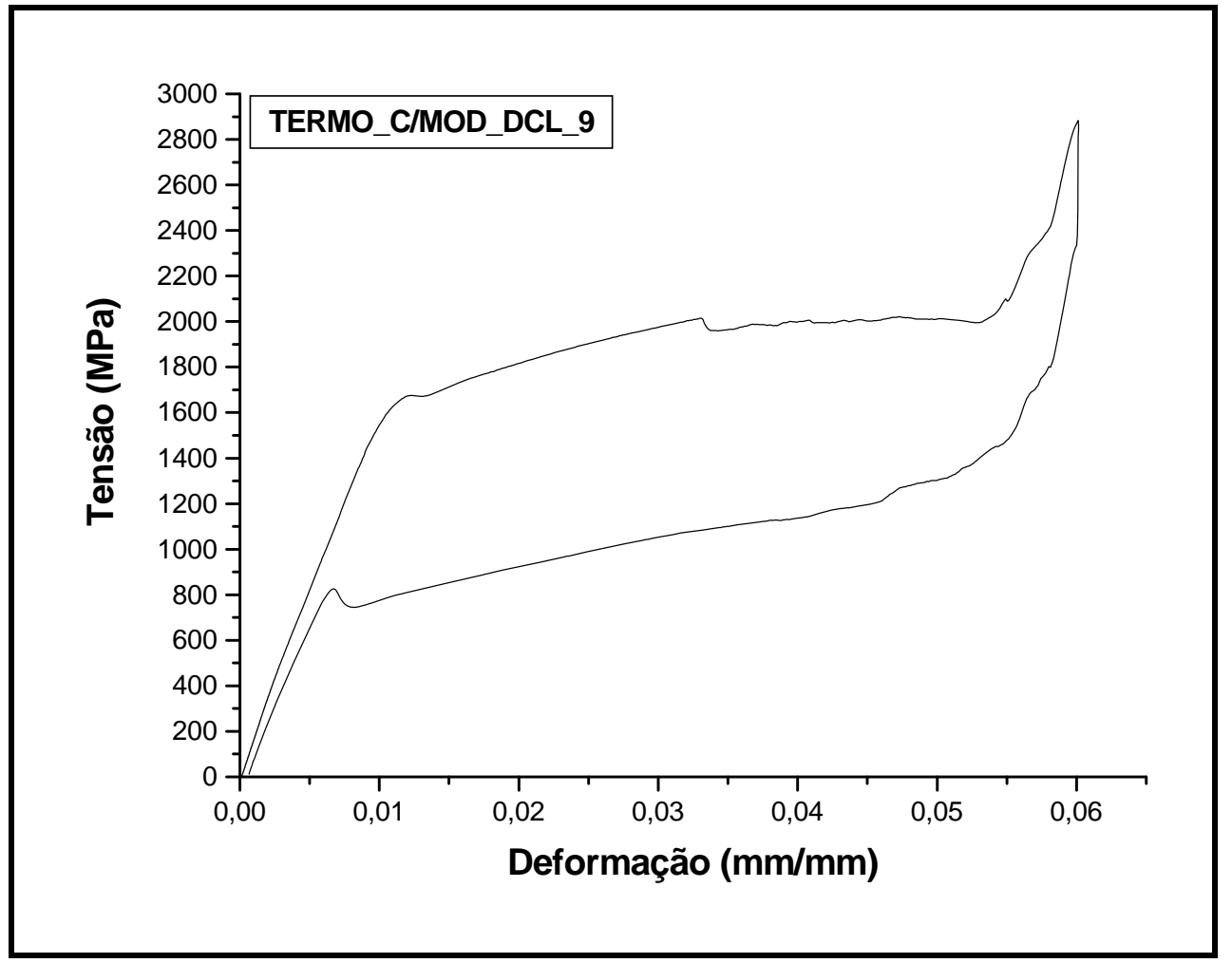

\section{AMOSTRA 10}

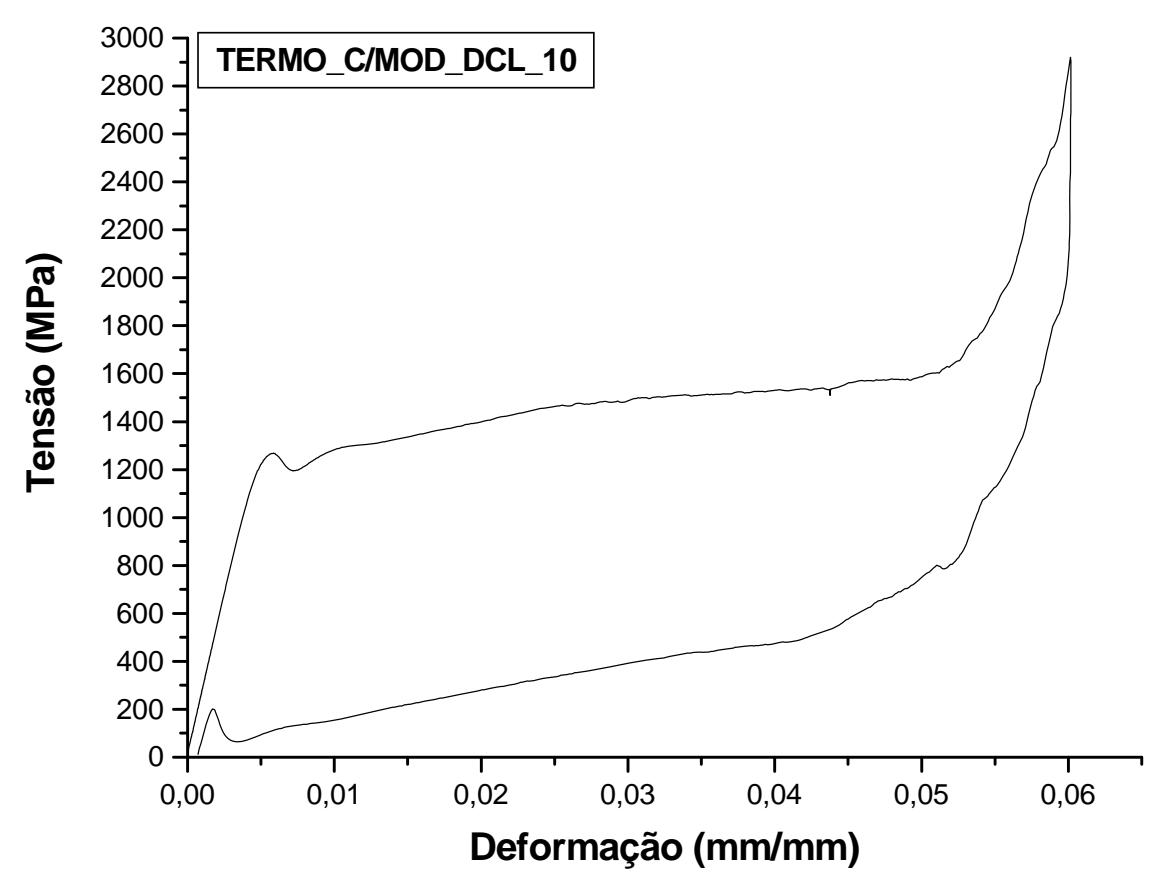

